\title{
HEINONLINE
}

Citation: 86 Minn. L. Rev. 131 2001-2002

Content downloaded/printed from

HeinOnline (http://heinonline.org)

Thu Mar 20 15:37:23 2014

-- Your use of this HeinOnline PDF indicates your acceptance of HeinOnline's Terms and Conditions of the license agreement available at http://heinonline.org/HOL/License

-- The search text of this PDF is generated from uncorrected OCR text.

-- To obtain permission to use this article beyond the scope of your HeinOnline license, please use:

https://www.copyright.com/ccc/basicSearch.do?

\&operation $=$ go\&search Type $=0$

\&lastSearch $=$ simple\&all $=$ on\&titleOrStdNo $=0026-5535$

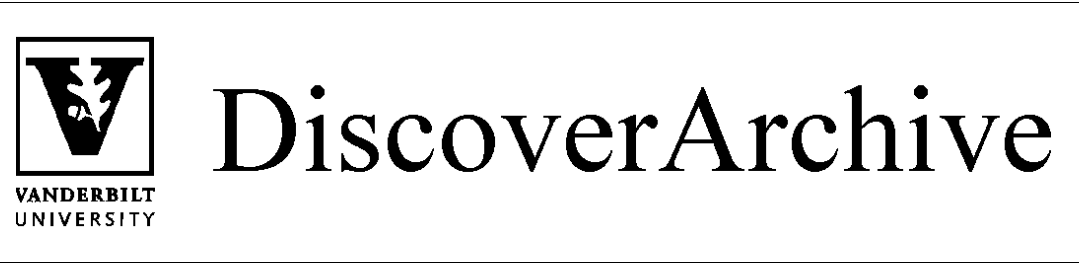

Retrieved from DiscoverArchive,

Vanderbilt University's Institutional Repository

This work was originally published as Paul H. Edelman and Jim Chen, The Most Dangerous Justice Rides Again: Revisiting the Power Pageant of the Justices, 86 Minn. L. Rev. 131 2001-2002. 


\section{The Most Dangerous Justice Rides Again: Revisiting the Power Pageant of the Justices}

\section{Paul H. Edelman† and Jim Chen $\uparrow \dagger$}

I. The Supreme Court at the Crossroads of Power .............132

II. The Power Pageant of the Justices Revisited ...............136

A. The Most Dangerous Justice .............................136

1. Methodology .............................................136

2. Naive Index .........................................140

3. Sophisticated Index $\quad$...................................141

4. Generalized Banzhaf Index ............................143

B. Lynn Baker's Search for the "Median" Justice ............148

1. Baker's Standard Measure ..............................148

2. Baker's Decision Method ..................................150

3. Modified Median Measure ..................................150

C. Let the Games Begin ......................................151

III. The Most Dangerous Justice Rides Again ................153

A. Variations on a Theme by Banzhaf .....................153

1. Naive Index ................................................153

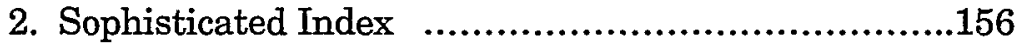

3. Generalized Banzhaf index .............................160

B. Musings on the Meaning of the Median .................161

1. Baker's Standard Measure ..................................162

2. Baker's Decision Method ................................164

3. Modified Median Measure .................................167

C. Handicapping the Power Pageant: A Halftime

Report .......................................................172

D. Indirect Measures of Voting Power ...................176

† Professor of Mathematics and Law, Vanderbilt University <paul.edelman@ law.vanderbilt.edu>.

i† James L. Krusemark Professor of Law, University of Minnesota Law School <chenx064@umn.edu>. Tracey Holmes Donesky, Anita Arockiasamy, and Nicole Narotzky provided very capable research assistance. Daniel A. Farber, Stuart Minor Benjamin, Howard Gillman, Gil Grantmore, and Linda Greenhouse provided helpful comments. Special thanks to Kathleen Chen. 
1. Number of Cases Decided by Particular Coalitions .177

2. Number and Significance of 5-4 Opinions Written by Individual Justices .180

3. Compatibility Measured Indirectly Through

Voting Alignments 189

E. There He Is: The Most Dangerous Justice 192 IV. The Supple in Spirit Shall Inherit the Kingdom of Power 193

A. Mathematical Movement and Mayhem in the Marketplace of Schemes .........................................193

1. Divergence and Congruence .............................193

2. Infant Mortality .............................................195

3. Staying Alive .............................................198

B. The Power Pageant of the Indexes ........................198

1. Madness in Our Methodology ...........................198

2. The Congruence Contest..................................199

3. Feasibility's Fate .........................................203

4. The Niftiness of Naïveté ....................................206

C. The Message in the Median ................................216

1. Predicting the Cumulative Naive Index.................216

2. Predicting the Cumulative Sophisticated Index .......217

3. Predicting the Cumulative Modified Median Measure .............................................218

V. The Permanence of the Power Pageant ......................220

Mathematical Appendix ..........................................223

\section{THE SUPREME COURT AT THE CROSSROADS OF POWER}

Who indeed is the most dangerous member of the Supreme Court? In The Most Dangerous Justice: The Supreme Court at the Bar of Mathematics, ${ }^{1}$ published during 1996 in the Southern California Law Review, we developed a game-theoretic model for assessing differences in voting power among the Jus-

1. Paul H. Edelman \& Jim Chen, The Most Dangerous Justice: The Supreme Court at the Bar of Mathematics, 70 S. CAL. L. REV. 63 (1996) Thereinafter Dangerous Justice]. 
tices. In response to criticism by Professor Lynn A. Baker, ${ }^{2}$ we refined this model in "Duel" Diligence: Second Thoughts About the Supremes as the Sultans of Swing, also published in the Southern California Law Review. ${ }^{3}$

The time has come for a sober second look at voting power on the Supreme Court. The Presidential election of 2000 represented a watershed moment in public awareness of the high court's internal politics. ${ }^{4}$ The Court's prominent role in breaking the electoral deadlock has shaken "the Nation's confidence in the [Justices] as ... impartial guardian[s] of the rule of law." The longest election night in living memory intensified interest in the putatively "conservative' coalition of Chief Justice Rehnquist and Associate Justices O'Connor, Scalia, Kennedy, and Thomas," which decided Bush $v$. Gore and numerous other high-profile cases during the preceding decade. Journalistic attention centered once again on Justices O'Connor and Kennedy, the only Justices not to have signed an opinion in Bush v. Gore and the subject of speculation over the authorship of the per curiam opinion that ended the 2000 Presidential contest. $^{7}$

Surprised and disappointed though voters might have been, sophisticated observers have always understood that the

2. Lynn A. Baker, Interdisciplinary Due Diligence: The Case for Common Sense in the Search for the Swing Justice, 70 S. CAL. L. REv. 187 (1996).

3. Paul H. Edelman \& Jim Chen, "Duel" Diligence: Second Thoughts About the Supremes as the Sultans of Swing, 70 S. CAL. L. REV. 219 (1996) [hereinafter Sultans of Swing].

4. See, e.g., Akhil Reed Amar, Supreme Court: Should We Trust Judges?, L.A. TIMES, Dec. 17, 2000, at M1; Michael W. McConnell, A Muddled Ruling, WALL ST. J., Dec. 14, 2000, at A26; Jeffrey Rosen, Disgrace, NEW REPUBLIC, Dec. 25, 2000, at 18; Evan P. Schultz, Justice Unrobed, LEGAL TIMES, Dec. 18, 2000 , at 70; Herman Schwartz, The God That Failed, THE NATION, Jan. 1, 2001, at 5. See generally SAMUEL ISSACHAROFF, PAMELA S. KARLAN \& RICHARD H. PILDES, WhEN Elections Go BAD: THE LAW OF DEMOCRACY AND THE PRESIDENTIAL ELECTION OF 2000 (2001).

5. See Bush v. Gore, 121 S. Ct. 525, 542 (2000) (Stevens, J., dissenting); cf., e.g., Mitchell v. W.T. Grant Co., 416 U.S. 600, 636 (1974) (Stewart, J., dissenting) (" $[\mathrm{A}]$ basic change in the law upon a ground no firmer than a change in our membership invites the popular misconception that this institution is little different from the two political branches of the Government. No misconception could do more lasting injury to this Court . ..."). But cf. James B. Beam Distilling Co. v. Georgia, 501 U.S. 529, 550 (1991) (O'Connor, J., dissenting) ("[W]hen the Court changes its mind, the law changes with it.").

6. Dangerous Justice, supra note 1 , at 87.

7. See, e.g., Linda Greenhouse, Election Case a Test and a Trauma for Justices, N.Y. TMIES, Feb. 20, 2001, at A1. 
Supreme Court's internal dynamics are inherently political. ${ }^{8}$ "[L]aw, as it is generated by the Supreme Court, is the longterm product of short-term strategic decision making." The politically savvy realize that possession of "high political powers" heightens the value "of strategy and tactics" to each of the Justices and to the Court as an institution. ${ }^{10}$

The 2000 election also represented a milestone in executive and judicial continuity. Since the beginning of October Term 1994-from the midpoint of Bill Clinton's first term to the end of the Clinton presidency-the Supreme Court has experienced no turnover. In honor of the lively interplay between President Clinton's appointments and the Rehnquist Court crafted by earlier Republican administrations, ${ }^{11}$ we may call today's Justices by the collective name of the "Clinton-Rehnquist" Court. Whatever else the Clinton-Rehnquist Court may accomplish before it disbands, it has already achieved exceptional stability in personnel. Frequent turnover in membership has been a Supreme Court tradition. Only one other collection of Justices has remained intact for a stretch exceeding seven Terms. ${ }^{12}$ Indeed, every President except William Harrison, Zachary Taylor, Andrew Johnson, and Jimmy Carter has managed to nominate

8. See generally, e.g., WALTER F. MURPHY, ELEMENTS OF JUDICIAL STRATEGY (1964). (1998).

9. LeE EPSTEIN \& JACK KNIGHT, THE ChotCES Justices MAKE, at xiii

10. Eugene V. Rostow, American Legal Realism and the Sense of the Profession, 34 RockY MTN. L. REv. 123, 142 (1962).

11. Between President Johnson's appointment of Thurgood Marshall in 1967 and President Clinton's appointment of Ruth Bader Ginsburg in 1993, Republican Presidents appointed an unbroken string of two Chief Justices and nine Associate Justices. See The Supreme Court Historical Society, at http://www.supremecourthistory.org/fp/courtlist.htm (last visited Oct. 5, 2001). We do not mean to suggest, of course, that losing an entire generation of Supreme Court appointments by Democratic Presidents had any measurable impact on the Court's jurisprudence. See Suzanna Sherry, All the Supreme Court Really Needs to Know It Learned from the Warren Court, 50 VAND. L. REV. 459 (1997) (arguing that the current Supreme Court is no more conservative than the Warren Court).

12. Only three times have gaps as long as six years intervened between Supreme Court appointments. No Justices joined the Court between John Paul Stevens in 1975 and Sandra Day O'Connor in 1981. Louis D. Brandeis and John $\mathrm{H}$. Clarke were appointed in 1916; Pierce Butler and George Sutherland joined the Court in 1922. The longest gap, twelve years, took place after the appointments of Joseph Story and Gabriel Duvall in 1811. No new appointments to a seven-Justice Court occurred until Smith Thompson was appointed in 1823. See The Supreme Court Historical Society, at http://www.supremecourthistory.org/fp/courtlist.htm (last visited Oct. 5, 2001). 
at least one Supreme Court Justice. ${ }^{13}$ We therefore have a unique opportunity to test hypotheses about relative voting power among the Justices. The decisions delivered during the seven Terms since Stephen Breyer became the 108th Justice permit a full reconsideration of previously outlined models for measuring voting power on the Supreme Court.

True to our mission "to infuse mathematical rigor into the study of Supreme Court voting,"14 we now revisit our theories in light of events since 1996. Part II of this Article restates, in abbreviated form, three models of voting power that we developed in 1996. It also presents three variants of an alternative model proposed by Professor Lynn Baker of the University of Texas School of Law. Her model differs from ours most dramatically in its assumption that there is a "median" voter on the Supreme Court. Under Professor Baker's view of the Court, every case can be aligned along a single ideological dimension, and the Justice whose ideology falls in the fourth position from either extreme will cast a decisive "swing" vote.

Taking full advantage of the additional five Supreme Court Terms now available to us, Part III of this Article uses the full set of cases decided by the Clinton-Rehnquist Court to test six separate models of judicial voting power. We cast serious doubt on one of our own measures and two of Professor Baker's. Our most sophisticated model, designed to emulate the ebb and flow of power on the Court, loses its accuracy over time and supplies no meaningful information over the long run. The artifice of inferring hypothetically feasible five-Justice coalitions from actually observed coalitions of any size eventually generates so much information that it blurs power differences among the Justices. One of Professor Baker's models attributes too much power to unanimous decisions, which reveal nothing about the Court's coalitional dynamics. The other exposes the distorting impact of the Court's docket on Professor Baker's analysis. From the remaining models, we stage anew the Power Pageant

13. Harrison and Taylor had the excuse of dying in office, though James Garfield managed an appointment (Stanley Matthews) before an assassin's bullet truncated his administration. Congress deliberately shrank the membership of the Court during Johnson's administration to prevent him from appointing any Justices. Carter could blame only bad luck for his Supreme Court shutout. See generally THE OXFORD COMPANION TO THE SUPREME COURT OF THE UNTTED STATES 775 (Kermit L. Hall ed., 1992) (describing the Judiciary Acts of 1866 and 1869); id. at 972-77 (listing Supreme Court appointments by presidential term).

14. Sultans of Swing, supra note 3, at 238. 
of the Justices and crown the Most Dangerous Justice of the Clinton-Rehnquist Court.

Part IV weighs the relative merits of the three most informative models of Supreme Court voting power. We conclude that three different models measure distinct aspects of judicial power. A relatively simple model based on the number of distinct five-Justice coalitions provides the most straightforward gauge of the ability to cast a decisive, tie-breaking vote. A more sophisticated model measures the degree with which a Justice can credibly threaten to abandon a tenuous five-Justice coalition. Finally, the rudimentary method of counting the number of distinct winning coalitions measures each Justice's marginal propensity to win. The predictive powers of these measures ultimately justify the use of game theory to gauge voting power on the Supreme Court.

\section{THE POWER PAGEANT OF THE JUSTICES REVISITED}

\section{A. The Most Dangerous Justice}

This project grew out of frustration with the casual nature of knowledge about voting power on the Supreme Court. Generally speaking, "[j]udicial strategy is not much considered by legal scholars." ${ }^{2}$ What literature there is often adopts an informal approach. Somewhere in the anecdotal fog between portrayals of the Justices as active strategists and as passive swing voters, we endeavored to craft a mathematically sound model for measuring the relative strength of each Supreme Court Justice. ${ }^{16}$ The keys to the mystery of judicial power, we hoped, lay in mastery of the mathematics underlying the Justices' votes.

\section{Methodology}

"[T]he true test of voting power is the ability to cast a tiebreaking, or 'critical,' vote."17 In 1966, John H. Banzhaf III developed an index for analyzing voting systems by this criterion. ${ }^{18}$ No less an authority than the Supreme Court has ex-

15. Frank B. Cross, The Justices of Strategy, 48 DUkE L.J. 511, 511 (1998) (reviewing EPSTEIN \& KNIGHT, supra note 9).

16. See Dangerous Justice, supra note 1, at 64-66.

17. Whitcomb v. Chavis, 403 U.S. 124, 145 n.23 (1971).

18. See John F. Banzhaf III, Weighted Voting Doesn't Work: A Mathematical Analysis, 19 RUTGERS L. REV. 317 (1965). 
plained the Banzhaf index:

In a population of $n$ voters, where each voter has a choice between two alternatives (candidates), there are $2^{n}$ possible voting combinations. For example, with a population of three voters, A, B, and C, and two candidates, $\mathrm{X}$ and $\mathrm{Y}$, there are eight combinations:

$\mathrm{ABC}$

$\# 1 . \mathrm{XXX}$

\#2. XXY

\#3. XYX

\#4. XYY

\#5. YXX

\#6. YXY

$\# 7$. YXX

\#8. YYY

$\ldots$ In th[is] population of three voters...., any voter can cast a critical vote in four situations; in the other four situations, the vote is not critical since it cannot change the outcome of the election. For example, $\mathrm{C}$ can cast a tie-breaking vote only in situations $3,4,5$, and 6 . The number of combinations in which a voter can cast a tie-breaking vote is

$$
2 \cdot \frac{(\mathrm{n}-1) !}{((\mathrm{n}-1) / 2) ! \cdot((\mathrm{n}-1) / 2) !}
$$

where $n$ is the number of voters. Dividing this result (critical votes) by $2^{\mathrm{n}}$ (possible combinations), one arrives at that fraction of possible combinations in which a voter can cast a critical vote. This is ... [Banzhafs] measure of voting power.

One skeptical Justice has quipped that "[ $t]$ he only relevant difference between ... the elementary probability theory [developed by] Professor Banzhaf" and "the elementary arithmetic" which characterizes legal applications of Banzhaf's work "is that calculations in the [former] field cannot be done on one's fingers." ${ }^{20}$ The Banzhaf index nevertheless enjoys broad legal currency. The equitable reallocation of voting power among member-states holds the key to eastward expansion of the European Union. ${ }^{21}$ A generation ago, scholars subjected Canadian constitutional reform to a similar exercise in game theory. $^{22}$ Closer to home, work by Banzhaf and other game theo-

19. Whitcomb, 403 U.S. at 145 n.23.

20. Id. at $168 \mathrm{n} .2$ (separate opinion of Harlan, J.).

21. See The Many Tricky Ways of Widening Europe, ECONOMIST, Dec. 9, 2000, at 55. See generally, e.g., Council Decision No. 98/260, 1998 O.J. (L 121) (outlining conditions for Poland's accession to the European Union).

22. See D.R. Miller, A Shapley Value Analysis of the Proposed Canadian Constitutional Amendment Scheme, 6 CAN. J. POL. ScI. 140 (1973). 
rists has informed the resolution of American voting rights cases $^{23}$ and even illuminated the equities of the electoral college. ${ }^{24}$

Compared with other institutions, the Supreme Court has received little attention from students of relative voting strength. $^{25}$ Our 1996 articles sought to transform the Court from a mere consumer of the Banzhaf index into an apt subject for its application. We began with the simple assumption "that the only time that an individual Justice's vote matters is when he [or she] is in a coalition of exactly five Justices."26 We repeat: The true test of voting power lies in the ability to break ties. Because "the defection of any one Justice would make losers of the other four," we initially assumed that each Justice should be regarded "as much a 'swing voter' as any of the others in this fragile coalition." 27

These assumptions suggest that voting power may be measured simply by counting the number of unique five-Justice coalitions that appear over some period and dividing by five the number of times each Justice appears in coalitions of this sort. $^{28}$ A tally of five-Justice coalitions in each Supreme Court Term can be derived from the Harvard Law Review's annual list of $5-4$ decisions in the previous Term, ${ }^{29}$ augmented by

23. See Holder v. Hall, 512 U.S. 874, 925 n.23 (1994) (Thomas, J., concurring in the judgment) (citing John F. Banzhaf III, Multi-Member Electoral Districts-Do They Violate the "One Man, One Vote" Principle?, 75 Yale L.J. 1309 (1966)); Whitcomb, 403 U.S. at 146 n.23; id. at 168-70 (separate opinion of Harlan, J.); Kilgarlin v. Hill, 386 U.S. 120, 125 n.3 (1967) (per curiam); see also Bd. of Estimate v. Morris, 489 U.S. 688, 697-99 (1989) (rejecting the "Banzhaf Index" as applied to a borough-by-borough voting scheme within New York City's municipal government); id. at 704 (Blackmun, J., concurring in part and concurring in the judgment) ("T ... suspect the Court is correct in rejecting the Banzhaf Index ....").

24. See Morris, 489 U.S. at 607-99; Irwin Mann \& L.S. Shapley, The A Priori Voting Strength of the Electoral College, in GAME THEORY AND RELATED APPROACHES TO SOCIAL BEHAVIOR 151-63 (Martin Shubik ed., 1964); John H. Banzhaf III, One Man, 3.312 Votes: A Mathematical Analysis of the Electoral College, 13 VILL. L. REV. 304 (1968); Guillermo Owen, Evaluation of a Presidential Election Game, 69 AM. POL. SCI. REv. 947 (1975).

25. See Baker, supra note 2, at 189; see also id. at 200 (explaining in greater detail "why aficionados of the Shapley-Shubik and Banzhaf Indexes have shown little interest in studying the Supreme Court").

26. Dangerous Justice, supra note 1, at 66.

27. Id.

28. See id. at 71-72.

29. See, e.g., The Supreme Court, 1994 Term-Leading Cases, 109 HARv. L. REv. 111, 343 (1995) [hereinafter 1994 Harvard Survey]. 
deeper legal analysis of decisions that do not fit Harvard's relatively rigid criteria. ${ }^{30}$ Harvard requires that five Justices disagree with four on outcome as well as reasoning. By contrast, we will recognize a five-member coalition as long as exactly five Justices join the same opinion, regardless of the Court's overall alignment on the disposition of a case. Neither Harvard nor we regard "two Justices as having agreed if they did not join the same opinion, even if they agreed in the result of the case and wrote separate opinions revealing very little philosophical disagreement." 31 Opinions, after all, represent "the maturing of collective [judicial] thought" and consequently outweigh mere agreement in result as a measure of the Justices' propensity to cooperate. ${ }^{32}$ We therefore treat the increasingly fashionable opinion concurring in the judgment merely as another species of dissent. ${ }^{33}$

We should clarify another aspect of our methodology. We have consciously chosen to count only the number of different coalitions-whether observed, inferred, or theoretical-and to ignore the number of cases decided by a particular coalition. We believe that "[u]seful distinctions among individual Justices' voting power... depend less on the number of times a particular coalition is successful and more on the number of different coalitions that each individual Justice is ideologically able to join."34 One could, of course, incorporate the frequency of coalitions in a measurement of voting power on the Supreme Court. Weighing each five-Justice coalition according to the likelihood of its occurrence could yield a stochastic measure of Supreme Court voting power. ${ }^{35}$ That methodology, however, presents severe technical hurdles whose resolution would require an altogether different paper.

30. See Dangerous Justice, supra note 1, at 69-70 \& n.32, 71 \& n.45.

31. 1994 Harvard Survey, supra note 29, at 342 n.f; accord Dangerous Justice, supra note 1 , at 79-80.

32. Henry M. Hart, Jr., The Supreme Court, 1958 Term-Foreword: The Time Chart of the Justices, 73 HARV. L. REV. 84, 100 (1959).

33. See Robert W. Bennett, A Dissent on Dissent, 74 JUDICATURE 255 (1990).

34. Dangerous Justice, supra note 1, at 69.

35. See, e.g., Baker, supra note 2, at 202; Richard G. Wilkins et al., Supreme Court Voting Behavior: 1994 Term, 23 HASTINGS CoNST. L.Q. 1, 27, 43-46 (1995); cf. Paul H. Edelman \& Suzanna Sherry, All or Nothing: Explaining the Size of Supreme Court Majorities, 78 N.C. L. REv. 1225, 1226 (2000) (exploring the frequency of coalitions of specific sizes in the Supreme Court's record of decisions). 
Indeed, that paper has already been written. Arthur Frank and Lloyd Shapley applied the Shapley-Shubik index to October Term 1977. ${ }^{36}$ In our initial 1996 article, we reviewed and rejected Frank and Shapley's methodology. ${ }^{37}$ Among other reasons, their application of the Shapley-Shubik index contains "an inherent additive measure ... which is not present in the Banzhaf index."38 "[T]he Shapley-Shubik index depends on equiprobable permutations of $N$, whereas the Banzhaf index depends on equiprobable combinations." ${ }^{39}$ Our chief critic, who frequently applies the Shapley-Shubik index in her own work, ${ }^{40}$ acknowledges the difficulty in translating information derived from observed combinations of Justices into ideologically arrayed permutations containing a "single pivot." 11

\section{Naive Index}

From these basic assumptions, we derived what we called our "naive index" of voting power. "[O]ver a Term or a stretch of Terms, an individual Justice's voting power may be expressed as the percentage of the time that the Justice [takes part] in a five-member coalition, less the eighty percent of the voting power attributable to the four other members of each coalition." ${ }^{42}$ For example, in October Term 1994, Chief Justice Rehnquist appeared in seven of eleven five-Justice coalitions. ${ }^{43}$ For him and for each of the Associate Justices, "we compute[d] the number of times that [each] Justice appeared in a fiveJustice coalition, divided by the total number of five-Justice coalitions in the relevant time period, and multiplied by 20 (in

36. See ARTHUR Q. FRANK \& LLOYD SHAPLEY, THE DISTRIBUTION OF POWER IN THE U.S. SUPREME COURT (A RAND Note, N-1735-NSF, RAND Corp. 1981). See generally L. S. Shapley \& Martin Shubik, A Method for Evaluating the Distribution of Power in a Committee System, 48 AM. POL. SCI. REV. 787 (1954); AIAN D. TAYlOR, MATHEMATICS AND POLITICS: STRATEGY, VOTING, POWER AND PROOF 65-71 (1995) (explaining the Shapley-Shubik index).

37. See Dangerous Justice, supra note 1 , at 76-80.

38. Martin Shubik, Game Theory In THE Soclat Sciences: ConcePtS AND SOLUTIONS 204 (1982).

39. Id. at 203-04.

40. See Lynn A. Baker, Direct Democracy and Discrimination: A Public Choice Perspective, 67 CHI.-KENT L. REV. 707, 730 (1991); Lynn A. Baker, Federalism: The Argument from Article V, 13 GA. ST. U. L. REV. 923, 927-32 (1997); Lynn A. Baker \& Samuel H. Dinkin, The Senate: An Institution Whose Time Has Gone?, 13 J.L. \& POL. 21, 24-29 (1997).

41. Baker, supra note 2, at 191-92.

42. Dangerous Justice, supra note 1 , at 66.

43. See id. at 70-71. 
order to reflect the assumption that each Justice in a fivemember coalition wields 20 percent of the Court's power). ${ }^{, 44}$ "[M]ultiplying the [resulting] power index by nine" yields a judicial quotient (JQ) on a scale where 100 expresses "exactly the amount of power that [an average Justice] should expect to wield. ${ }^{, 45} \mathrm{JQ}$ is to judicial power as IQ is to mental aptitude. We calculated that Chief Justice Rehnquist enjoyed a naive power index of 12.7 during the 1994 Term and a JQ of 114, slightly above benchmarks of 11.1 and 100 .

There are, however, slight discrepancies between our 1996 articles and this renewed look at the Supreme Court. After reexamining the 1994 Term, we now calculate that Chief Justice Rehnquist scored 13.8 on the naive power index, equivalent to a $\mathrm{JQ}$ of 125. Given the larger temporal scope of this study, we conducted de novo analysis of each Term's cases before subjecting them anew to our measures of voting power. We found a slightly larger number of coalitions in each of the 1994 and 1995 Terms. ${ }^{46}$ We believe that minor variations in the mechanical application of our indexes do not impugn their underlying theoretical integrity.

\section{Sophisticated Index}

Our second index arises from a crucial twist on Banzhafs theme: ideological difference. In refining our model of judicial voting, we abandoned "the traditional game-theoretic assumption that all potential coalitions among Supreme Court Justices are equally likely."47 In light of the Justices' ideological propensities and observed voting behavior, we assumed that certain coalitions attracting a precise combination of Justices and excluding all others will not emerge. ${ }^{48}$ The Shapley-Shubik model's contrary assumption-that Justices are unconstrained in their ability to form, break, and reassemble winning blocscannot withstand this realistic assessment of ideological di-

44. Id. at 71-72.

45. Id. at 72-73.

46. We originally found seventy-four coalitions in each of these Terms and a total of 108 coalitions in these two Terms combined. See id. at 83. Closer scrutiny revealed seventy-nine coalitions in October Term 1994, seventy-six coalitions in October Term 1995, and a total of 113 coalitions in the two Terms combined.

47. Id. at 68 ; see also $i d$. at 67 ("We deliberately reject [those] .... applications of game theory [that] assume that coalitions may freely form within any given population of voters.").

48. See id. at 67-68. 
vides within the Court. ${ }^{49}$

If in fact "some blocs" of Justices "simply will not form,"s0 then we cannot assume "that every Justice in a five-Justice [coalition] is equally likely to defect." "El "Each 5-4 decision," after all, represents two distinct coalitions-one "embod[ying] a set of legal propositions with which all members of the prevailing ... majority agree" and another hoping to attract a fifth vote from what is, for the moment, a fragile winning alliance. ${ }^{52}$ In order to represent a credible threat to abandon the winning coalition, a defecting Justice must demonstrate a certain "degree of ideological independence" from the four remaining members of that coalition. ${ }^{53}$ In other words, the rump fourJustice minority left in the wake of the would-be defector must itself be "feasible"-in the sense that this incipient coalition would adopt at least one unique set of legal propositions "to the complete exclusion of the other Justices." "The hallmark of every feasible coalition is the existence of "some legal proposition on which [those] Justices and only [those Justices] would agree." If If those "four Justices ... do not themselves form a feasible coalition, this is a reliable signal that the would-be defector is too ideologically bound to the other four" and that a "threat by this Justice to defect would not be credible."56 A Justice who "has not demonstrated sufficient ideological independence to abandon the rest of the coalition" ought not be assigned the voting power otherwise attributable to his or her contribution to a five-Justice coalition. ${ }^{57}$

A more sophisticated measure of voting power on the Supreme Court therefore arises from an acknowledgement of the limits on the number of feasible coalitions that a group of ideologically diverse Justices can attain. By normalizing the results of the naive survey to account for nonfeasible coalitions, we derived what we now call the "sophisticated index" of voting

49. See Saul Brenner, The Shapley-Shubik Power Index and Supreme Court Behavior, 15 JURIMETRICS J. 194, 198 (1975); Glendon Schubert, The Power of Organized Minorities in a Small Group, 9 ADMIN. SCI. Q. 133, 142 (1964).

50. Dangerous Justice, supra note 1 , at 68.

51. Id. at 73.

52. Id.

53. Id.

54. Id. at 82 (emphasis deleted).

55. Id.

56. Id. at 83 .

57. Id. 
power among the Justices. Though implicit in our 1996 articles, this index was never explicitly computed. We now include it in this fresh look at Supreme Court voting power.

\section{Generalized Banzhaf Index}

One final methodological challenge remains. In the short run, measuring feasibility through direct observation can be frustrating. For any five-Justice majority, we must test as many as five lesser-included coalitions in order to determine which four-Justice alliances are feasible. Consider the notorious conservative bloc of Chief Justice Rehnquist and Justices O'Connor, Scalia, Kennedy, and Thomas. Assessing whether Chief Justice Rehnquist is a credible threat to defect would require either (1) finding a corresponding coalition consisting solely of Justices O'Connor, Scalia, Kennedy, and Thomas, or (2) being confident that the failure to observe this particular four-Justice coalition over a given period of time provides meaningful evidence of the Chief Justice's inability to abandon these four colleagues. When the operative time frame is a single Supreme Court Term, a theoretically feasible rump coalition may not appear. The corresponding Justice then receives no credit for what would otherwise be his or her share of a winning five-Justice majority's voting power. For this reason, single-Term applications of our sophisticated index are often studded with zero ratings for some Justices.

Although we anticipated that a group of ideologically distinct Justices would eventually exhaust its capacity to cooperate, we did not expect that any single Term would permit a meaningful test of this assumption. The Court now decides scarcely half of its traditional "one hundred fifty cases per year." The 129 opinions handed down during the 1990 Term dwindled to a mere 84 by the 1999 Term. $^{59}$ (During the 2000

58. See Peter L. Strauss, One Hundred Fifty Cases Per Year: Some Implications of the Supreme Court's Limited Resources for Judicial Review of Agency Action, 87 COLUM. L. REV. 1093 (1987). See generally LEE EPSTEIN ET AL., THE SUPREME COURT COMPENDIUM: DATA, DECISIONS AND DEVELOPMENTS 84-85 (2d ed. 1996) (reporting that the Court decided roughly 150 cases by full opinion throughout the presidency of Franklin Roosevelt and again during the 1970s and 1980s); Robert Post, The Supreme Court Opinion as Institutional Practice: Dissent, Legal Scholarship, and Decisionmaking in the Taft Court, 85 MINN. L. REV. 1267, 1279-80 (2001) (tracing the contraction of the Supreme Court's docket from a peak of 231 full opinions in the 1924 Term to eighty-nine in 1994).

59. See The Supreme Court, 1999 Term-Leading Cases, 114 HARV. L. REv. 179, 402 tbl.I (2000) [hereinafter 1999 Harvard Survey]. 
Term, the docket rebounded by the grand total of one case). The decline in the Court's argument calendar cannot be attributed to a lack of interest in the country's highest legal tribunal. In two of the Terms since 1994, the Justices disposed of more cases than in any other Term since the Harvard Law Review began compiling Supreme Court statistics during the 1948 Term. $^{60}$ In the 1994 Term, the Court disposed of 7132 cases. ${ }^{61}$ The 1998 Term nearly matched this level of activity with a docket of 7015 cases. ${ }^{62}$

Marked by its "incredibly shrinking" argument calendar, the Clinton-Rehnquist Court has arguably established no defining ideology more salient than institutional inaction. ${ }^{63}$ After the fashion of the situation comedy Seinfeld, it is a Court about nothing. ${ }^{64}$ A single Term of roughly eighty cases can scarcely illuminate the Court's ideological deep structure. As long as the Court's caseload contains a steady stream of "peewee" controversies over tax, Indian, and patent law, ${ }^{65}$ we cannot surmise that the Justices are covering more political ground through a smaller but more carefully filtered set of cases. ${ }^{66}$

Let us speak as concretely as possible. On a Court of nine Justices, 512 unique coalitions are possible. That total is simply 2 . (Once again "we adopt the mathematically convenient, albeit legally nonsensical, convention that the empty coalition is possible." $)^{67}$ Out of 512 possible coalitions, 126-or $9 ! /(4 ! \cdot 5 !)$-represent winning coalitions of exactly five Justices. ${ }^{68}$ We assume that a Court whose members hold divergent

60. See The Supreme Court, 1998 Term-Leading Cases, 113 HaRV. L. REV. 200, 406 \& n.h (1999) [hereinafter 1998 Harvard Survey].

61. See 1994 Harvard Survey, supra note 29, at 344 tbl.II.

62. See 1998 Harvard Survey, supra note 60, at 406 tbl.II.

63. David M. O'Brien, Join-3 Votes, the Rule of Four, the Cert. Pool, and the Supreme Court's Shrinking Plenary Docket, 13 J.L. \& PoL. 779, 779 (1997).

64. Cf. Mark A. Graber, The Clintonification of American Law: Abortion, Welfare, and Liberal Constitutional Theory, 58 OHIO ST. L.J. 731 (1997) (accusing the federal judiciary of abandoning an earlier era's constitutional commitment to welfare rights in favor of a "Clintonified" defense of abortion).

65. BOB WOODWARD \& SCOTT ARMSTRONG, THE BRETHREN: INSIDE THE SUPREME COURT 128 (1979) (quoting Justice John Marshall Harlan); accord Ronald J. Krotoszynski, Jr., Cohen v. California: "Inconsequential" Cases and Larger Principles, 74 TEX. L. REV. 1251, 1255 (1996).

66. Cf. Arthur D. Hellman, The Shrunken Docket of the Rehnquist Court, 1996 SUP. CT. REv. 403, 431-38 (exploring this very possibility).

67. Dangerous Justice, supra note 1 , at 83.

68. See id. at 68 n.26. The number of coalitions-or "combinations," in mathematical convention-consisting of exactly $c$ Justices out of a Court of $n$ members can be expressed through the following formula: 
ideological convictions and vote honestly according to those differences will never form all 126 five-Justice coalitions, let alone all 512 possible coalitions. Our 1996 articles, based as they were on the 1994 and 1995 Terms, operated on too small a sample of cases to test this assumption directly. Our initial survey of those Terms revealed only seventy-four actual coalitions in each Term, "ranging from single dissents to the grand coalition of all Justices in a unanimous Court," and a total of 108 unique, actually observed coalitions in the two Terms combined. ${ }^{69}$

Time has borne out our suspicions. Even after seven Terms, the Justices have not approached the theoretical limits on the number of coalitions they may form. The number of observed coalitions is growing slowly. This holds true for fiveJustice coalitions, all majority coalitions, coalitions consisting of four or more Justices, and all coalitions:

$$
\stackrel{\text { c! }}{(\mathrm{n}-\mathrm{c}) !}
$$

69. Id. at 83. As noted earlier, we have since recalibrated the number of observed coalitions at seventy-nine for the $1994 \mathrm{Term}$, seventy-six for the 1995 Term, and 113 for the two Terms combined. See supra note 46 and accompanying text; see also infra p. 146 tbl.1. 
Table 1: Number of Observed Coalitions

\begin{tabular}{||c|c|c|c|c||}
\hline $\begin{array}{c}\text { Supreme } \\
\text { Court Term(s) }\end{array}$ & $\begin{array}{c}\text { 5-Justice } \\
\text { coalitions }\end{array}$ & $\begin{array}{c}\text { All } \\
\text { majority } \\
\text { coalitions }\end{array}$ & $\begin{array}{c}\text { Coalitions } \geq \\
\text { 4 Justices }\end{array}$ & $\begin{array}{c}\text { All } \\
\text { coalitions }\end{array}$ \\
\hline OT 1994 & 13 & 36 & 47 & Limit: 512 \\
\hline $1994-95$ & 17 & 51 & 65 & 79 \\
\hline $1994-96$ & 22 & 62 & 82 & 113 \\
\hline $1994-97$ & 27 & 76 & 103 & 137 \\
\hline $1994-98$ & 30 & 84 & 114 & 170 \\
\hline $1994-99$ & 35 & 90 & 126 & 198 \\
\hline $1994-2000$ & 37 & 95 & 133 & 209 \\
\hline
\end{tabular}

To simplify the analysis, consider only the trend in fiveJustice coalitions. (This narrow focus would suffice for purposes of our naive index. Growth in the number of four-Justice coalitions is pertinent to our sophisticated index, and the number of all coalitions, especially those that achieve a majority, drives our generalized Banzhaf index.) From October Term 1994 to October Term 2000, the number of distinct five-Justice coalitions has risen from thirteen to thirty-seven. In no year did the cumulative number of observed five-Justice coalitions grow by more than five. Although the sitting Court has maintained its personnel for seven Terms, it has yet to reveal anything close to the theoretical number of different five-Justice coalitions. Thirty-seven is substantially less than 126, and even under generous assumptions, the number of observed fiveJustice coalitions will not approach the theoretical limit for another fifteen years. Perhaps greater diversity in the Court's docket, combined with ideological evolution on the part of individual Justices, will eventually allow any group of nine jurists to exhaust their cooperative potential. The actuarial expectation of such an event, however, is forbiddingly low. "In the long run we [really] are all dead." ${ }^{70}$

To bridge the gap between the low number of actually observed coalitions and the greater but still delimited number of

70. JOHN MAYNARD KEYNES, A TRACT ON MONETARY REFORM 80 (1923). 
feasible coalitions, we devised an artifice for inferring feasibility from a limited number of decisions. To augment the feasible coalitions used in the computation of our sophisticated index, we derived a fuller "set of feasible coalitions from the intersection of any collection of actual coalitions" observed "during a Term" or over a series of Terms. ${ }^{71}$ The existence of a feasible four-Justice coalition, for example, means "that there is some legal proposition on which these four Justices and only these four would agree."72 Our original computations yielded 308 feasible coalitions in the 1994 Term, 228 in the 1995 Term, and 398 in the two Terms combined. ${ }^{73}$ We used this set of inferred coalitions to compute our final and most elaborate measure of Supreme Court power, which we called a generalized Banzhaf index.

Two six-Justice coalitions from the 1994 Term demonstrate how our method could and did predict the emergence of feasible but previously unobserved coalitions. ${ }^{74}$ Chief Justice Rehnquist and Justices O'Connor, Kennedy, Souter, Ginsburg, and Breyer agreed long enough to decide a substantial portion of Witte $v$. United States. ${ }^{75}$ A second six-Justice coalition, consisting of Justices Stevens, O'Connor, Kennedy, Souter, Ginsburg, and Breyer, decided four cases during that Term. ${ }^{76}$ The five-Justice alliance that we derived from the intersection of these sixJustice blocs never actually coalesced during the 1994 Term. During the 1995 Term, however, this coalition-namely, Justices O'Connor, Kennedy, Souter, Ginsburg, and Breyerfulfilled its promise of feasibility when it delivered the crucial five votes that decided Gasperini $v$. Center for Humanities, Inc. ${ }^{77}$

At least on the scale of a single Supreme Court Term, the difference between the naive and generalized Banzhaf indexes can be dramatic. In October Term 1995, for instance, Justice Ginsburg tied for third in the naive measure, registering a

71. Dangerous Justice, supra note 1 , at 82.

72. Id.

73. See id. at 83.

74. This example comes from Sultans of Swing, supra note 3, at 223-24.

75. 515 U.S. 389 (1995) (O’Connor, J.).

76. See Babbitt v. Sweet Home Chapter of Cmtys. for a Great Or., 515 U.S. 687 (1995) (Stevens, J.); McIntyre v. Ohio Elections Comm'n, 514 U.S. 334 (1995) (Stevens, J.); United States v. Nat'1 Treasury Employees Union, 513 U.S. 454 (1995) (Stevens, J.); O’Neal v. McAninch, 513 U.S. 432 (1995) (Breyer, J.).

77. 518 U.S. 415 (1996) (Ginsburg, J.). 
power index of 12.5 and a JQ of $113^{78}$ After we took full account of feasible coalitions, including those inferred from coalitions that actually materialized during that Term, our generalized Banzhaf index registered 14.9 for Justice Ginsburg. ${ }^{79}$ With a lead of almost two percentage points over her closest competitor, Justice Ginsburg enjoyed thirty-four percent more power than she would expect on a Court of equally flexible Justices. $^{80}$

In our renewed look at the Power Pageant of the Justices, Chief Justice Rehnquist experienced an even more dramatic transformation during October Term 1995. Rated an insipid 7.5 on the naive index (with a corresponding JQ of sixty-eight), the Chief Justice gained forty points in JQ and rose to a respectable 12.0 under the generalized Banzhaf index.

In sum, we have proposed three ways of measuring Supreme Court voting power: (1) a naive index based solely on five-Justice coalitions, (2) a sophisticated index accounting for the credibility of defection on the part of each member of each five-Justice coalition, and (3) a generalized Banzhaf index enhancing this crucial notion of feasibility by calculating the intersection of actual observed coalitions. In Part III of this Article, we reexamine all of these indexes.

\section{B. LYNN BAKER'S SEARCH FOR THE "MEDIAN" JUSTICE}

\section{Baker's Standard Measure}

If indeed "joining issue is the sincerest form of flattery,"81 then Professor Lynn Baker has lionized our analysis by proposing an alternative measure of Supreme Court voting power. Professor Baker effectively equates "the Court's 'most powerful" Justice with its "median Justice."82 Game theory, so central to our analysis, plays a very limited role in Professor Baker's approach. At best, she argues, "game theory can ... confirm our intuitions: (1) that one of the Justices in [any

78. See Dangerous Justice, supra note 1 , at 72.

79. See id. at 84 .

80. See id. According to our revised figures for October Term 1995, the generalized Banzhaf index registered 13.6 for Justice Ginsburg, a more modest improvement over her naive index. The twenty-three percent margin over her expected voting power nevertheless gave Justice Ginsburg the largest single share of power among the Justices that Term.

81. Baker, supra note 2, at $187 \mathrm{n} . *$.

82. Id. at 190. 
given] majority was the true pivot or median Justice in the case, and (2) that each of the Justices in the majority is equally likely to have been that swing voter." 83

Even a cursory examination of that statement reveals how fundamentally Professor Baker disagrees with our project. First, ours emphatically is not a search for the "median" Justice. Never having equated "the median Justice" with "the Most Dangerous Justice," we are "ultimately concerned with each Justice's ability to deliver a 'swing' vote, not with a Justice's distance from the Court's ideological core." $\$ 4$ Mindful of the Justices' propensity to form "revocable groupings" of constantly shifting coalitions, ${ }^{85}$ we assume that the Justices must "identify issues along multiple dimensions and... balance their jurisprudential and political preferences along several axes." By contrast, Professor Baker "imagines that the Justices are arrayed along" a single dimension. ${ }^{87}$

Second, Professor Baker's assumption "that each of the Justices in [a] majority is equally likely to have been [the] swing voter" squarely contradicts our feasibility analysis. ${ }^{88}$ It cannot coexist with either our sophisticated index or our generalized Banzhaf index.

Professor Baker's proposed alternative, at the very least, does have the virtue of simplicity. ${ }^{89}$ What she touts as "[t]he most obvious and sensible approach" consists solely of "examin [ing] all of the Court's decisions during [a] relevant Term, and simply ... count[ing] the number of times each Justice was a member of a winning coalition of any size (i.e., five, six, seven, eight, or nine Justices, or a four-Justice plurality)." 90 "The Jus-

83. Id. at 192.

84. Sultans of Swing, supra note 3, at 230; cf. Baker, supra note 2, at 201 (asserting that a "Justice who stands at the 'margin' of two groups of her colleagues necessarily stands at the Court's center" and therefore fulfills "the very definition of the 'median' Justice in whom Edelman and Chen ultimately claim to have no interest").

85. S. Sidney Ulmer, Toward a Theory of Sub-Group Formation in the United States Supreme Court, 27 J. POL. 133, 141 (1965).

86. Sultans of Swing, supra note 3, at 232.

87. Id. at 230; cf. Jeffrey A. Segal \& Albert D. Cover, Ideological Values and the Votes of U.S. Supreme Court Justices, 83 AM. POL. SCI. REV. 557, 557-65 (1989) (attempting to correlate journalistic assessments of the Justices' ideology with the Justices' actual votes in civil liberties cases from the 1953 Term to the 1988 Term).

88. Baker, supra note 2, at 192.

89. See Sultans of Swing, supra note 3, at 233.

90. Baker, supra note 2, at 202. 
tice with the highest total is the median Justice for that Term" and, by Professor Baker's measure of voting power, the Most Dangerous Justice. ${ }^{91}$ We shall borrow Professor Baker's nomenclature and refer to this yardstick as "Baker's standard measure." 92

\section{Baker's Decision Method}

In her critique of our original 1996 article, Professor Baker accused us of "believ[ing] that the benefits of considering only the decisions in which the winning coalition numbers precisely five Justices outweigh the costs of ignoring as much as eighty percent of the available data." ${ }^{.93}$ As an accommodation of this purported belief, Professor Baker proposed a simple measure based on "the number of times each Justice was a member of a five-Justice majority," under which the Justice "with the highest total during the relevant Term" would be crowned "the median or most powerful Justice." entirely accurate [" name that Professor Baker suggested-"the '5-4 Decision Method"'95 - we will call this measure "Baker's decision method." Baker's decision method is identical with our naive index except insofar as it counts multiple instances of each five-Justice coalition. Our naive index, of course, relies strictly on the number of unique five-Justice coalitions.

\section{Modified Median Measure}

In response to Baker's standard measure, we proposed two adjustments. First, disclaiming interest "in coalitions that lack the strength to control legal reasoning," we nullified "Professor Baker's decision to count submajority decisions" and "ignore[d] all coalitions smaller than five." Af After all, "starting with a minimal winning coalition is in the spirit of other cooperative game theory analyses" of Supreme Court decisionmaking. ${ }^{97}$ This modification apparently has minimal impact; the inclusion

91. Id.

92. Cf. id. (describing this method as "the Standard Measure").

93. Id.; see also id. at 193 ("Edelman and Chen ... consider only five-Justice coalitions"). For our response to this contention, see Sultans of Swing, supra note 3 , at 221-24.

94. Baker, supra note 2, at 202.

95. Id.

96. Sultans of Swing, supra note 3, at 233 .

97. Edelman \& Sherry, supra note 35 , at 1236. 
of submajority coalitions did not materially affect Professor Baker's assessment of voting power during the 1994 and 1995 Terms. No Justice appeared in more than two submajority coalitions credited by Professor Baker. Because the closest gap between Justices in Professor Baker's standard measure of voting power was three decisions, ${ }^{98}$ ignoring all submajority coalitions would not affect the Justices' rankings.

A second modification has far greater potential to affect Professor Baker's search for the median Justice. To minimize the impact of "docket bias" on the measurement of voting power during any single Supreme Court Term, we chose not to "count] multiple instances of each coalition," as Professor Baker did, but rather to count only "the number of different winning coalitions." ${ }^{.99}$ There is no statistically significant correlation between frequency of authorship and power measured through the Shapley-Shubik index, ${ }^{100}$ which after all is the measurement of power that Professor Baker favors. By "count[ing] the number of different winning coalitions-defined as coalitions of five or more-that each Justice joined" in any Term or stretch of Terms, we can easily derive a sense of the Court's median Justice. ${ }^{101}$ In 1996 we computed "median Justice power ratings" based on these modifications, ${ }^{102}$ and we will do so again in this study. To distinguish this method from Professor Baker's original proposal, we will call it the "modified median measure."

\section{LET THE GAMES BEGIN}

We now have three measures derived in varying degrees from Banzhafs definition of voting power-the naive, sophisticated, and generalized Banzhaf indexes-and three measures intended to determine the median Justice. Part III of this Article will apply all six measures to the decisions of the Supreme

98. See Baker, supra note 2, at 206 tbl.5.

99. Sultans of Swing, supra note 3, at 233-34.

100. See Charles A. Johnson, The Shapley-Shubik Power Index and the Supreme Court: A Few Empirical Notes, 18 JURIMETRICS J. 40, 43-44 (1977); see also id. at $43 \mathrm{n} .11$ (emphasizing that this methodology measures the number of opinions written relative to the total number of cases in which a Justice appears in the majority, so as to control for misleading effects attributable solely to a Justice's availability to be assigned an opinion); S. Sidney Ulmer, The Use of Power in the Supreme Court: The Opinion Assignments of Earl Warren, 19531960, 19 J. PUB. L. 49, 54 (1970) (same).

101. Sultans of Swing, supra note 3, at 234.

102. Id. at 235-36. 
Court from the 1994 Term through the 2000 Term. We have at hand the complete theoretical apparatus and empirical information needed to restage the Power Pageant of the Justices. At stake is the title of Most Dangerous Justice of the ClintonRehnquist Court.

Since the beginning of our project, we have acknowledged that the need for the "elaborate mathematics" so dreaded by our chief critic might wither away over time. ${ }^{103}$ The slow accretion of decisions may eliminate the need for indirect measures of feasibility. We developed a technique for inferring feasibility from observed coalitions because a "single Term's docket" is but "a limited cross-selection of the vastly more diverse workload that confronts the Court over a period of years." 104 "Over the long haul," however, "the extraordinary diversity of the Court's business erodes the docket's effect on the Justices' voting power." ${ }^{105}$ For any Justice interested in maximizing leverage on the bench, the long run puts a premium on ideological flexibility. Each "Justice's relative power ... will depend heavily on his ability to bend at the frontiers of his jurisprudential preferences."106 For a mathematically inclined observer of the Court, the long run does not complicate, but rather simplifies. Of their own force, the "larger number of cases decided by a single Court [may] obviate the need to rely on a mathematical surrogate for the Justices' coalition-building propensities." 107

Now that the Court has operated seven Terms with the same personnel-Chief Justice Rehnquist and Associate Justices Stevens, O'Connor, Scalia, Kennedy, Souter, Thomas, Ginsburg, and Breyer-we no longer need to "wait, perhaps bootlessly, for one group of Supreme Court Justices to accumulate a workable record of decisions." 108 The Clinton-Rehnquist Court has decided a sufficiently deep and diverse set of cases to expose precisely which coalitions among the Justices are feasible. As observers we can now refine or perhaps even discard "imperfect but mathematically cogent measure[s] of the Court's

103. Baker, supra note 2, at 190; cf. Baker v. Carr, 369 U.S. 186, 268 (1962) (Frankfurter, J., dissenting) (warning against "the mathematical quagmire" into which federal judicial supervision of state legislative elections would "catapult] the lower courts of the country").

104. Sultans of Swing, supra note 3, at 233.

105. Dangerous Justice, supra note 1 , at 97.

106. Id.

107. Sultans of Swing, supra note 3, at 225.

108. Id. at 226. 
voting power," which we developed in the absence of more complete information. ${ }^{109}$ We will therefore conduct another Power Pageant of the Justices, subjecting our three measures of voting power-the naive, sophisticated, and generalized Banzhaf indexes-as well as the standard, decision, and modified measures of the "median" Justice to an empirical test based on all Supreme Court decisions rendered in October Terms 1994 through 2000.

Without further ado, let the games begin.

III. THE MOST DANGEROUS JUSTICE RIDES AGAIN

\section{A. VARIATIONS ON A THEME BY BANZHAF}

1. Naive Index

We begin with our naive index of Supreme Court power. Applied Term by Term, this admittedly crude index foreshadows the decisive struggles in the Power Pageant of the Justices. In the next table and the eleven that follow it, the first line in each cell reports the amount of voting power-expressed as a percentage of the Court's overall power-that the Justice in question wielded during a particular Term. The second line reports a judicial quotient, or JQ, which is merely the corresponding power index multiplied by nine. A benchmark power index of $11.1 \%$, which is what an average Justice should expect, corresponds with a JQ of 100 . Herewith the Term-by-Term results of our naive index:

109. Id. 
Table 2: Naive Index, Term by Term

\begin{tabular}{||c|c|c|c|c|c|c|c|c|c||}
\hline \hline Term & CJ & JPS & SOC & AS & AMK & DHS & CT & RBG & SGB \\
\hline \multirow{2}{*}{1994} & 13.8 & 10.8 & 10.8 & 6.2 & 15.4 & 12.3 & 4.6 & 15.4 & 10.8 \\
& 125 & 97 & 97 & 55 & 138 & 111 & 42 & 138 & 97 \\
\hline \multirow{2}{*}{1995} & 7.5 & 10.0 & 15.0 & 10.0 & 12.5 & 15.0 & 7.5 & 12.5 & 10.0 \\
& 68 & 90 & 135 & 90 & 113 & 135 & 68 & 113 & 90 \\
\hline \multirow{2}{*}{1996} & 10.0 & 16.0 & 8.0 & 6.0 & 16.0 & 14.0 & 8.0 & 10.0 & 12.0 \\
& 90 & 144 & 72 & 54 & 144 & 126 & 72 & 90 & 108 \\
\hline 1997 & 10.9 & 14.5 & 10.9 & 5.5 & 12.7 & 10.9 & 9.1 & 10.9 & 14.5 \\
& 98 & 131 & 98 & 49 & 115 & 98 & 82 & 98 & 131 \\
\hline 1998 & 9.1 & 12.7 & 10.9 & 10.9 & 12.7 & 10.9 & 10.9 & 12.7 & 9.1 \\
& 82 & 115 & 98 & 98 & 115 & 98 & 98 & 115 & 82 \\
\hline 1999 & 10.9 & 9.1 & 12.7 & 7.3 & 10.9 & 14.5 & 12.7 & 9.1 & 12.7 \\
& 98 & 82 & 115 & 65 & 98 & 131 & 115 & 82 & 115 \\
\hline 2000 & 10.0 & 10.0 & 7.5 & 12.5 & 15.0 & 12.5 & 10.0 & 12.5 & 10.0 \\
& 90 & 90 & 68 & 112 & 135 & 112 & 90 & 90 & 90 \\
\hline
\end{tabular}

Justice Kennedy dominates these ratings. In every Term except 1999, he finished no lower than a tie for third. Justice Souter is almost as consistent and almost as powerful, approaching or surpassing the benchmark JQ of 100 in every Term. Every Justice has enjoyed at least one banner year in which his or her naive power index exceeded 11.1.

Computing the naive power index over time provides a surprisingly vivid measure of the Justices' relative strengths: 
Table 3: Naive Index, Cumulative

\begin{tabular}{||c|c|c|c|c|c|c|c|c|c||}
\hline Term & CJ & JPS & SOC & AS & AMK & DHS & CT & RBG & SGB \\
\hline \multirow{2}{*}{1994} & 13.8 & 10.8 & 10.8 & 6.2 & 15.4 & 12.3 & 4.6 & 15.4 & 10.8 \\
& 125 & 97 & 97 & 55 & 138 & 111 & 42 & 138 & 97 \\
\hline $94-95$ & 12.9 & 9.4 & 12.9 & 7.1 & 14.1 & 12.9 & 5.9 & 14.1 & 10.6 \\
& 116 & 85 & 116 & 64 & 127 & 116 & 53 & 127 & 95 \\
\hline $94-96$ & 13.6 & 10.9 & 10.0 & 7.3 & 14.5 & 13.6 & 7.3 & 12.7 & 10.0 \\
& 123 & 98 & 90 & 65 & 131 & 123 & 65 & 115 & 90 \\
\hline $94-97$ & 12.5 & 11.9 & 10.4 & 6.7 & 14.1 & 12.6 & 8.1 & 11.9 & 11.9 \\
& 113 & 107 & 93 & 60 & 127 & 113 & 73 & 107 & 107 \\
\hline $94-98$ & 12.7 & 12.0 & 10.0 & 7.3 & 14.0 & 12.0 & 9.3 & 12.0 & 10.7 \\
& 114 & 108 & 90 & 66 & 126 & 108 & 84 & 108 & 96 \\
\hline $94-99$ & 12.6 & 11.4 & 10.3 & 7.4 & 14.3 & 12.6 & 9.7 & 10.9 & 10.9 \\
& 113 & 103 & 93 & 67 & 129 & 113 & 87 & 98 & 98 \\
\hline $94-2000$ & 11.9 & 11.4 & 9.7 & 8.1 & 14.1 & 12.4 & 9.7 & 11.4 & 11.4 \\
& 107 & 102 & 88 & 73 & 126 & 112 & 88 & 102 & 102 \\
\hline
\end{tabular}

The cumulative computation of the naive index shows stability over time. Significant variation in power ratings does exist, and those differences tend to persist. Justices Kennedy and Souter are able to translate consistently powerful annual performances into domination of the cumulative table. Despite considerably spottier yearly showings, Chief Justice Rehnquist has fared reasonably well. The Chief Justice, in fact, has matched or outperformed Justice Souter after five of seven Terms in the cumulative naive index, even though Justice Souter beat the Chief Justice in five of seven annual contests and tied him in a sixth. Justices Ginsburg, Stevens, and Breyer wield almost exactly the voting power that they should expect. Justices O'Connor, Thomas, and Scalia bring up the rear.

Justices Ginsburg and Thomas exhibit some of the most interesting changes in relative power over time. When we first examined this problem in 1996, we ranked Justice Ginsburg among the most powerful Justices. We awarded her the title of Most Dangerous Justice for October Term $1995 .{ }^{110}$ Nothing in

110. See Dangerous Justice, supra note 1, at 95. 
the naive index undermines that decision. During the 1994 and 1995 Terms, Justice Ginsburg wielded nearly three times the power of Justice Thomas and more than twice that of Justice Scalia. At her nadir after the 1999 Term, Justice Ginsburg had shed 4.5 points off her peak performance in the cumulative naive index. By the end of the 2000 Term, Justice Ginsburg eased into a three-way tie for fourth place, behind Justice Kennedy, Justice Souter, and Chief Justice Rehnquist.

For his part, Justice Thomas surged. In most other circumstances, a final naive power rating of 9.7 and a JQ of eighty-eight would not warrant much notice. But in reaching that level, Justice Thomas more than doubled the power that he had exerted at the outset. After beginning in the cellar, Justice Thomas reached parity with Justice Scalia after the 1996 Term and has never trailed since. He now enjoys a substantial edge over Justice Scalia.

\section{Sophisticated Index}

Introducing the notion of feasibility initially confounds our application of Professor Banzhafs measure of voting power. Thanks to the stringent requirement of proving feasibility through actual observation of lesser-included coalitions of four Justices, the annual ratings are pockmarked with zeroes at one extreme and stratospherically high JQs at the other: 
Table 4: Sophisticated Index, Term by Term

\begin{tabular}{||c|c|c|c|c|c|c|c|c|c||}
\hline \hline Term & CJ & JPS & SOC & AS & AMK & DHS & CT & RBG & SGB \\
\hline 1994 & 13.3 & 0.0 & 20.0 & 13.3 & 6.7 & 13.3 & 0.0 & 13.3 & 13.3 \\
& 120 & 0 & 180 & 120 & 60 & 120 & 0 & 120 & 120 \\
\hline 1995 & 0.0 & 0.0 & 20.0 & 10.0 & 30.0 & 10.0 & 0.0 & 20.0 & 10.0 \\
& 0 & 0 & 180 & 90 & 270 & 90 & 0 & 180 & 90 \\
\hline 1996 & 20.0 & 0.0 & 20.0 & 0.0 & 30.0 & 10.0 & 10.0 & 0.0 & 10.0 \\
& 180 & 0 & 180 & 0 & 270 & 90 & 90 & 0 & 90 \\
\hline \multirow{2}{*}{1997} & 6.3 & 6.3 & 12.5 & 18.8 & 12.5 & 6.3 & 12.5 & 12.5 & 12.5 \\
& 56 & 56 & 113 & 169 & 113 & 56 & 113 & 113 & 113 \\
\hline 1998 & 0.0 & 11.1 & 22.2 & 16.7 & 16.7 & 16.7 & 5.6 & 5.6 & 5.6 \\
& 0 & 100 & 200 & 150 & 150 & 150 & 50 & 50 & 50 \\
\hline 1999 & 5.9 & 5.9 & 17.6 & 17.6 & 11.8 & 17.6 & 11.8 & 0.0 & 11.8 \\
& 53 & 53 & 159 & 159 & 106 & 159 & 106 & 0 & 106 \\
\hline 2000 & 0.0 & 22.2 & 22.2 & 11.1 & 22.2 & 22.2 & 0.0 & 0.0 & 0.0 \\
& 0 & 200 & 200 & 100 & 200 & 200 & 0 & 0 & 0 \\
\hline
\end{tabular}

The 2000 Term, to pick but the most recent example, illustrates the implausibility of the sophisticated index as an annual measure of Supreme Court voting power. It defies credibility to assert, as this index does, that Justices Stevens, O'Connor, Scalia, Kennedy, and Souter alone commanded all of the Court's power, to the complete exclusion of their four colleagues. Once feasibility is permitted to work over time, however, the performance of the sophisticated index improves dramatically: 
Table 5: Sophisticated Index, Cumulative

\begin{tabular}{||c|c|c|c|c|c|c|c|c|c||}
\hline \hline Term & CJ & JPS & SOC & AS & AMK & DHS & CT & RBG & SGB \\
\hline 1994 & 13.3 & 0.0 & 20.0 & 20.0 & 13.3 & 6.7 & 0.0 & 13.3 & 13.3 \\
& 120 & 0 & 180 & 180 & 120 & 60 & 0 & 120 & 120 \\
\hline $94-95$ & 14.3 & 0.0 & 19.0 & 14.3 & 14.3 & 9.5 & 0.0 & 19.0 & 9.5 \\
& 129 & 0 & 171 & 129 & 129 & 86 & 0 & 171 & 86 \\
\hline $94-96$ & 19.4 & 0.0 & 16.7 & 8.3 & 13.9 & 13.9 & 2.8 & 13.9 & 11.1 \\
& 175 & 0 & 150 & 75 & 125 & 125 & 25 & 125 & 100 \\
\hline $94-97$ & 15.4 & 7.7 & 11.5 & 9.6 & 15.4 & 13.5 & 5.8 & 9.6 & 11.5 \\
& 138 & 69 & 104 & 87 & 138 & 121 & 52 & 87 & 104 \\
\hline $94-98$ & 12.9 & 9.7 & 11.3 & 9.7 & 14.5 & 12.9 & 8.1 & 11.3 & 9.7 \\
& 116 & 87 & 102 & 87 & 131 & 116 & 73 & 102 & 87 \\
\hline $94-99$ & 11.4 & 7.6 & 10.1 & 10.1 & 15.2 & 16.5 & 10.1 & 8.9 & 10.1 \\
& 103 & 76 & 91 & 91 & 137 & 148 & 91 & 80 & 91 \\
\hline \multirow{2}{*}{$94-2000$} & 10.6 & 7.1 & 9.4 & 10.6 & 14.1 & 18.8 & 10.6 & 8.2 & 10.6 \\
& 95 & 64 & 85 & 95 & 127 & 169 & 95 & 74 & 95 \\
\hline
\end{tabular}

Justices Kennedy and Souter again dominate the rankings. Relative to the naive index, however, the sophisticated index seems prone to occasional seismic shifts. Justice Souter had never eclipsed Justice Kennedy until the 1999 Term. Indeed, he began with exactly half of Justice Kennedy's power. In the 1999 Term, however, Justice Souter gained 3.6 points on his power index and skyrocketed past Justice Kennedy and Chief Justice Rehnquist, two colleagues whom he had trailed in the cumulative naive index and in the Term-by-Term application of the sophisticated index. He continued his surge in the 2000 Term, finishing with an astonishing 18.8 index and a forty-twopoint lead in JQ over his closest competitor, Justice Kennedy. In all, Justice Souter gained nearly six percentage points in his power rating in two Terms.

At the close of the 2000 Term, Justice Kennedy nevertheless retained an impressive amount of power. With a JQ of 127 , he exceeds his expected power by more than a quarter. At a lower level of power, Justice Thomas has registered impressive gains in recent Terms. Since the end of the 1997 Term, Justice Thomas has added nearly five points to his index and practically doubled his JQ. Over the same period, Chief Justice 
Rehnquist lost as much strength as Justice Thomas gained, shedding 4.8 index points and forty-three points of JQ. From his peak at the end of October Term 1996, the Chief Justice has lost nearly half of his power. As in the cumulative naive index, Justice Ginsburg has also fallen sharply over time. Since the end of the 1995 Term, she has dropped a whopping 10.8 index points and ninety-seven points in JQ. She lost more power than six other Justices on the Court hold. These dramatic shifts have vaulted Justice Thomas and relegated Chief Justice Rehnquist into a four-way tie for third. For her part, Justice Ginsburg now languishes in eighth place.

The sophisticated index is particularly cruel to Justice Stevens, who alone occupies last place with half of the power wielded by the runner-up, Justice Kennedy. Indeed, for the first three Terms of our study period, the cumulative sophisticated index awarded Justice Stevens none of the Court's voting power. After seven Terms, he holds a scant $7.1 \%$ of the Court's power and lags in last place by a substantial margin.

Justice O'Connor's performance in the sophisticated index warrants special mention. On a Term-by-Term basis, she has achieved remarkably high ratings. Indeed, only in the 1997 Term did she fail to approach or reach the eye-popping JQ of 200. In our cumulative application of the sophisticated index, however, Justice O'Connor steadily ebbed from an initial index of 20.0 and JQ of 180 to less than half those levels of power. Her final rating under the sophisticated index-an index of 9.4 and a JQ of eighty-five-is consistent with her assessment under the naive index.

From this story we draw two conclusions. First, as a matter of method, Justice O'Connor's performance demonstrates that the cumulative application of our naive and sophisticated indexes does not follow in linear fashion from the yearly version of those indexes. The cumulative analysis differs dramatically from the average of the yearly indexes. Even after her record-setting performance in the 2000 Term, she actually lost more than a tenth of her power. Second, we have confirmed a conclusion that we reached in 1996: "Sandra Day O'Connor [is] one of the Supreme Court's weaker Justices." 11 Breathless portrayals of Justice O'Connor as the Court's most influential member $^{112}$ draw no support from our quantitative analysis of

111. Id. at 98 .

112. See, e.g., Jeffrey Rosen, A Majority of One, N.Y. TIMES MAG., June 3, 2001 , at 32 . 
her performance. After seven Terms, Justice O'Connor has registered JQs in the 80s under both the naive and the sophisticated indexes. Judicial greatness should be made of sterner stuff.

3. Generalized Banzhaf Index

Our technique of inferring feasibility from the coalitions observed in any given single Term, which is by far the most elaborate of our indexes, performed erratically:

Table 6: Generalized Banzhaf Index, Term by Term

\begin{tabular}{||l|c|c|c|c|c|c|c|c|c||}
\hline Term & CJ & JPS & SOC & AS & AMK & DHS & CT & RBG & SGB \\
\hline 1994 & 9.6 & 10.9 & 8.6 & 12.1 & 13.4 & 11.2 & 8.6 & 13.1 & 12.5 \\
& 86 & 98 & 77 & 109 & 121 & 101 & 77 & 118 & 112 \\
\hline 1995 & 12.0 & 6.8 & 12.0 & 11.5 & 12.6 & 11.5 & 11.0 & 13.6 & 8.9 \\
& 108 & 61 & 108 & 104 & 113 & 104 & 99 & 123 & 80 \\
\hline 1996 & 9.8 & 8.0 & 12.6 & 9.2 & 8.6 & 14.4 & 10.3 & 14.9 & 12.1 \\
& 88 & 71 & 114 & 83 & 78 & 129 & 93 & 134 & 109 \\
\hline 1997 & 9.9 & 12.6 & 13.1 & 5.8 & 10.5 & 14.7 & 8.4 & 11.0 & 14.1 \\
& 90 & 113 & 118 & 52 & 94 & 132 & 75 & 99 & 127 \\
\hline 1998 & 11.9 & 10.5 & 11.5 & 11.5 & 11.2 & 12.2 & 8.0 & 11.2 & 11.9 \\
& 107 & 94 & 104 & 104 & 101 & 110 & 72 & 101 & 107 \\
\hline 1999 & 11.6 & 6.1 & 6.7 & 11.6 & 11.6 & 11.0 & 14.0 & 12.8 & 14.6 \\
& 104 & 55 & 60 & 104 & 104 & 99 & 129 & 115 & 132 \\
\hline \multirow{2}{*}{2000} & 8.9 & 9.4 & 11.5 & 10.5 & 8.9 & 13.1 & 11.0 & 14.1 & 12.6 \\
& 80 & 85 & 104 & 94 & 80 & 118 & 99 & 127 & 113 \\
\hline \hline
\end{tabular}

The perennial winners under this measure are Justices Ginsburg, Breyer, and Souter. All three have avoided a Term of significant underperformance (defined as falling short of expected voting power by more than twenty percent), and all three have enjoyed at least two Terms marked by JQs over 120 . Justice Kennedy fares noticeably worse, relative to his showing in our simpler indexes. Finally, Justices Stevens and O'Connor demonstrate radical shifts in power not evident from, much less consonant with, power shifts suggested by the naive index. In the generalized Banzhaf index, which is designed to predict long-term coalition building ability from short-term data, swings exceeding six percentage points separate the highest from the lowest annual ratings for Justices Stevens and 


\section{O'Connor.}

The generalized Banzhaf index completely collapses when computed over time:

Table 7: Generalized Banzhaf Index, Cumulative

\begin{tabular}{||c|c|c|c|c|c|c|c|c|c||}
\hline Term & CJ & JPS & SOC & AS & AMK & DHS & CT & RBG & SGB \\
\hline 1994 & 9.6 & 10.9 & 8.6 & 12.1 & 13.4 & 11.2 & 8.6 & 13.1 & 12.5 \\
& 86 & 98 & 77 & 109 & 121 & 101 & 77 & 118 & 112 \\
\hline $94-95$ & 11.5 & 9.9 & 9.9 & 10.6 & 12.4 & 12.1 & 10.2 & 12.6 & 10.8 \\
& 103 & 89 & 89 & 95 & 111 & 109 & 91 & 113 & 97 \\
\hline $94-96$ & 11.1 & 9.3 & 10.3 & 11.5 & 11.9 & 12.1 & 11.1 & 12.1 & 10.9 \\
& 100 & 84 & 93 & 103 & 107 & 108 & 100 & 108 & 98 \\
\hline $94-97$ & 11.2 & 10.2 & 10.2 & 11.1 & 11.8 & 11.8 & 11.1 & 11.4 & 11.4 \\
& 101 & 91 & 91 & 99 & 106 & 106 & 99 & 103 & 103 \\
\hline $94-98$ & 11.2 & 10.9 & 10.9 & 11.2 & 11.2 & 11.1 & 11.1 & 11.2 & 11.2 \\
& 101 & 98 & 98 & 101 & 101 & 100 & 100 & 101 & 101 \\
\hline \multirow{2}{*}{$94-99$} & 11.2 & 11.0 & 11.0 & 11.0 & 11.0 & 11.2 & 11.2 & 11.2 & 11.0 \\
& 101 & 99 & 99 & 99 & 99 & 101 & 101 & 101 & 99 \\
\hline $94-2000$ & 11.2 & 11.0 & 11.0 & 11.0 & 11.0 & 11.2 & 11.2 & 11.2 & 11.0 \\
& 101 & 99 & 99 & 99 & 99 & 101 & 101 & 101 & 99 \\
\hline
\end{tabular}

Over time, our method for inferring feasibility generates so many of the mathematically possible combinations that it no longer provides useful information. By the end of October Term 2000, 497 of 512 combinations were deemed feasible. Only fourteen combinations, plus the legally impossible null set, remained out of reach. We therefore abandon the cumulative form of the generalized Banzhaf index as a long-run gauge of voting power on the Supreme Court.

\section{B. MUSings ON THE MEANING OF THE MEDIAN}

We now turn to Professor Lynn Baker's alternatives to our indexes. Professor Baker's measures of voting power on the Supreme Court differ from ours in that she believes that a median Justice for each controversy exists and can be discovered. Her search therefore focuses on the supposed ideological pivot of the Court. We will now present three alternative methods of identifying the median Justice. First, we will present Professor 
Baker's "standard measure," which counts the total number of decisions in which each Justice votes with the prevailing side. Second, we will test Professor Baker's own alternative to her standard measure: the "decision method" of counting the total number of cases decided by each five-Justice coalition. Finally, we will apply a modified median measure, which shares our technique of counting only the number of unique coalitions, without regard to frequency of repetition.

\section{Baker's Standard Measure}

Professor Baker's standard measure bears some resemblance to our naive index. Like our simplest measure, Professor Baker relies on plain addition: the greater the number of relevant decisions in which a Justice's views prevail, the greater that Justice's imputed voting power. Like our naive index, Baker's standard measure also exhibits stability Term to Term:

Table 8: Baker's Standard Measure, Term by Term

\begin{tabular}{||c|c|c|c|c|c|c|c|c|c||}
\hline Term & CJ & JPS & SOC & AS & AMK & DHS & CT & RBG & SGB \\
\hline \multirow{2}{*}{1994} & 11.8 & 9.7 & 11.5 & 10.2 & 12.5 & 11.5 & 9.7 & 11.7 & 11.4 \\
& 106 & 87 & 104 & 92 & 113 & 104 & 87 & 105 & 102 \\
\hline \multirow{2}{*}{1995} & 11.1 & 9.4 & 11.8 & 10.7 & 12.3 & 12.0 & 10.3 & 11.5 & 10.8 \\
& 100 & 85 & 106 & 96 & 110 & 108 & 93 & 104 & 98 \\
\hline 1996 & 11.8 & 9.9 & 11.5 & 10.4 & 12.8 & 11.3 & 10.9 & 10.9 & 10.5 \\
& 106 & 89 & 104 & 94 & 115 & 102 & 98 & 98 & 95 \\
\hline 1997 & 12.2 & 10.2 & 11.8 & 9.6 & 12.6 & 11.2 & 10.4 & 10.6 & 11.4 \\
& 110 & 92 & 106 & 86 & 113 & 101 & 94 & 95 & 103 \\
\hline 1998 & 11.3 & 9.7 & 12.1 & 11.8 & 12.0 & 11.0 & 10.7 & 10.8 & 10.6 \\
& 101 & 87 & 109 & 106 & 108 & 99 & 96 & 98 & 95 \\
\hline \multirow{2}{*}{1999} & 12.8 & 8.7 & 13.8 & 10.4 & 12.4 & 10.6 & 11.7 & 10.0 & 10.0 \\
& 115 & 79 & 121 & 93 & 111 & 95 & 105 & 90 & 90 \\
\hline 2000 & 11.8 & 9.5 & 12.6 & 11.1 & 13.0 & 11.1 & 10.9 & 10.3 & 9.7 \\
& 106 & 85 & 113 & 100 & 117 & 100 & 98 & 93 & 88 \\
\hline
\end{tabular}

Though Professor Baker's margins are narrower than ours, her standard measure does suggest that some Justices wield more power than others. Justices Kennedy and O'Connor and the Chief Justice consistently exceed their expected power. 
Justice Souter hovers near par. All others lag, most notably Justice Stevens.

The steadfast readings generated by Baker's standard measure become even more strikingly stable when calculated cumulatively:

Table 9: Baker's Standard Measure, Cumulative

\begin{tabular}{||c|c|c|c|c|c|c|c|c|c||}
\hline Term & CJ & JPS & SOC & AS & AMIK & DHS & CT & RBG & SGB \\
\hline 1994 & 11.8 & 9.7 & 11.5 & 10.2 & 12.5 & 11.5 & 9.7 & 11.7 & 11.4 \\
& 106 & 87 & 104 & 92 & 113 & 104 & 87 & 105 & 102 \\
\hline $94-95$ & 11.5 & 9.6 & 11.7 & 10.5 & 12.4 & 11.7 & 10.0 & 11.6 & 11.1 \\
& 103 & 86 & 105 & 94 & 111 & 106 & 90 & 104 & 100 \\
\hline $94-96$ & 11.6 & 9.7 & 11.6 & 10.4 & 12.5 & 11.6 & 10.3 & 11.3 & 10.9 \\
& 104 & 87 & 105 & 94 & 113 & 104 & 93 & 102 & 98 \\
\hline $94-97$ & 11.7 & 9.8 & 11.7 & 10.2 & 12.5 & 11.5 & 10.3 & 11.1 & 11.0 \\
& 106 & 88 & 105 & 92 & 113 & 103 & 93 & 100 & 99 \\
\hline $94-98$ & 11.7 & 9.8 & 11.8 & 10.5 & 12.4 & 11.4 & 10.4 & 11.1 & 11.0 \\
& 105 & 88 & 106 & 95 & 112 & 102 & 94 & 100 & 99 \\
\hline $94-99$ & 11.8 & 9.7 & 12.0 & 10.5 & 12.4 & 11.3 & 10.6 & 10.9 & 10.8 \\
& 106 & 87 & 108 & 95 & 112 & 102 & 95 & 99 & 97 \\
\hline 94 & 11.8 & 9.6 & 12.1 & 10.6 & 12.5 & 11.3 & 10.6 & 10.9 & 10.7 \\
2000 & 106 & 87 & 109 & 95 & 113 & 101 & 96 & 98 & 96 \\
\hline
\end{tabular}

Baker's standard measure is the most stable of the gauges we apply. This is not an unequivocally positive trait; the large number of unanimous decisions rendered by the Court dominates her data. Since all Justices receive credit for participating in a unanimous decision, any variations among Justices in Professor Baker's standard measure depend on distinctions within non-unanimous decisions. This characteristic also explains why her standard measure produces noticeably narrower gaps between Justices.

Throughout a study period of seven Terms, every JQ falls within thirteen points of 100 . It seems implausible that every Justice on a Court filled with notoriously idiosyncratic personalities would vary from his or her expected voting power by no more than an eighth. To be sure, Professor Baker's standard measure does not exhibit the extreme convergence that plagues the cumulative application of our generalized Banzhaf index. Professor Baker's gauge suggests that the most powerful mem- 
bers of today's Court (albeit by comparatively narrow margins) are Justice Kennedy, Justice O'Connor, and Chief Justice Rehnquist. On the other hand, her standard measure may not reflect anything besides the propensity of a bloc dominated by these three Justices to decide a relatively large number of cases, often at the expense of the last-place finisher, Justice Stevens. It reveals little if anything about the ability of individual Justices to form coalitions with a wide range of partners.

For a look at the median Justice that even more closely resembles our naive index, we now turn to Professor Baker's decision method.

\section{Baker's Decision Method}

Professor Baker's own alternative method for discerning the "median" Justice is a docket-sensitive variation on our naive index. Like our naive index, this method relies solely on five-Justice coalitions. Unlike us, however, Professor Baker counts multiple instances of each coalition:

Table 10: Baker's Decision Method, Term by Term

\begin{tabular}{||c|c|c|c|c|c|c|c|c|c||}
\hline Term & CJ & JPS & SOC & AS & AMK & DHS & CT & RBG & SGB \\
\hline \multirow{2}{*}{1994} & 13.0 & 10.4 & 12.1 & 7.8 & 15.7 & 10.4 & 7.0 & 13.0 & 10.4 \\
& 117 & 94 & 110 & 70 & 141 & 94 & 63 & 117 & 94 \\
\hline 1995 & 9.2 & 9.2 & 15.4 & 10.8 & 13.8 & 12.3 & 9.2 & 10.8 & 9.2 \\
& 83 & 83 & 138 & 97 & 125 & 111 & 83 & 97 & 83 \\
\hline \multirow{2}{*}{1996} & 13.6 & 9.1 & 14.5 & 11.8 & 16.4 & 8.2 & 12.7 & 6.4 & 7.3 \\
& 123 & 82 & 131 & 106 & 147 & 74 & 115 & 57 & 65 \\
\hline \multirow{2}{*}{1997} & 13.3 & 9.5 & 13.3 & 9.5 & 16.2 & 7.6 & 12.4 & 7.6 & 10.5 \\
& 120 & 86 & 120 & 86 & 146 & 69 & 111 & 69 & 94 \\
\hline \multirow{2}{*}{1998} & 11.1 & 9.6 & 14.1 & 12.6 & 14.8 & 8.9 & 11.9 & 9.6 & 7.4 \\
& 100 & 87 & 127 & 113 & 133 & 80 & 107 & 87 & 67 \\
\hline \multirow{2}{*}{1999} & 15.8 & 4.2 & 16.7 & 14.2 & 15.8 & 6.7 & 16.7 & 4.2 & 5.8 \\
& 142 & 38 & 150 & 128 & 142 & 60 & 150 & 38 & 52 \\
\hline \multirow{2}{*}{2000} & 12.9 & 7.1 & 15.5 & 13.5 & 15.5 & 7.7 & 12.9 & 7.7 & 7.1 \\
& 116 & 64 & 139 & 122 & 139 & 70 & 116 & 70 & 64 \\
\hline \hline
\end{tabular}

Modifying our naive index to account for the frequency of certain coalitions shifts a noticeable amount of power toward the five members of the putatively conservative coalition of 
Chief Justice Rehnquist and Justices O'Connor, Scalia, Kennedy, and Thomas. This consolidation of power on the right evidently occurred through accretion rather than revolution. Indeed, the first two Terms of the Clinton-Rehnquist Court seemed ideologically contestable. Justice Ginsburg tied the Chief Justice for second place during the 1994 Term, and Justice Souter registered a strong third-place finish in the 1995 Term.

October Term 1996, however, changed everything. That Term witnessed the first above-par performances for Justices Scalia and Thomas, who had previously failed to vote their expected weight. Since the 1996 Term, the members of the conservative bloc have failed to reach par only once; Justice Scalia registered a disappointing 9.5 rating during the 1997 Term. The contrast is stark. Since 1996 the members of the conservative crew have exceeded the $100 \mathrm{JQ}$ benchmark twenty-three times out of twenty-five, met that figure once, and failed once. That translates to a success rate of ninety-two to ninety-six percent. During the 1994 and 1995 Terms, the same Justices reached the $100 \mathrm{JQ}$ benchmark in merely five of ten opportunities.

The 1996 Term also marked the beginning of the liberal wing's decline. In the 1994 Term, Justice Ginsburg tied the Chief Justice with a 13.0 rating, good for second place behind Justice Kennedy's 15.7 rating. Justice Souter finished a strong third the next Term with 12.3 index points. In the 1996 Term, however, both Justices Souter and Ginsburg plunged far beneath the benchmark JQ of 100 . They would never regain their earlier levels of performance. Indeed, from the 1996 Term onward, no member of the Court's liberal wing has ever reached par according to Professor Baker's decision method. In the 1999 Term, even as Justices O'Connor and Thomas tied for first, Justices Stevens, Souter, Ginsburg, and Breyer turned in appalling numbers. Their power ratings, respectively, were $4.2,6.7,4.2$, and 5.8. In other words, these four Justices put together captured scarcely more than a fifth of the entire Court's voting power. Either Justice O'Connor or Justice Thomas alone, with a rating of 16.7 , came dangerously close to matching the entire liberal wing.

Computing Professor Baker's decision method on a cumulative basis completes the analogy with our naive index: 
Table 11: Baker's Decision Method, Cumulative

\begin{tabular}{||c|c|c|c|c|c|c|c|c|c||}
\hline Term & CJ & JPS & SOC & AS & AMK & DHS & CT & RBG & SGB \\
\hline 1994 & 13.0 & 10.4 & 12.1 & 7.8 & 15.7 & 10.4 & 7.0 & 13.0 & 10.4 \\
& 117 & 94 & 110 & 70 & 141 & 94 & 63 & 117 & 94 \\
\hline $94-95$ & 11.7 & 10.0 & 13.3 & 8.9 & 15.0 & 11.1 & 7.8 & 12.2 & 10.0 \\
& 105 & 90 & 120 & 80 & 135 & 100 & 70 & 110 & 90 \\
\hline $94-96$ & 12.4 & 9.7 & 13.8 & 10.0 & 15.5 & 10.0 & 9.7 & 10.0 & 9.0 \\
& 112 & 87 & 124 & 90 & 140 & 90 & 87 & 90 & 81 \\
\hline $94-97$ & 12.7 & 9.6 & 13.7 & 9.9 & 15.7 & 9.4 & 10.4 & 9.4 & 9.4 \\
& 114 & 87 & 123 & 89 & 141 & 84 & 93 & 84 & 84 \\
\hline $94-98$ & 12.3 & 9.6 & 13.8 & 10.6 & 15.5 & 9.2 & 10.8 & 9.4 & 8.9 \\
& 110 & 87 & 124 & 95 & 139 & 83 & 97 & 85 & 80 \\
\hline $94-99$ & 12.9 & 8.6 & 14.3 & 11.2 & 15.5 & 8.8 & 11.8 & 8.5 & 8.3 \\
& 116 & 78 & 129 & 101 & 140 & 79 & 107 & 76 & 75 \\
\hline $94-$ & 12.9 & 8.3 & 14.5 & 11.7 & 15.6 & 8.6 & 12.0 & 8.3 & 8.1 \\
2000 & 116 & 75 & 131 & 105 & 140 & 77 & 108 & 75 & 73 \\
\hline \hline
\end{tabular}

The impact of the Court's docket becomes strikingly evident in the cumulative application of Professor Baker's decision method. By the end of the 2000 Term, the members of the liberal coalition of Justices Stevens, Souter, Ginsburg, and Breyer were reduced to three-quarters of their expected voting power. All four are now mired between 8.1 and 8.6 index points, exercising on average a pallid three-quarters of their expected voting power. Justice Scalia, the weakest of the conservatives, outvotes each of the liberals by at least three full percentage points. Every member of the frequently encountered conservative coalition consisting of the Chief Justice and Justices O'Connor, Scalia, Kennedy, and Thomas now enjoys more than his or her expected share of the Court's power. Justices Kennedy and O'Connor dominate the ratings, while the Chief Justice presents a formidable third-place profile.

The changes in this index over time also bear notice. Collectively, Justices Stevens, Ginsburg, and Breyer exerted just slightly more than their expected voting power after October Term 1994. At that time, Justices O'Connor, Scalia, and Thomas commanded an average power index near 9.0, good for a $\mathrm{JQ}$ in the neighborhood of eighty. Six Terms later, Justice Ginsburg has yielded forty-two points of JQ, while Justice Thomas has added forty-five points. Supreme Court voting 
power really is a zero-sum game. The strength that Justices Breyer and Stevens have lost over this period has found its way into the power ratings of Justices Scalia and O'Connor.

No other gauge of Supreme Court behavior divides voting power along such overtly ideological lines. We believe that Professor Baker's decision method ultimately measures little beyond conservative dominance of the Court's docket since 1994 (or at least since 1996). In an era dominated by the shadow of Bush v. Gore, ${ }^{113}$ what started out as the Clinton-Rehnquist Court is now more appropriately considered the Rehnquist Court, simplicter.

\section{Modified Median Measure}

Focusing solely on the number of unique coalitions rather than the number of decisions decided by each coalition comes much closer to fulfilling the quest for the median Justice. Unlike either of Professor Baker's measures, what we call the modified median measure assesses each Justice's propensity to join a winning coalition while minimizing influence from the Court's docket:

113. 121 S. Ct. 525 (2000) (per curiam). 
Table 12: Modified Median Measure, Term by Term

\begin{tabular}{||c|c|c|c|c|c|c|c|c|c||}
\hline Term & CJ & JPS & SOC & AS & AMK & DHS & CT & RBG & SGB \\
\hline \multirow{2}{*}{1994} & 12.6 & 9.9 & 10.3 & 9.4 & 13.5 & 12.1 & 7.6 & 13.5 & 11.2 \\
& 113 & 89 & 93 & 85 & 121 & 109 & 69 & 121 & 101 \\
\hline \multirow{2}{*}{1995} & 10.5 & 8.9 & 12.6 & 10.0 & 13.2 & 13.2 & 8.9 & 12.1 & 10.5 \\
& 95 & 81 & 114 & 90 & 118 & 118 & 81 & 109 & 95 \\
\hline \multirow{2}{*}{1996} & 10.9 & 9.9 & 10.3 & 9.4 & 14.4 & 12.4 & 10.4 & 11.9 & 10.4 \\
& 98 & 89 & 94 & 85 & 129 & 111 & 94 & 107 & 94 \\
\hline 1997 & 12.4 & 10.9 & 11.9 & 7.4 & 13.4 & 12.4 & 9.4 & 9.9 & 12.4 \\
& 111 & 98 & 107 & 67 & 120 & 111 & 85 & 89 & 111 \\
\hline 1998 & 10.8 & 10.8 & 11.3 & 12.3 & 10.8 & 11.3 & 9.9 & 11.3 & 11.3 \\
& 98 & 98 & 102 & 110 & 98 & 102 & 89 & 102 & 102 \\
\hline 1999 & 11.7 & 8.3 & 13.3 & 8.9 & 11.1 & 12.8 & 11.1 & 11.1 & 11.7 \\
& 105 & 75 & 120 & 80 & 100 & 115 & 100 & 100 & 105 \\
\hline 2000 & 11.3 & 9.1 & 10.2 & 10.8 & 13.6 & 13.1 & 10.2 & 11.4 & 10.2 \\
& 102 & 82 & 92 & 97 & 123 & 118 & 92 & 102 & 92 \\
\hline
\end{tabular}

Modifying Professor Baker's standard measure to exclude the effects of the Court's docket shifts a noticeable amount of power toward Justice Souter in every Term. In most Terms, Justice Kennedy also registers respectable numbers, while Chief Justice Rehnquist, Justice Ginsburg, and Justice Breyer struggle to remain above par. Justice Thomas's ascension and Justice Ginsburg's corresponding decline are also evident, though less so than in our indexes: 
Table 13: Modified Median Measure, Cumulative

\begin{tabular}{||c|c|c|c|c|c|c|c|c|c||}
\hline Term & CJ & JPS & SOC & AS & AMK & DHS & CT & RBG & SGB \\
\hline 1994 & 12.6 & 9.9 & 10.3 & 9.4 & 13.5 & 12.1 & 7.6 & 13.5 & 11.2 \\
& 113 & 89 & 93 & 85 & 121 & 109 & 69 & 121 & 101 \\
\hline $94-95$ & 12.1 & 9.2 & 11.4 & 10.2 & 13.0 & 12.1 & 8.9 & 12.7 & 10.5 \\
& 109 & 83 & 103 & 91 & 117 & 109 & 80 & 114 & 94 \\
\hline $94-96$ & 11.8 & 9.4 & 10.5 & 10.2 & 13.4 & 12.3 & 9.7 & 12.6 & 10.2 \\
& 106 & 85 & 94 & 92 & 120 & 111 & 87 & 113 & 92 \\
\hline $94-97$ & 11.6 & 10.1 & 10.5 & 9.7 & 13.4 & 12.1 & 9.9 & 11.6 & 11.0 \\
& 105 & 91 & 95 & 87 & 120 & 109 & 89 & 105 & 99 \\
\hline $94-98$ & 11.7 & 10.6 & 10.4 & 10.2 & 12.5 & 11.7 & 10.2 & 11.7 & 11.0 \\
& 106 & 95 & 93 & 92 & 113 & 106 & 92 & 106 & 99 \\
\hline $94-99$ & 11.8 & 10.5 & 10.5 & 9.9 & 12.5 & 12.0 & 10.3 & 11.4 & 11.0 \\
& 106 & 94 & 94 & 90 & 113 & 108 & 93 & 103 & 99 \\
\hline $94-$ & 11.5 & 10.5 & 10.3 & 10.1 & 12.4 & 12.1 & 10.5 & 11.4 & 11.2 \\
2000 & 104 & 94 & 93 & 91 & 112 & 109 & 94 & 102 & 101 \\
\hline \hline
\end{tabular}

With one very notable exception, the cumulative table seems to confirm the trends visible from a Term-by-Term application of the modified median measure. Justice Kennedy, Justice Souter, and Chief Justice Rehnquist lead the Court, though not by substantial margins. As in so many other measures, Justice Thomas has improved over seven Terms, while Justice Ginsburg has faded. Justice Ginsburg's fifty-two-point lead over Justice Thomas in JQ has now shrunk to eight points. Finally, like our naive and sophisticated indexes, the cumulative version of the modified median measure does not merely represent the average of its yearly results. Though Justice Stevens trails Justice O'Connor in every Term, he has finished tied with or ahead of Justice O'Connor in the cumulative modified median measure since the end of October Term 1998.

Like its close cousin, Baker's standard measure, the modified median measure exhibits a strong regression toward the mean. At the end of seven Terms, eight of nine Justices are clustered within a tenth of their expected voting power. The ninth, Justice Kennedy, exceeds that margin by two points of JQ. Within this narrow band, Justice Kennedy, Justice Souter, Chief Justice Rehnquist, and Justice Ginsburg cast slightly 
weightier votes than do their colleagues. Only a few paces behind this pack, Justice Breyer has straddled par as tightly as anyone plausibly can. He has not deviated more than a single point from the $100 \mathrm{JQ}$ benchmark since the 1997 Term.

The overwhelming trend in this table nevertheless remains that of regression toward the mean. With the trivial exception of Justice O'Connor, whose final index of 10.3 matches her power rating after October Term 1994, the ratings for every Justice crept over time toward the benchmarks of 11.1 index points and 100 in $\mathrm{JQ}$.

Justice O'Connor's performance in the modified median measure, however, is very significant in distinguishing this index from Baker's standard measure. For the sake of convenience, we reproduce the "bottom line" from both indexes-that is, their cumulative results after seven Terms:

Table 14: Baker's Standard Measure Versus Modified Median Measure; Cumulative Results, 1994-2000 Terms

\begin{tabular}{|c|c|c|c|c|c|c|c|c|c||}
\hline Index & CJ & JPS & SOC & AS & AMK & DHS & CT & RBG & SGB \\
\hline Baker & 11.8 & 9.6 & 12.1 & 10.6 & 12.5 & 11.3 & 10.6 & 10.9 & 10.7 \\
standard & 106 & 87 & 109 & 95 & 113 & 101 & 96 & 98 & 96 \\
\hline Modified & 11.5 & 10.5 & 10.3 & 10.1 & 12.4 & 12.1 & 10.5 & 11.4 & 11.2 \\
median & 104 & 94 & 93 & 91 & 112 & 109 & 94 & 102 & 101 \\
\hline
\end{tabular}

Recall that the difference between Baker's standard measure and the modified median measure is simply the latter's exclusion of multiple cases decided by the same coalition. The two likeliest margins in the Supreme Court's decisions, perhaps paradoxically, are 9-0 and 5-4. ${ }^{114}$ Unanimous decisions say nothing about relative differences in voting power among the Justices. Even for scholars who share Professor Baker's assumption that the Justices vote along a single ideological dimension, ${ }^{115}$ the inclusion of unanimous decisions undermines

114. See Edelman \& Sherry, supra note 35, at 1226 \& n.3 (ranking unanimous decisions most frequent in the Court's docket and 5-4 decisions second in frequency).

115. See Richard B. Wilkins et al., Supreme Court Voting Behavior: 1998 Term, 27 HASTINGS CONST. L.Q. 423, 423-24 (2000) (conducting an annual study "to determine whether individual Justices and the Court as a whole are voting more 'conservatively,' more liberally,' or about the same as compared with past Terms"). 
confidence in a quantitative analysis of Supreme Court behavior. ${ }^{116}$ Five-Justice majorities, by contrast, say quite a bit; Professor Baker merely quibbles with us over the weight to accord those decisions. All this is a convoluted way of saying that much, perhaps most, of the docket bias in Baker's standard measure rests in the multiple crediting of five-Justice majorities that decide many cases. That much is clear from the pronounced ideological profile of Baker's decision method. In other words, the modified median measure is in practical terms (if not mathematically precise terms) the equivalent of Baker's standard measure minus much of the docket bias embodied in Baker's decision method.

Given their close kinship, it comes as no surprise that these indexes generate such similar results. After seven Terms, Baker's standard measure and the modified median measure reach almost identical conclusions. Eight of nine Justices come within ten points of JQ in the two indexes.

The exception, of course, is Sandra Day O'Connor. In the transition from Baker's standard measure to the modified median measure, Justice O'Connor drops nearly two points of power, or sixteen points of JQ. She drops from the position of First Runner-Up in Baker's standard measure to eighth place in the modified median measure. Every other member of the contemporary Court's celebrated conservative coalition loses some power, but Justice O'Connor is alone in suffering power losses of this magnitude. In the modified median measure visà-vis Baker's standard measure, the losses in JQ for Chief Justice Rehnquist, and Justices Scalia, Kennedy, and Thomas respectively are two, four, one, and two. Those losses account for a bare third of the JQ gains realized by Justices Stevens, Souter, Ginsburg, and Breyer: seven, eight, four, and five. The rest of the difference comes at Justice O'Connor's expense.

In short, Justice O'Connor, more than any other Justice, has been drawing much of her apparent power from the content of the Court's docket. Were the Supreme Court presented with a different set of legal issues, one should expect Justice O'Connor to be significantly less supple than any of her colleagues in the Court's moderate-to-conservative wing. For us, the modified median measure has the happy coincidence of confirming the naive and sophisticated indexes' conclusion that Justice O'Connor is a relatively weak member of the Supreme

116. See id. at 429 (conceding that such an "analytical scheme is not perfect"). 
Court.

For methodological purposes, the contrast between these indexes suggests that the modified median measure should be favored over Baker's standard measure. The inclusion of so many unanimous decisions dilutes the value of Baker's standard measure. Moreover, Justice O'Connor's performance demonstrates how the pronounced bias in the Court's docket overwhelms and ultimately discredits Baker's decision method. Insofar as the modified median measure represents the best of Baker's standard measure, stripped of the baneful influence of her decision method, it outperforms those other means of identifying the Supreme Court's median Justice.

\section{HANDICAPPING THE POWER PAGEANT: A HALFTIME REPORT}

Whether derived from Banzhaf's index of voting power or some sort of quest for the "median Justice," the measures we have studied reach some degree of agreement. Justices Kennedy and Souter, followed somewhat remotely by the Chief Justice, form the Court's elite: 
Table 15: Power Pageant Finalists-A Summary

\begin{tabular}{|c|c|c|c|c|c|}
\hline Rank & $\begin{array}{l}\text { Naive } \\
\text { index }\end{array}$ & $\begin{array}{c}\text { Sophist- } \\
\text { icated } \\
\text { index }\end{array}$ & $\begin{array}{l}\text { Baker's } \\
\text { standard } \\
\text { measure }\end{array}$ & $\begin{array}{l}\text { Baker's } \\
\text { decision } \\
\text { method }\end{array}$ & $\begin{array}{l}\text { Modified } \\
\text { median } \\
\text { measure }\end{array}$ \\
\hline $\begin{array}{l}\text { 1st: Most } \\
\text { Dangerous } \\
\text { Justice }\end{array}$ & $\begin{array}{l}\text { Kennedy } \\
14.1 \quad 126\end{array}$ & $\begin{array}{l}\text { Souter } \\
18.8169\end{array}$ & $\begin{array}{l}\text { Kennedy } \\
12.5113\end{array}$ & $\begin{array}{l}\text { Kennedy } \\
15.6140\end{array}$ & $\begin{array}{l}\text { Kennedy } \\
12.4112\end{array}$ \\
\hline $\begin{array}{l}\text { 2d:First } \\
\text { Runner-Up }\end{array}$ & $\begin{array}{l}\text { Souter } \\
12.4 \quad 112\end{array}$ & $\begin{array}{l}\text { Kennedy } \\
14.1 \quad 127\end{array}$ & $\begin{array}{l}\text { O'Connor } \\
12.1 \quad 109\end{array}$ & $\begin{array}{l}\text { O'Connor } \\
14.5131\end{array}$ & $\begin{array}{l}\text { Souter } \\
12.1 \quad 109\end{array}$ \\
\hline $\begin{array}{l}\text { 3d: Mr. or } \\
\text { Ms. Con- } \\
\text { geniality }\end{array}$ & $\begin{array}{l}\text { Rehnquist } \\
11.9107\end{array}$ & \multirow[t]{4}{*}{$\begin{array}{l}\text { 4-way tie: } \\
\text { Rehnquist } \\
\text { Scalia } \\
\text { Thomas } \\
\text { Breyer } \\
10.695\end{array}$} & $\begin{array}{l}\text { Rehnquist } \\
11.8106\end{array}$ & $\begin{array}{l}\text { Rehnquist } \\
12.9116\end{array}$ & $\begin{array}{l}\text { Rehnquist } \\
11.5104\end{array}$ \\
\hline $4^{\text {th }}$ & \multirow[t]{3}{*}{$\begin{array}{l}\text { 3-way tie: } \\
\text { Stevens } \\
\text { Ginsburg } \\
\text { Breyer } \\
11.4 \quad 102\end{array}$} & & $\begin{array}{l}\text { Souter } \\
11.3101\end{array}$ & $\begin{array}{l}\text { Thomas } \\
12.0 \quad 108\end{array}$ & $\begin{array}{l}\text { Ginsburg } \\
11.4 \quad 102\end{array}$ \\
\hline $5^{\text {th }}$ & & & $\begin{array}{l}\text { Ginsburg } \\
10.998\end{array}$ & $\begin{array}{l}\text { Scalia } \\
11.7 \quad 105\end{array}$ & $\begin{array}{l}\text { Breyer } \\
11.2101\end{array}$ \\
\hline $6^{23}$ & & & $\begin{array}{l}\text { Breyer } \\
10.796\end{array}$ & $\begin{array}{l}\text { Souter } \\
8.6 \quad 77\end{array}$ & $\begin{array}{l}\text { 2-way tie: } \\
\text { Stevens } \\
\text { Thomas } \\
10.594\end{array}$ \\
\hline $7^{\text {th }}$ & \multirow[t]{2}{*}{$\begin{array}{l}\text { 2-way tie: } \\
\text { O'Connor } \\
\text { Thomas } \\
9.788\end{array}$} & $\begin{array}{l}\text { O'Connor } \\
9.4 \quad 85\end{array}$ & $\begin{array}{l}\text { Thomas } \\
10.696\end{array}$ & \multirow[t]{2}{*}{$\begin{array}{l}\text { 2-way tie: } \\
\text { Ginsburg } \\
\text { Stevens } \\
8.3 \quad 75\end{array}$} & \\
\hline $8^{4 b}$ & & $\begin{array}{l}\text { Ginsburg } \\
8.274\end{array}$ & $\begin{array}{l}\text { Scalia } \\
10.695\end{array}$ & & $\begin{array}{l}\text { O'Connor } \\
10.393\end{array}$ \\
\hline $9^{42}$ & $\begin{array}{l}\text { Scalia } \\
8.1 \quad 73\end{array}$ & $\begin{array}{l}\text { Stevens } \\
7.1 \quad 64\end{array}$ & $\begin{array}{l}\text { Stevens } \\
9.6 \quad 87\end{array}$ & $\begin{array}{l}\text { Breyer } \\
8.1 \quad 73\end{array}$ & $\begin{array}{l}\text { Scalia } \\
10.191\end{array}$ \\
\hline
\end{tabular}


Presenting the final results of all five measures enables us to see the Power Pageant from another perspective:

Table 16: Another View of the Power Pageant

\begin{tabular}{||l|c|c|c|c|c|c|c|c|c||}
\hline Index & CJ & JPS & SOC & AS & AMK & DHS & CT & RBG & SGB \\
\hline Naive & 11.9 & 11.4 & 9.7 & 8.1 & 14.1 & 12.4 & 9.7 & 11.4 & 11.4 \\
& 107 & 102 & 88 & 73 & 126 & 112 & 88 & 102 & 102 \\
\hline Sophist- & 10.6 & 7.1 & 9.4 & 10.6 & 14.1 & 18.8 & 10.6 & 8.2 & 10.6 \\
icated & 95 & 64 & 85 & 95 & 127 & 169 & 95 & 74 & 95 \\
\hline Baker & 11.8 & 9.6 & 12.1 & 10.6 & 12.5 & 11.3 & 10.6 & 10.9 & 10.7 \\
standard & 106 & 87 & 109 & 95 & 113 & 101 & 96 & 98 & 96 \\
\hline Baker & 12.9 & 8.3 & 14.5 & 11.7 & 15.6 & 8.6 & 12.0 & 8.3 & 8.1 \\
decision & 116 & 75 & 131 & 105 & 140 & 77 & 108 & 75 & 73 \\
\hline Modified & 11.5 & 10.5 & 10.3 & 10.1 & 12.4 & 12.1 & 10.5 & 11.4 & 11.2 \\
median & 104 & 94 & 93 & 91 & 112 & 109 & 94 & 102 & 101 \\
\hline
\end{tabular}

Notably, Justice Kennedy, Justice Souter, and Chief Justice Rehnquist are the only three contestants who achieved topthree finishes in at least three out of five indexes. These three are also the only Justices to attract more than their expected share of power-that is, power indexes greater than or equal to 11.1 and JQs greater than or equal to 100 -in at least four measures. We believe that these three jurists, and only these three, qualify as finalists in the Power Pageant of the Justices.

Our indexes and Professor Baker's differ radically on the question of Sandra Day O'Connor. We simply do not share Professor Baker's enthusiasm for Justice O'Connor. Justice O'Connor fares no better than seventh in our measures, substantially below the benchmark for an average Justice. She excels, however, in Professor Baker's standard and decision measures, finishing a strong second in these indexes. As we have noted, both of these indexes heavily reflect the content of the Court's docket. The modified median measure, which resembles our indexes in counting each unique coalition only once but is in all other respects the methodological cousin of Professor Baker's measures, places Justice O'Connor in eighth place.

Professor Baker's decision method stands out among these indexes. We have already noted how cleanly it segregates the Justices by ideology. The five most conservative members of 
the Court all wield more than their expected share of power, while the four most liberal Justices are mired within two points of seventy-five in JQ.

If this index is set aside, the other power rating systems reach a rough consensus on Justices Thomas, Ginsburg, and Breyer. With minor variations among the indexes, the three most junior Justices occupy the middle of the power ratings. Thanks to her strong fourth place finishes in our naive index and in the modified median measure, Justice Ginsburg seems marginally stronger than Justice Breyer. He in turn outranks Justice Thomas. The exception to this trend is the sophisticated index, which rates Justice Ginsburg a lowly eighth.

These figures, however, obscure movement within the ratings over the course of seven Terms. Justice Ginsburg finished out of the money in all indexes despite winning the title of Most Dangerous Justice for the 1995 Term. Despite his abysmal start, Justice Thomas gained strength in every measure and came within a hair of securing no less than nine-tenths of his expected voting power in every index.

Justices Scalia and Stevens appear to be the Court's weakest Justices. Each scores a distant last in one of our indexes. Though the margins are narrower, the two median Justice measures not wholly distorted by the Court's docket-namely, Baker's standard measure and the modified median measurerate Justices Stevens and Scalia no higher than sixth.

The indexes themselves do not survive the Power Pageant altogether unscathed. Our generalized Banzhaf index has proved useless as a long-run measure of voting power. It generates so much information that it cannot identify differences in voting power on a Court whose Justices are ideologically riven and far from equal in their coalition-building aptitudes. Professor Baker's decision method is so transparently dependent on the Court's docket that its results can scarcely be trusted. Among the remaining measures designed to find the median Justice, we prefer the modified median measure because it, unlike Baker's standard measure, avoids the decision method's fatal technique of counting multiple instances of each observed coalition.

But this game continues. Chief Justice Rehnquist, Justice Kennedy, and Justice Souter are awaiting the announcement of the Most Dangerous Justice. Reluctant to conclude the Power Pageant without consulting some non-quantitative measures of relative voting strength, we now turn to the set of indirect 
measures that we consulted in our original 1996 study.

\section{INDIRECT MEASURES OF VOTING POWER}

Relying exclusively on the Harvard Law Review's annual survey of the Supreme Court, we will reprise three of the indirect measures of voting power that we considered in The Most Dangerous Justice. In turn we will count the number of 5-4 cases decided by particular coalitions, consider the number and significance of 5-4 opinions written by each Justice, and examine overall voting alignments among the Justices. The most recent Harvard Law Review survey available to us covered the 1999 Term. As this article went to press, the Harvard Law Review had yet to analyze the 2000 Term. Though we will not attempt to duplicate Harvard's calculation of overall voting alignments, we will rely on a leading journalist's overview of the 2000 Term to emulate Harvard's survey of putatively significant cases. In her annual Supreme Court roundup for the New York Times, ${ }^{117}$ Linda Greenhouse analyzed twenty-six cases, fifteen of which would fit Harvard's definition of a 5-4 margin. ${ }^{118}$ We found an additional twelve cases that, in our judgment, would satisfy Harvard's definition of a 5-4 decision. 119

117. Linda Greenhouse, In Year of Florida Vote, Supreme Court Also Did Much Other Work, N.Y. TIMES, July 2, 2001, at A12.

118. The fifteen cases decided by a 5-4 margin in the Greenhouse survey were Zaduydas v. Davis, 121 S. Ct. 2491 (2001) (Breyer, J.); Palazzolo v. Rhode Island, 121 S. Ct. 2448 (2001) (Kennedy, J.); Lorillard Tobacco Co. v. Reilly, 121 S. Ct. 2404 (2001) (O'Connor, J.); FEC v. Colorado Republican Federal Campaign Commission, 121 S. Ct. 2351 (2001) (Souter, J.); INS v. Saint Cyr, 121 S. Ct. 2271 (2001) (Stevens, J.); Nguyen v. INS, 121 S. Ct. 2053 (2001) (Kennedy, J.); Kyllo v. United States, 121 S. Ct. 2038 (2001) (Scalia, J.); Alexander v. Sandoval, 121 S. Ct. 1511 (2001) (Scalia, J.); Atwater v. City of Lago Vista, 121 S. Ct. 1536 (2001) (Souter, J.); Hunt v. Cromartie, 121 S. Ct. 1452 (2001) (Breyer, J.); Circuit City Stores, Inc. v. Adams, 121 S. Ct. 1302 (2001) (Kennedy, J.); Legal Services Corp. v. Velazquez, 121 S. Ct. 1043 (2001) (Kennedy, J.); Board of Trustees of the University of Alabama v. Garrett, $121 \mathrm{~S}$. Ct. 955 (2001) (Rehnquist, C.J.); Solid Waste Agency v. United States Army Corps of Engineers, 121 S. Ct. 675 (2001) (Rehnquist, C.J.); Bush v. Gore, 121 S. Ct. 525 (2000) (per curiam).

119. See Tyler v. Cain, 121 S. Ct. 2478 (2001) (Thomas, J.); Calcano-Martinez v. INS, 121 S. Ct. 2268 (2001) (Stevens, J.); Idaho v. United States, 121 S. Ct. 2135 (2001) (Souter, J.); NLRB v. Ky. River Cmty. Care, Inc., 121 S. Ct. 1861 (2001) (Scalia, J.); Buckhannon Bd. \& Home, Inc., v. W. Va. Dep't of Health \& Human Res., 121 S. Ct. 1835 (2001) (Rehnquist, C.J.); Rogers v. Tennessee, 121 S. Ct. 1693 (2001) (O'Connor, J.); Daniels v. United States, 121 S. Ct. 1578 (2001) (O'Connor, J.); Lackawanna County Dist. Attorney v. Cross, 121 S. Ct. 1567 (2001) (O’Connor, J.); Texas v. Cobb, 121 S. Ct. 1335 (2001) (Rehnquist, 


\section{Number of Cases Decided by Particular Coalitions}

Although all of our measures of voting power ignore the frequency with which certain groups of Justices align, we have acknowledged that "the number of cases decided by particular coalitions" may "rank high in any pragmatic assessment of the Court." 120 The number of times a Justice prevails over the course of a Term or of several Terms is the cornerstone of Professor Baker's standard measure. ${ }^{121}$ In fact, she goes so far as to prescribe the strategy of "join[ing] the winning coalition more often than the other Power Pageant contestants" as "the route to victory." 22 By contrast, we believe that "the habit of voting with the majority does not, standing alone, determine a Justice's influence." ${ }^{123}$ We therefore prefer to think of the frequency of victory as an informal "plus factor." 124

Apart from any considerations of accuracy, this measure does reveal some differences among the Justices. Relying exclusively on the Harvard Law Review's tally of 5-4 decisions from the 1994 Term to the 1999 Term and on our own application of Harvard's criteria to the 2000 Term, we discovered a lopsided distribution of decisions among thirty five-Justice coalitions: ${ }^{125}$

C.J.); Brentwood Acad. v. Tenn. Secondary Sch. Athletic Ass'n, 121 S. Ct. 924 (2001) (Souter, J.); Green Tree Fin. Corp. v. Randolph, 121 S. Ct. 513 (2000) (Rehnquist, C.J.); Bush v. Gore, 121 S. Ct. 512 (2000) (per curiam).

In her tally of 5-4 decisions, Greenhouse reported twenty-six rather than twenty-seven. Greenhouse, supra note 117, at A12. In all likelihood, the decision she would exclude is the stay decision in Bush v. Gore, $121 \mathrm{~S}$. Ct. 512 (2000), which consisted of a minimalist per curiam opinion, a full concurrence by Justice Scalia, and a full dissent by Justice Stevens for himself and Justices Souter, Ginsburg, and Breyer. The alignment of this case was repeated in a key portion of the decision on the merits in Bush v. Gore, $121 \mathrm{~S}$. Ct. 525 (2000), as well as thirteen other cases decided during October Term 2000. The inclusion vel non of the stay decision has minimal impact on our overall analysis.

120. Dangerous Justice, supra note 1, at 86-87.

121. See Baker, supra note 2, at 202.

122. Id. at 208.

123. Sultans of Swing, supra note 3, at 221.

124. Dangerous Justice, supra note 1 , at 86.

125. For similar assessments of the Court's recent 5-4 decisions, see Linda Greenhouse, Divided They Stand: The High Court and the Triumph of Discord, N.Y. TIMES, July 15, 2001, \$ 4, at 1; Jonathan Ringel, What the High Court Says When It Votes 5-4, LEGAL TMIES, Dec. 18, 2000, at 14. 
Table 17: Number of Cases Decided by Specific Five-Justice Coalitions; 5-4 Decisions Only, 1994-2000 Terms

\begin{tabular}{||l|c|}
\hline \multicolumn{1}{|c|}{ Five-Justice coalitions } & Cases decided \\
\hline Rehnquist, O'Connor, Scalia, Kennedy, Thomas & 58 \\
\hline Stevens, O'Connor, Souter, Ginsburg, Breyer & 15 \\
\hline Stevens, Kennedy, Souter, Ginsburg, Breyer & 13 \\
\hline Rehnquist, Scalia, Kennedy, Thomas, Ginsburg & 3 \\
\hline Rehnquist, Stevens, Scalia, Kennedy, Thomas & 2 \\
\hline Rehnquist, O'Connor, Kennedy, Thomas, Breyer & 2 \\
\hline Rehnquist, Scalia, Kennedy, Souter, Thomas & 2 \\
\hline Stevens, O'Connor, Kennedy, Souter, Breyer & 2 \\
\hline Stevens, O'Connor, Kennedy, Ginsburg, Breyer & 2 \\
\hline Stevens, Scalia, Souter, Thomas, Ginsburg & 2 \\
\hline Rehnquist, Stevens, O'Connor, Kennedy, Souter & 1 \\
\hline Rehnquist, Stevens, O'Connor, Souter, Ginsburg & 1 \\
\hline Rehnquist, Stevens, Kennedy, Souter, Breyer & 1 \\
\hline Rehnquist, Stevens, Kennedy, Ginsburg, Breyer & 1 \\
\hline Rehnquist, Stevens, Souter, Ginsburg, Breyer & 1 \\
\hline Rehnquist, O'Connor, Scalia, Kennedy, Breyer & 1 \\
\hline Rehnquist, O'Connor, Scalia, Souter, Thomas & 1 \\
\hline Rehnquist, O'Connor, Scalia, Thomas, Ginsburg & 1 \\
\hline Rehnquist, O'Connor, Scalia, Thomas, Breyer & 1 \\
\hline Rehnquist, O'Connor, Kennedy, Souter, Ginsburg & 1 \\
\hline Rehnquist, O'Connor, Souter, Ginsburg, Breyer & 1 \\
\hline Stevens, O'Connor, Kennedy, Thomas, Breyer & 1 \\
\hline Stevens, O'Connor, Souter, Thomas, Ginsburg & 1 \\
\hline Stevens, Scalia, Kennedy, Souter, Thomas & 1 \\
\hline Stevens, Scalia, Kennedy, Souter, Ginsburg & 1 \\
\hline Stevens, Scalia, Souter, Thomas, Breyer & 1 \\
\hline Stevens, Kennedy, Souter, Thomas, Ginsburg & 1 \\
\hline Stevens, Souter, Thomas, Ginsburg, Breyer & 1 \\
\hline O'Connor, Kennedy, Souter, Ginsburg, Breyer & 1 \\
\hline Scalia, Souter, Thomas, Ginsburg, Breyer & 1 \\
\hline
\end{tabular}

The conservative bloc of Chief Justice Rehnquist and Jus- 
tices O'Connor, Scalia, Kennedy, and Thomas rendered nearly half of the Court's 121 five-to-four decisions during these seven Terms. This quintet has decided so many prominent cases, including Bush v. Gore, ${ }^{126}$ that it has acquired its own social meaning. ${ }^{127}$ Recent work by Brian Lowe allows a more detailed look at this coalition. The interactive program at Lowe's website $^{123}$ uses our data to measure the power of each Justice within a particular coalition. For a fixed coalition of Justices, Lowe defines the power of a Justice within that coalition to be the number of alliances he or she can form with Justices outside that coalition. The program then computes the relative power of Justices within that coalition. Lowe's methodology blends aspects of our approach and of Professor Baker's. Like us, Lowe tries to measure the propensity of each Justice to form coalitions with different colleagues. Like Professor Baker, he counts multiple instances of each coalition. This trait enables his program to report the most common coalition containing any particular combination of Justices.

Lowe's work also supports our hypothesis that Justice O'Connor draws more of her power than does any other Justice strictly from the distribution of cases in the Court's docket. Lowe's results for the conservative bloc show that Justice O'Connor holds thirty-one percent of the power within this coalition, followed in order by Justice Kennedy, Justice Scalia, Justice Thomas, and Chief Justice Rehnquist with twenty-four, twenty, seventeen, and eight percent respectively. The dominance of the conservative bloc, combined with Justice O'Connor's prominence within that coalition, goes a long way toward explaining the popular perception that Justice O'Connor is extremely powerful.

Across the entire spectrum of 5-4 decisions, certain coalitions are far likelier to emerge. The three most frequently observed coalitions-the conservative bloc and two alliances consisting of Justices Stevens, Souter, Ginsburg, and Breyer plus either Justice O'Connor or Justice Kennedy-accounted for more than two-thirds of the Court's single-vote decisions. No other coalition decided more than three cases, and twenty of thirty distinct five-Justice blocs decided a single case.

126. 121 S. Ct. 525 (2000) (per curiam).

127. See generally Lawrence Lessig, The Regulation of Social Meaning, $62 \mathrm{U}$. CHI. L. REV. 943 (1995).

128. Brian Lowe, Most Powerful Justice, at http:/law.vanderbilt.edu/faculty/ edelman/php_mpj (last visited Oct. 5, 2001). 
Given the prominence of their alliance in the Court's recent history, the members of the conservative bloc participated in more winning coalitions than did their comparatively liberal colleagues:

Table 18: Number of Times Each Justice Prevailed in 5-4 Decisions

\begin{tabular}{|l|c|c|}
\hline \multicolumn{1}{|c|}{ Justice } & Number of cases & Winning percentage \\
\hline Kennedy & 94 & $77.7 \%$ \\
\hline O'Connor & 90 & $74.4 \%$ \\
\hline Rehnquist & 78 & $64.5 \%$ \\
\hline Thomas & 78 & $64.5 \%$ \\
\hline Scalia & 75 & $62.0 \%$ \\
\hline Souter & 49 & $40.5 \%$ \\
\hline Stevens & 47 & $38.8 \%$ \\
\hline Ginsburg & 47 & $38.8 \%$ \\
\hline Breyer & 45 & $37.2 \%$ \\
\hline
\end{tabular}

No Justice outside the conservative bloc tasted victory in a majority of the Court's 5-4 decisions. Justice Scalia, who enjoyed fewer wins than any other member of the conservative bloc, was more than half again as likely as Justice Souter to prevail in a 5-4 situation.

Within the conservative bloc, two members stand out. Justices O'Connor and Kennedy were significantly more likely than Chief Justice Rehnquist, Justice Scalia, or Justice Thomas to participate in a winning five-Justice coalition. The disparity is easily explained. Justice O'Connor abandoned the conservative bloc fifteen times over seven Terms to form winning alliances with Justices Stevens, Souter, Ginsburg, and Breyer. Justice Kennedy did so thirteen times over the same span. We therefore award the first tiebreaker to Justices O'Connor and Kennedy.

2. Number and Significance of 5-4 Opinions Written by Individual Justices

The number and putative importance of opinions written in 5-4 cases may also shed some light on individual Justices' rela- 
tive voting power. ${ }^{129}$ We refer again to the Harvard Law Review's statistical analyses of the Supreme Court. In its annual review of the previous Term, Harvard not only counts 5-4 decisions but also compiles an informal, highly subjective list of "greatest hits." 130 By tradition, a professional author writes a comment on the previous Term's most significant decision or cluster of decisions. The student editors then write brief notes on roughly twenty-five other decisions. With remarkable consistency over time, Harvard devotes extended commentary, whether written by a professional or a student, to slightly more than half of the cases it identifies as having been decided by a 5-4 margin. The Greenhouse survey of the 2000 Term shares a practically identical profile: twenty-six cases worthy of analysis, among them fifteen of the twenty-seven cases decided by a 5-4 margin.

The following table reports authorship of 5-4 decisions by individual Justices. The first number in each cell indicates the number of five-Justice majority opinions by a Justice in a particular Term. The second number refers to the number of majority opinions within the subset of 5-4 cases that merited either a professional comment or a student case note in the Harvard Law Review's survey of Supreme Court Terms 1994 through 1999 or a mention in Linda Greenhouse's roundup of the 2000 Term. The greater the second number relative to the first, the greater the likelihood that the Justice in question has written a 5-4 decision in a noteworthy case:

129. See Dangerous Justice, supra note 1 , at 88-89.

130. See generally Saul Brenner, Measuring the Importance of Supreme Court Decisions, 90 LAW LIBR. J. 183 (1998) (concluding that there are no uniformly reliable measures of the importance of Supreme Court decisions). 
Table 19: Authorship of 5-4 Decisions, Including "Significant" Decisions

\begin{tabular}{|c|c|c|c|c|c|c|c|c|}
\hline Term & 1994 & 1995 & 1996 & 1997 & 1998 & 1999 & 2000 & Total \\
\hline CJ & $3 / 3$ & $4 / 2$ & $2 / 1$ & $1 / 0$ & $1 / 1$ & $5 / 3$ & $5 / 2$ & $\begin{array}{c}21 / 12 \\
57 \% \\
\end{array}$ \\
\hline JPS & $2 / 2$ & $2 / 2$ & $2 / 2$ & $1 / 1$ & $1 / 0$ & $2 / 1$ & $2 / 1$ & $\begin{array}{l}12 / 7 \\
58 \% \\
\end{array}$ \\
\hline SOC & $2 / 2$ & $0 / 0$ & $2 / 1$ & $3 / 3$ & $3 / 3$ & $2 / 2$ & $4 / 1$ & $\begin{array}{c}16 / 12 \\
75 \% \\
\end{array}$ \\
\hline AS & $0 / 0$ & $1 / 0$ & $2 / 1$ & $1 / 0$ & $2 / 2$ & $1 / 1$ & $3 / 2$ & $\begin{array}{l}10 / 6 \\
60 \% \\
\end{array}$ \\
\hline AMK & $5 / 3$ & $0 / 0$ & $4 / 1$ & $3 / 3$ & $3 / 3$ & $2 / 0$ & $4 / 4$ & $\begin{array}{c}21 / 14 \\
67 \% \\
\end{array}$ \\
\hline DHS & $1 / 0$ & $0 / 0$ & $3 / 1$ & $0 / 0$ & $2 / 0$ & $0 / 0$ & $4 / 2$ & $\begin{array}{l}10 / 3 \\
30 \% \\
\end{array}$ \\
\hline $\mathbf{C T}$ & $0 / 0$ & $0 / 0$ & $2 / 1$ & $3 / 1$ & $1 / 0$ & $3 / 0$ & $1 / 0$ & $\begin{array}{l}10 / 2 \\
20 \% \\
\end{array}$ \\
\hline RBG & $3 / 1$ & $2 / 1$ & $0 / 0$ & $0 / 0$ & $0 / 0$ & $0 / 0$ & $0 / 0$ & $\begin{array}{c}5 / 2 \\
40 \% \\
\end{array}$ \\
\hline SGB & $0 / 0$ & $0 / 0$ & $1 / 1$ & $3 / 2$ & $2 / 0$ & $3 / 2$ & $2 / 2$ & $\begin{array}{l}11 / 7 \\
64 \% \\
\end{array}$ \\
\hline $\begin{array}{c}\text { Per } \\
\text { Curiam } \\
\end{array}$ & $0 / 0$ & $2 / 0$ & $0 / 0$ & $0 / 0$ & $1 / 0$ & $0 / 0$ & $2 / 1$ & $\begin{array}{r}5 / 1 \\
20 \% \\
\end{array}$ \\
\hline Total & $16 / 11$ & $11 / 5$ & $18 / 9$ & $15 / 10$ & $16 / 9$ & $18 / 9$ & $27 / 15$ & $\begin{array}{c}121 / 68 \\
56 \%\end{array}$ \\
\hline
\end{tabular}

This table reflects several striking patterns. Four Justices-Chief Justice Rehnquist and Justices Stevens, O'Connor, and Kennedy-account for authorship of seventy of the 121 one-vote decisions at issue (57.9\%), including forty-five of the sixty-eight most significant (66.2\%). Put somewhat differently, four of the Court's five most senior members wrote nearly three-fifths of the Court's 5-4 decisions and nearly two-thirds of the significant cases decided by a 5-4 vote. By contrast, the four most junior Justices-Souter, Thomas, Ginsburg, Breyerproduced a relatively modest total of thirty-six majority opinions in 5-4 cases (29.8\%), including an even smaller share (four- 
teen opinions, or $20.6 \%$ ) of significant 5-4 cases. At an average of nine opinions, including 3.5 opinions in significant cases, the most junior Justices more closely resemble "Per Curiam, J.," than they resemble Justice O'Connor, Justice Kennedy, or Chief Justice Rehnquist.

The stark contrast between the Court's senior and junior members highlights the power of assignment. "The significance of opinion assignments cannot be overstated,"131 for "the power to select the author" of an opinion equals "the power to determine the general direction of the opinion." ${ }^{32}$ The senior Justice in a winning coalition frequently keeps control of an important case in order to shape the lead opinion. ${ }^{133}$ The preferred strategy shifts when the senior member of a coalition chooses to assign rather than keep an opinion. Chief Justices over time have "dramatically over-assign[ed] to those ideologically close to them and under-assign[ed] to those furthest from them."134 In other cases, however, assignments are designed to prevent the weakest member of a fragile majority from defecting. ${ }^{135}$ Under these circumstances, Justices closer in ideology to the dissent tend to collect the lion's share of opinion assignments. ${ }^{136}$

Power over opinion assignments varies strictly according to seniority. If all coalitions are equally likely, without regard to coalitional dynamics or the Court's docket, then mathematics alone dictates the probability that a Justice will assign an opinion. By definition the four most junior Justices have no chance

131. Dangerous Justice, supra note 1, at 99. See generally Forrest Maltzman \& Paul J. Wahlbeck, May It Please the Chief? Opinion Assignments in the Rehnquist Court, 40 AM. J. POL. SCI. 421 (1996).

132. WOODWARD \& ARMSTRONG, supra note 65 , at 65.

133. See JefFrey A. Segal \& Harold J. SPAETH, THE SuPREME CourT aND THE ATTTUDINAL MODEL 271-72 (1993).

134. Id. at 268; see also LAWRENCE BAUM, THE PUZZLE OF JUDICIAL BEHAVIOR 110-12 (1997). See generally Eugenia F. Toma, A Contractual Model of the Voting Behavior of the Supreme Court: The Role of the Chief Justice, 16 INT'L REV. L. \& ECON. 433 (1996).

135. See, e.g., David W. ROHDE \& HaRolD J. SPAETH, SuPREME CouRT DECISION MAKING 172-92 (1976); Cross, supra note 15, at $517 \&$ n.27; Sue Davis, Power on the Court: Chief Justice Rehnquist's Opinion Assignments, 74 JUDICATURE 66, 67-68 (1990); William P. McLauchlan, Ideology and Conflict in Supreme Court Opinion Assignment, 1946-1962, 25 W. POL. Q. 16, 16-17 (1972).

136. See Saul Brenner, The Shapley-Shubik Power Index and the Supreme Court: A Reply to Professor Johnson, 19 JURIMETRICS J. 167, 169 n.8 (1978); David W. Rohde, Policy Goals, Strategic Choice and Majority Opinion Assignments in the U.S. Supreme Court, 16 MIDWEST J. POL. SCI. 652, 679 (1972). 
of assigning an opinion. Among the five most senior Justices, the theoretical probability of assigning an opinion falls sharply as seniority diminishes. The following table describes the distribution of power over opinion assignments according to the coalition size: ${ }^{137}$

137. To see how the numbers in Table 20 are computed, consider the example of Justice O'Connor. For her to assign an opinion in a 5-4 decision, two conditions must prevail. First, she must vote on the winning side. Second, the other Justices in the majority cannot include either Chief Justice Rehnquist or Justice Stevens, who are senior to her and would assert the assignment privilege ahead of her. Therefore, the other members of the majority must be drawn from the set of six Justices junior to Justice O'Connor-namely, Justices Scalia, Kennedy, Souter, Thomas, Ginsburg, and Breyer. In other words, the number of 5-4 decisions in which Justice O'Connor assigns the opinion is equal to the number of combinations of exactly four Justices drawn from the six-member set consisting of Justices Scalia, Kennedy, Souter, Thomas, Ginsburg, and Breyer.

Recall that the formula for determining the number of combinations of exactly $c$ Justices on a Court of $n$ Justices is $n ! /(c ! \cdot(n-c) !)$. See supra note 68. As the previous discussion reveals, the relevant rump portion of a Court for purposes of determining the instances in which a Justice would assign the opinion is the portion of the Court junior to the assigning Justice. That number is merely $n$ minus $r$, where $r$ represents the rank of the assigning Justice on a scale where the Chief Justice holds rank 1 . If $m$ represents the exact size of the winning coalition in question, an assigning Justice must join with a coalition of exactly $m$ minus 1 colleagues, all of whom are junior to him or her. In other words, we must solve for the number of coalitions that have $m$ minus 1 members on a rump Court of $n$ minus $r$ members. Substituting $(n-r)$ for $n$ and $(m-1)$ for $c$ yields the following formula:

$\frac{(n-r) !}{(m-1) !(n-r-m+1) !}$

We can now return to our original example. The number of times Justice O'Connor, ranked third on a Court of nine Justices, would assign the opinion within a prevailing coalition of five Justices is equal to $(9-3) ! /((5-1)$ ! . $(9-3-5+1) !)$, or $6 ! /(4 ! \cdot 2 !)$, which equals 15 . 
Table 20: Probability of Assigning a Majority Opinion

\begin{tabular}{|c|c|c|c|c|c|c|c||}
\hline Justice & $5-4$ & $6-3$ & $7-2$ & $8-1$ & $9-0$ & Total & $\%$ \\
\hline CJ & 70 & 56 & 28 & 8 & 1 & 163 & 63.7 \\
\hline JPS & 35 & 21 & 7 & 1 & 0 & 64 & 25.0 \\
\hline SOC & 15 & 6 & 1 & 0 & 0 & 22 & 8.6 \\
\hline AS & 5 & 1 & 0 & 0 & 0 & 6 & 2.3 \\
\hline AMKK & 1 & 0 & 0 & 0 & 0 & 1 & 0.4 \\
\hline Total & 126 & 84 & 36 & 9 & 1 & 256 & 100.0 \\
\hline
\end{tabular}

Together, the Chief Justice and the senior Associate Justice hold nearly nine-tenths of the Court's theoretical "assigning power." Within the subset of 126 possible five-Justice combinations, these two members of the Court enjoy a less commanding but nevertheless impressive five-sixths of the theoretical power to assign (105 of 126 combinations).

What we have is not mere hypothesis however, but the actual record of 5-4 decisions rendered by the Supreme Court from October Term 1994 to October Term 2000. Chief Justice Rehnquist led the winning side in seventy-eight of those 121 decisions. Of the remaining forty-three decisions, Justice Stevens was the most senior member of the winning coalition in forty-one; Justices O'Connor and Scalia led the victorious bloc exactly once apiece. We can now compare the Court's theoretical "assigning power" with the cases it actually decided from the 1994 Term through the 2000 Term: 
Table 21: Hypothetical Versus Actual "Assigning Power" in 5-4 Cases

\begin{tabular}{||l|c|c|c|c||}
\hline \hline Justice & $\begin{array}{c}\text { Hypothetical } \\
\text { combina- } \\
\text { tions }\end{array}$ & $\begin{array}{c}\text { Hypothetical } \\
\text { assigning } \\
\text { power }\end{array}$ & $\begin{array}{c}\text { Actual cases } \\
\text { decided, OT } \\
\text { '94 through } \\
\text { OT '99 }\end{array}$ & $\begin{array}{c}\text { Actual assigning } \\
\text { power in 5-4 } \\
\text { cases }\end{array}$ \\
\hline Rehnquist & 70 & $55.6 \%$ & 78 & $64.5 \%$ \\
\hline Stevens & 35 & $27.8 \%$ & 41 & $33.9 \%$ \\
\hline O'Connor & 15 & $11.9 \%$ & 1 & $0.8 \%$ \\
\hline Scalia & 5 & $4.0 \%$ & 1 & $0.8 \%$ \\
\hline Kennedy & 1 & $0.8 \%$ & 0 & $0.0 \%$ \\
\hline
\end{tabular}

From the 1994 Term through the 2000 Term, 56.2\% of 5-4 decisions were considered significant. For every nine opinions written in a 5-4 setting, a Justice should expect five to decide a significant case. The five most senior Justices met or exceeded this standard; their four junior colleagues, except Justice Breyer, fell significantly short of the five-ninths benchmark. But the relevant boundary is not the one that marks the theoretical threshold of power to assign an opinion. It is the line between Justices Stevens and O'Connor. Justice Stevens, as senior Associate Justice, should expect to wield half as much assignment power as the Chief Justice. Justice Stevens in fact outperforms this expectation by a narrow margin. By contrast, Justices O'Connor and Scalia have attained a negligible share of the Court's collective power over opinion assignments. In the lone five-Justice majority that she headed during this sevenTerm stretch, Justice O'Connor assigned Gasperini v. Center for Humanities, Inc. ${ }^{138}$ to Justice Ginsburg during the 1995 Term. (Coincidentally, Justice Ginsburg has not written another opinion for the Court in a 5-4 case since Gasperini.) Justice Scalia, perhaps aware of the precious nature of the opportunity, assigned himself the majority opinion in Kyllo $v$. United States. ${ }^{139}$

In 1996 we speculated that seniority correlated negatively with voting power. We hypothesized that the Chief Justice and

138. 518 U.S. 415 (1996).

139. 121 S. Ct. 2038 (2001). 
the senior Associate Justice, who "hold a virtual monopoly on opinion assignments," setting power" over the more arduous process of acquiring influence as "swing voters."141 By contrast, we thought that "junior Associate Justices, having little or no agenda-setting power," would "maximiz[e] their influence" by "aligning their political preferences with the Court's ideological center of gravity and... developing a supple approach to forming coalitions." 142

What we have observed since 1996 forces us to rethink the relationship between seniority and power. Given the distribution of cases on today's Court, Justices O'Connor and Kennedy have practically no power to assign opinions. Mathematics gives Justice O'Connor nearly one-eighth of the Court's power to assign 5-4 cases; politics eliminates all but a sliver of that power. The Chief Justice and Justice Stevens share almost all of the assignment power, and both have not hesitated to write the lion's share of opinions in important cases decided by a onevote margin. These senior members of the Court dominated the 5-4 blockbusters rated by Harvard as the most significant of the 1994, 1995, and 1999 Terms: U.S. Term Limits, Inc. $v$. Thornton, ${ }_{145}^{143}$ Seminole Tribe v. Florida, ${ }^{144}$ and United States $v$. Morrison. ${ }^{145}$

But Justices O'Connor and Kennedy also write for fiveJustice coalitions, including some of the Court's biggest decisions. If anything, they outperform the Court's most senior members. In particular, Justice O'Connor's apparent propensity to write important 5-4 opinions is nothing short of aston-

140. Dangerous Justice, supra note 1 , at 100.

141. Id. at 101.

142. Id.

143. 513 U.S. 779 (1995) (Stevens, J.); see Kathleen M. Sullivan, The Supreme Court, 1994 Term-Comment: Dueling Sovereignties: U.S. Term Limits, Inc. v. Thornton, 109 HARV. L. REV. 78 (1995). Justice Stevens also wrote what Harvard Law Review rated as the most important case of the 1998 Term, Saenz v. Roe, 526 U.S. 489 (1999). See Laurence H. Tribe, The Supreme Court, 1998 Term-Comment: Saenz Sans Prophecy: Does the Privileges or Immunities Revival Portend the Future-or Reveal the Structure of the Present?, 113 HARV. L. REV. 110 (1999).

144. 517 U.S. 44 (1996) (Rehnquist, C.J.); see Henry Paul Monaghan, The Supreme Court, 1995 Term-Comment: The Sovereign Immunity "Exception," 110 HARV. L. REV. 102 (1996).

145. 529 U.S. 598 (2000) (Rehnquist, C.J.); see Catharine A. MacKinnon, The Supreme Court, 1999 Term-Comment: Disputing Male Sovereignty: On United States v. Morrison, 114 HARV. L. REV. 135 (2000). 
ishing. Twelve of her sixteen opinions in this category since 1994 have merited full analysis in the annual Harvard survey or a mention in Linda Greenhouse's review of the 2000 Term. For his part, Justice Kennedy has written two of the cases that merited professional commentary in the Harvard Law Review's annual Supreme Court issue. ${ }^{146}$ To repeat: Justices O'Connor and Kennedy are indistinguishable from all other Justices who rank behind Justice Stevens. They must be doing something different. Edge to Justices O'Connor and Kennedy, plus credit ex officio to Chief Justice Rehnquist and Justice Stevens for assigning themselves the Court's most prominent opinions.

Beyond seniority, several other patterns bear noting. Despite a strong 2000 Term, ${ }^{147}$ Justice Scalia remains curiously weak on this informal measure of power. Each of the Justices immediately before and after him in seniority, Justices O'Connor and Kennedy, writes two to three times as many 5-4 opinions, including 5-4 opinions in putatively significant cases. Among the junior Justices, Justices Thomas and Breyer have surged in recent years, having composed all of their combined twenty-one opinions in 5-4 cases since October Term 1996 and eighteen of twenty-one since the 1997 Term.

At the other extreme, Justice Ginsburg has been shut out altogether of the Court's 5-4 derby since the end of the 1995 Term. Since October 1996, Justice Ginsburg has lagged behind even Per Curiam, J. It is as if Justice Ginsburg exhausted her powers of persuasion after throttling the Virginia Military Institute's all-male admissions policy in her most celebrated performance. ${ }^{148}$ Lest anonymity fail to get its due, the shadowy Per Curiam has written not only Bush $v$. Gore, ${ }^{149}$ perhaps the most notorious 5-4 decision in recent memory, but also Buckley

146. See Ark. Educ. Television Comm'n v. Forbes, 523 U.S. 666 (1998); City of Boerne v. Flores, 521 U.S. 507 (1997); Michael W. McConnell, The Supreme Court, 1996 Term-Comment: Institutions and Interpretation: A Critique of City of Boerne v. Flores, 111 HARV. L. REV. 153 (1997); Frederick Schauer, The Supreme Court, 1997 Term-Comment: Principles, Institutions, and the First Amendment, 112 HARV. L. REV. 84 (1998). Neither of these cases was decided by a 5-4 margin. Professor Schauer's comment treated Forbes and NEA v. Finley, 524 U.S. 569 (1998) (O'Connor, J.), as the most important decisions of the 1997 Term.

147. During the 2000 Term, Justice Scalia wrote putatively significant opinions in Kyllo v. United States, $121 \mathrm{~S}$. Ct. 2038 (2001), and Alexander $v$. Sandoval, 121 S. Ct. 1511 (2001). He also wrote for a five-Justice coalition in NLRB v. Kentucky River Community Care, Inc., 121 S. Ct. 1861 (2001).

148. See United States v. Virginia, 518 U.S. 515 (1996).

149. 121 S. Ct. 525 (2000) (per curiam). 
$v$. Valeo, ${ }^{150}$ the powerhouse decision written one generation ago that arguably foreordained the bitter resolution of the 2000 election.

3. Compatibility Measured Indirectly Through Voting Alignments

Finally, overall voting alignments provide an indirect way of measuring each Justice's ideological flexibility. A Justice who can ally himself or herself with a relatively large range of colleagues will join more "winning coalitions" and thereby increase his or her opportunities "to cast decisive, lawmaking votes." Review's statistical retrospective on the Supreme Court during the 1990s: ${ }^{152}$

150. 424 U.S. 1 (1976) (per curiam).

151. Dangerous Justice, supra note 1 , at 90.

152. See 1999 Harvard Survey, supra note 59, at 403-04. 
Table 22: Voting Alignments, 1994-1999 Terms

\begin{tabular}{|c|c|c|c|c|c|c|c|c|c|}
\hline OT 94-99 & CJ & JPS & SOC & AS & AMK & DAS & CT & RBG & SGB \\
\hline CJ 94 & & 50.6 & 76.7 & 80.0 & 83.7 & 68.6 & 81.4 & 67.1 & 67.1 \\
\hline CJ 95 & & 49.4 & 79.7 & 82.3 & 78.5 & 67.1 & 82.1 & 65.8 & 58.2 \\
\hline CJ 96 & & 53.5 & 78.8 & 81.4 & 84.9 & 69.8 & 81.4 & 67.4 & 60.5 \\
\hline CJ 97 & & 62.4 & 84.8 & 74.2 & 89.2 & 73.1 & 77.4 & 74.2 & 73.1 \\
\hline CJ 98 & & 39.5 & 82.5 & 81.5 & 81.5 & 59.3 & 87.7 & 51.9 & 56.3 \\
\hline CJ 99 & & 48.1 & 92.2 & 74.0 & 85.7 & 57.1 & 76.6 & 59.7 & 66.2 \\
\hline JPS 94 & 50.6 & & 55.3 & 45.2 & 61.2 & 69.4 & 42.4 & 75.0 & 70.7 \\
\hline JPS 95 & 49.4 & & 59.7 & 45.5 & 64.9 & 70.1 & 44.7 & 72.7 & 74.0 \\
\hline JPS 96 & 53.5 & & 55.3 & 44.2 & 61.6 & 73.3 & 44.2 & 79.1 & 77.9 \\
\hline JPS 97 & 62.4 & & 62.0 & 48.4 & 65.6 & 74.3 & 54.8 & 77.4 & 76.3 \\
\hline JPS 98 & 39.5 & & 46.3 & 44.4 & 46.9 & 67.9 & 37.0 & 74.1 & 70.0 \\
\hline JPS 99 & 48.1 & & 51.9 & 41.6 & 50.6 & 84.4 & 49.4 & 85.7 & 76.6 \\
\hline SOC 94 & 76.7 & 55.3 & & 68.2 & 75.6 & 76.7 & 67.4 & 64.7 & 74.4 \\
\hline SOC 95 & 79.7 & 59.7 & & 72.2 & 78.5 & 78.5 & 71.8 & 68.4 & 74.7 \\
\hline SOC 96 & 78.8 & 55.3 & & 78.8 & 80.0 & 70.6 & 80.0 & 69.4 & 67.1 \\
\hline SOC 97 & 84.8 & 62.0 & & 72.8 & 85.9 & 72.8 & 78.3 & 65.2 & 75.0 \\
\hline SOC 98 & 82.5 & 46.3 & & 77.5 & 80.0 & 68.8 & 75.0 & 62.5 & 68.4 \\
\hline SOC 99 & 92.2 & 51.9 & & 67.5 & 81.8 & 63.6 & 74.0 & 66.2 & 72.7 \\
\hline AS 94 & 80.0 & 45.2 & 68.2 & & 75.3 & 60.0 & 88.2 & 59.5 & 59.3 \\
\hline AS 95 & 82.3 & 45.5 & 72.2 & & 73.4 & 60.8 & 87.2 & 58.2 & 54.4 \\
\hline AS 96 & 81.4 & 44.2 & 78.8 & & 79.1 & 61.6 & 97.7 & 58.1 & 53.5 \\
\hline AS 97 & 74.2 & 48.4 & 72.8 & & 68.8 & 62.4 & 87.1 & 58.1 & 57.0 \\
\hline AS 98 & 81.5 & 44.4 & 77.5 & & 72.8 & 60.5 & 84.0 & 53.1 & 50.0 \\
\hline AS 99 & 74.0 & 41.6 & 67.5 & & 71.4 & 46.8 & 89.6 & 45.5 & 53.2 \\
\hline AMK 94 & 83.7 & 61.2 & 75.6 & 75.3 & & 73.3 & 73.3 & 76.5 & 72.0 \\
\hline AMK 95 & 78.5 & 64.9 & 78.5 & 73.4 & & 74.7 & 69.2 & 75.9 & 68.4 \\
\hline AMK 96 & 84.9 & 61.6 & 80.0 & 79.1 & & 72.1 & 79.1 & 67.4 & 65.1 \\
\hline AMK 97 & 89.2 & 65.6 & 85.9 & 68.8 & & 75.3 & 76.3 & 74.2 & 78.5 \\
\hline AMK 98 & 81.5 & 46.9 & 80.0 & 72.8 & & 63.0 & 72.8 & 61.7 & 60.0 \\
\hline AMK 99 & 85.7 & 50.6 & 81.8 & 71.4 & & 54.5 & 75.3 & 55.8 & 59.7 \\
\hline DHS 94 & 68.6 & 69.4 & 76.7 & 60.0 & 73.3 & & 55.8 & 80.0 & 82.9 \\
\hline DHS 95 & 67.1 & 70.1 & 78.5 & 60.8 & 74.7 & & 57.7 & 83.5 & 88.6 \\
\hline DHS 96 & 69.8 & 73.3 & 70.6 & 61.6 & 72.1 & & 61.6 & 79.1 & 76.7 \\
\hline DHS 97 & 73.1 & 74.3 & 72.8 & 62.4 & 75.3 & & 62.4 & 86.0 & 83.9 \\
\hline DHS 98 & 59.3 & 67.9 & 68.8 & 60.5 & 63.0 & & 55.6 & 84.0 & 78.8 \\
\hline DHS 99 & 57.1 & 84.4 & 63.6 & 46.8 & 54.5 & & 54.5 & 88.3 & 81.8 \\
\hline
\end{tabular}




\begin{tabular}{||l|l|l|l|l|l|l|l|l|l||}
\hline OT 94-99 & CJ & JPS & SOC & AS & AMK & DHS & CT & RBG & SGB \\
\hline CT 94 & 81.4 & 42.4 & 67.4 & 88.2 & 73.3 & 55.8 & & 54.1 & 58.5 \\
CT 95 & 82.1 & 44.7 & 71.8 & 87.2 & 69.2 & 57.7 & & 55.1 & 48.7 \\
CT 96 & 81.4 & 44.2 & 80.0 & 97.7 & 79.1 & 61.6 & & 58.1 & 52.3 \\
CT 97 & 77.4 & 54.8 & 78.3 & 87.1 & 76.3 & 62.4 & & 59.1 & 61.3 \\
CT 98 & 87.7 & 37.0 & 75.0 & 84.0 & 72.8 & 55.6 & & 45.7 & 50.0 \\
CT 99 & 76.6 & 49.4 & 74.0 & 89.6 & 75.3 & 54.5 & & 51.9 & 50.6 \\
\hline RBG 94 & 67.1 & 75.0 & 64.7 & 59.5 & 76.5 & 80.0 & 54.1 & & 82.7 \\
RBG 95 & 65.8 & 72.7 & 68.4 & 58.2 & 75.9 & 83.5 & 55.1 & & 74.7 \\
RBG 96 & 67.4 & 79.1 & 69.4 & 58.1 & 67.4 & 79.1 & 58.1 & & 81.4 \\
RBG 97 & 74.2 & 77.4 & 65.2 & 58.1 & 74.2 & 86.0 & 59.1 & & 82.8 \\
RBG 98 & 51.9 & 74.1 & 62.5 & 53.1 & 61.7 & 84.0 & 45.7 & & 76.3 \\
RBG 99 & 59.7 & 85.7 & 66.2 & 45.5 & 55.8 & 88.3 & 51.9 & & 80.5 \\
\hline SGB 94 & 67.1 & 70.7 & 74.4 & 59.3 & 72.0 & 82.9 & 58.5 & 82.7 & \\
SGB 95 & 58.2 & 74.0 & 74.7 & 54.4 & 68.4 & 88.6 & 48.7 & 74.7 & \\
SGB 96 & 60.5 & 77.9 & 67.1 & 53.5 & 65.1 & 76.7 & 52.3 & 81.4 & \\
SGB 97 & 73.1 & 76.3 & 75.0 & 57.0 & 78.5 & 83.9 & 61.3 & 82.8 & \\
SGB 98 & 56.3 & 70.0 & 68.4 & 50.0 & 60.0 & 78.8 & 50.0 & 76.3 & \\
SGB 99 & 66.2 & 76.6 & 72.7 & 53.2 & 59.7 & 81.8 & 50.6 & 80.5 & \\
\hline Average & 71.3 & 59.9 & 71.9 & 66.0 & 71.9 & 70.2 & 65.2 & 68.6 & 68.4 \\
\hline STD & 12.4 & 13.5 & 9.0 & 14.4 & 9.3 & 10.3 & 15.1 & 11.3 & 10.9 \\
\hline Diff. & 59.0 & 46.4 & 62.9 & 51.6 & 62.5 & 60.0 & 51.1 & 57.3 & 57.5 \\
\hline \hline
\end{tabular}

The average "frequency with which each" Justice "vote[s] together" with each of his or her colleagues "in full opinion decisions" measures that Justice's proximity to the Court's ideological center of gravity. ${ }^{153}$ All other things being equal, a high average suggests greater comfort with the Court's collective political preferences. By contrast, the standard deviation among any one Justice's rates of agreement with his or her colleagues reflects that Justice's propensity toward favoritism in building coalitions. "The higher the standard deviation, the more violent the disparity in an individual Justice's voting alignments with his or her colleagues"-and commensurately lower that Justice's ability to forge distinct alliances. ${ }^{154}$ We therefore treat the difference between the average and the standard deviation as a rough measure of collegiality.

153. Id. at 404 .

154. Dangerous Justice, supra note 1 , at 90. 
By this gauge, Justices O'Connor, Kennedy, and Souter fare quite well; all three register at or above sixty. Chief Justice Rehnquist follows closely in fourth place at 59.0. The three Justices most often regarded as occupying the ideological frontiers of the Court-Justices Scalia and Thomas on the right, and Justice Stevens on the left-fare relatively poorly. All three hover at or even discernibly below fifty. Justice Thomas's whopping 15.1 standard deviation is two-thirds higher than the 9.0 figure posted by Justice O'Connor, while Justice Stevens's average of 59.9 is less than the average minus standard deviation for Justices O'Connor, Kennedy, and Souter.

In short, the final "plus factor" favors the trio that wrote the joint opinion in Planned Parenthood of Southeastern Pennsylvania $v$. Casey. ${ }^{155}$ The Chief Justice follows closely enough to merit honorable mention.

\section{E. THERE HE IS: THE MOST DANGEROUS JUSTICE}

We believe we have a winner. Justices Kennedy and O'Connor dominate all three indirect measures of voting strength. Their frequent participation in the conservative bloc that has decided some of the most prominent and controversial cases of the past decade distinguishes them from Justice Souter. Chief Justice Rehnquist, for his part, did well enough to ratify his inclusion as a Power Pageant finalist. Unlike Justice Kennedy, however, Justice O'Connor performed poorly on our direct measures of voting power on the Court. Her robust performance on casual measures of strength cannot outweigh her failure to register bigger numbers in the formal tests. Justice O'Connor, after all, failed to qualify as a finalist at the conclusion of the Power Pageant's strictly quantitative phase. She was battling to distinguish herself from Justices Ginsburg, Breyer, and Thomas, not striving to dethrone Justices Kennedy and Souter. We therefore disqualify her from contention for the title of Most Dangerous Justice.

In that case, please pass the envelope. Associate Justice David $H$. Souter is our First Runner-Up, and William $H$. Rehnquist may now add Mr. Congeniality to his title as Chief Justice of the United States. The Most Dangerous Justice of the Clinton-Rehnquist Court is ...

\section{Associate Justice Anthony M. Kennedy}

155. 505 U.S. 833 (1992). 


\section{THE SUPPLE IN SPIRIT SHALL INHERIT THE KINGDOM OF POWER}

\section{A. MATHEMATICAL MOVEMENT AND MAYHEM IN THE MARKETPLACE OF SCHEMES}

\section{Divergence and Congruence}

Having named Justice Kennedy the winner of the Power Pageant of the Justices, we now move to a competition of utter political insignificance but substantial methodological interest. In the end, have we successfully deflected Professor Lynn Baker's criticisms? Have we whipped the competition in our little corner in the marketplace of schemes? And hardest of all: which of the six competing measures reviewed in this Article gives the most reliable answers to questions of power on the Supreme Court? Every developer of a mathematically informed model mutters sotto voce, "There are these recipes ... these equations that seem to rule the world." "We seek some assurance that we have moved closer toward grasping the mathematical underpinnings of the traffic in persuasive power within the Supreme Court.

Call it the Power Pageant of the Indexes. Unlike its counterpart at the highest court in the land, this pageant does not yield dividends in the guise of precedents and pronouncements. Rather, the winner of this Power Pageant will grab "the only coin" most scholars deem "worth having": the "applause" of our academic peers. ${ }^{157}$

We start with two assumptions. First, we assume that there really are differences in voting power among the Justices. Even Lynn Baker agrees that there is a Most Dangerous Justice and that his or her "identity ... matter[s]." "Second, we also assume that the distribution of power among the Justices remains reasonably stable over time. This assumption drives our search for more information on the Court's voting patterns and our preference for cumulative over Term-by-Term applica-

156. David BerlinskI, The Advent of the Algoritem: The IDEA That RULES THE WORLD 20 (2000).

157. Paul A. Samuelson, Economists and the History of Ideas, 52 AM. ECON. REV. 1, 18 (1962).

158. Baker, supra note 2, at 207. 
tions of our indexes. The Justices do appear to shift over time, but we presume that even ideological evolution and shifts in political savvy have their limits.

Combining our core assumptions yields two criteria for assessing measures of voting power on the Supreme Court. First, any index should reflect significant differences in power among the Justices. There is no validity in an index that converges at the benchmarks of an 11.1 power rating and a JQ of 100 for each Justice. In other words, a valid index should reflect some differences among the Justices, and those differences should be attributable to uneven degrees of power.

Second, once enough information has accumulated, a valid index should not vary substantially. Significant Term-to-Term instability in a mature index, as evidenced by wild swings in individual Justices' ratings, is as undesirable as complete convergence. Indeed, precision among competing measures of voting power-if not the accuracy of each individual gauge-can be computed through convergence among indexes. Indexes that report meaningful information should reach some sort of consensus. One must take care to distinguish the generally desirable phenomenon of convergence among indexes from convergence within a single index, which sounds the death knell for that index.

Of these criteria, the first is much easier to satisfy. In our study, every measure but one avoids the dreaded fate of dissolving into a pool of perfectly equal Justices, each wielding $11.1 \%$ of the Court's power. Attaining mathematical congruence among superficially meaningful indexes, however, may prove more difficult. If separate indexes do not begin to resemble each other over time, two explanations are possible. On one hand, at least one of the indexes may be invalid. On the other, each index may be valid in its own domain. The coalitional structure underlying the Supreme Court may be as complex as it is deep. Of itself, the fact that so many of these measures of voting power have yielded superficially plausible information suggests that different measures may simply measure different things. In that event, the failure of indexes to converge demands a more nuanced explanation of the dynamics underlying each index.

Finally, mindful of the roots of our 1996 articles, we prefer indexes that perform well both in the short run and in the long run. Of these time frames, the long run is easier to satisfy. As cases accumulate, a valid measure of power on the Supreme 
Court should neither dissolve into meaningless equality nor oscillate wildly. But the long run is a long time, and the Court rarely retains the same personnel for more than three or four years. The Most Dangerous Justice represented an elaborate effort to find short-term insights into the power dynamics among a potentially evanescent group of nine Justices. Once we identify a set of credible long-run gauges of power on the Court, we hope to find indexes that can reliably predict longrun trends with a single Term's worth of information.

\section{Infant Mortality}

Not every index described and deployed in this study will compete in the Power Pageant of the Indexes. Even before engaging in more rigorous tests of these indexes, we can partially or fully disqualify two of our indexes and two of Professor Baker's proposed measures of the median Justice. Our sophisticated index offers no value on a Term-by-Term basis. Its annual applications are routinely riddled with zeros and absurdly high power ratings. Whatever value lurks in the sophisticated index can be realized only in a long-run, cumulative application.

Our generalized Banzhaf index has the opposite problem. Though it might shed meaningful light on the Justices' performances each Term, it rapidly erodes as it accumulates information. To put it bluntly, the full-blown measure of feasibility developed in The Most Dangerous Justice flunks the test of time. We acknowledged in 1996 that we introduced the technique of inferring feasibility from the intersection of observed coalitions solely to solve the problem of small numbers. ${ }^{159}$ Now that we have a fuller set of data, the fancy mathematics are no longer necessary. Indeed, they affirmatively impair long-run assessment of the Power Pageant of the Justices. Inferred feasibility eventually overstates the number of feasible coalitions. By the end of the 2000 Term, our feasibility measure reported that 497 of 512 theoretically possible coalitions were politically feasible. This strikes us as extremely unlikely. After seven Terms, the number of distinct, actually observed majority coalitions reached only ninety-five, well short of the theoretical limit of 256. More than half of these ninety-five emerged in the first two Terms of our study. We believe that the Justices are approaching the political limits on their ability to cooperate.

159. See Dangerous Justice, supra note 1 , at 75,86 . 
Let us restate our conclusion more formally: As the number of actual cases increases, the artifice of inferring feasible coalitions decays in effectiveness. A sufficiently diverse array of actually observed coalitions will generate a constantly increasing set of unobserved but presumably feasible coalitions. As that number approaches 512 , the judicial quotient for all Justices will approach 100. At that point the algorithm for inferring feasibility can no longer be regarded as valid.

At most our generalized Banzhaf index remains useful as a short-run tool, when fuller information is unavailable. As we noted in Table 1 in Part II.A.4, the Justices have formed 209 unique coalitions out of a possible total of 512. As applied to the 1994 Term, the generalized Banzhaf index predicted a total of 308 coalitions. Applying the same methodology to the next Term (and only that Term) generated 228 coalitions. If, as we expect, the ceiling on the Justices' ability to cooperate is substantially lower than the theoretically upward limit of 512 coalitions but somewhat higher than the 209 coalitions observed to date, the generalized Banzhaf index may retain some value. We hasten to stress, however, that the generalized Banzhaf index becomes less reliable with the accrual of more information. In Part IV.C below, we will determine the precise extent to which the generalized Banzhaf index predicts long-run results under the naive and sophisticated indexes and the modified median measure.

Although we concede that the quest for a median Justice does not altogether lack merit, we also eliminate Lynn Baker's standard measure and decision method from further consideration. Both of Professor Baker's measures exhibit a trait that we consider deleterious: inclusion of multiple cases decided by the same coalition. Her standard measure in particular confers far too much weight to unanimous decisions. Nine-to-nothing is not only the most frequent margin of victory on the Court; it is also the margin that says the least about coalitional possibilities among the Justices.

The stark political tilt of Professor Baker's decision method exposes a second flaw. No other power index divides the Court into fractions separated not only by power but also by ideology. The decision method depicts a Court of five conservatives, exerting various levels of influence but all exceeding their expected power, and four uniformly impotent liberals. This implausible result derives from the large number of cases decided by a single five-Justice alliance-that of Chief Justice 
Rehnquist and Justices O'Connor, Scalia, Kennedy, and Thomas. The same defect lurks within Baker's standard measure but becomes dramatically more visible in the decision method, which lacks the dampening effect of other coalitions.

Whereas our generalized Banzhaf index has died a baroque death, excessive simplicity cripples Lynn Baker's response to our original proposal. The work of the Supreme Court transcends the unidimensional approach of the Shapley-Shubik index and Professor Baker's variation on that theme. Few "easy" cases reach the high court. ${ }^{160}$ The Court's recent tendency to splinter into smaller coalitions and to write a greater number of separate opinions suggests that the docket is growing increasingly complex. ${ }^{101}$ "It verges on the unsporting to name a ... Supreme Court controversy" that hinges on more than a single legal issue. ${ }^{162}$ At least one scholar speaks explicitly of distinct "legal" and "policy" dimensions along which Justices must negotiate in order to forge a single winning coalition. ${ }^{163}$ Professor Baker's rudimentary approach cannot overcome that single layer of additional complexity.

We nevertheless cannot categorically reject a measurement based on the assumption that there is a discernible median Justice. The modified median measure satisfies our two basic criteria: It neither converges toward the 11.1 power rating/100 JQ benchmark nor exhibits wild variations in its results. In methodological terms, it closely resembles Baker's standard measure. Both indexes count all coalitions, in contrast with our focus on five- and four-Justice coalitions. The modified median measure's principal advantage lies in its exclusion of multiple cases decided by the same coalition. That technique, which it shares with our naive and sophisticated indexes, spares the modified median measure of defects that afflict Baker's standard measure and decision method. The modified median measure suffers from neither the dilution attributable to multiple crediting of unanimous decisions nor the docket

160. See Saul Brenner \& Theodore S. Arrington, Unanimous Decision Making on the U.S. Supreme Court: Case Stimuli and Judicial Attitudes, 9 POL. BEHAV. 75, 83-84 (1987).

161. See Scott P. Johnson, The Influence of Case Complexity on the Opinion Writing of the Rehnquist Court, 25 OHI N.U. L. REV. 45, 58 (1999); see also Saul Brenner, Tony Caporale, \& Harold Winter, Fluidity and Coalition Sizes on the Supreme Court, 36 JURIMETRICS J. 245, 252-53 (1996) (suggesting institutional reasons that discourage Justices from coalescing around a losing legal position).

162. Sultans of Swing, supra note 3, at 231.

163. See Cross, supra note 15 , at 551. 
bias aggravated by the multiple crediting of five-Justice coalitions. It confirms the wisdom of counting the number of unique coalitions rather than the frequency with which they recur.

In short, though we reject the specific measures that Professor Baker proposed, we will give our chief critic the methodological benefit of the doubt. The modified median measure will advance in the Power Pageant of the Indexes, where it will sustain the possibility that a Supreme Court power index can be based on a search for the median Justice.

\section{Staying Alive}

Two measures out of six satisfy the initial demands of divergence from the $100 \mathrm{JQ}$ benchmark and congruence over time: our naive index and the modified median measure that we developed in response to Lynn Baker's criticisms of our original proposal. Our sophisticated index reports no usable results on a Term-by-Term basis, but it may provide valid information if calculated on a cumulative basis. Our generalized Banzhaf index is its mirror image. Over the long run, it dissolves completely into a pool of equal power ratings. Computed annually, however, it may predict the long-run results of the naive index, sophisticated index, or modified median measure.

We will stage a Power Pageant of the Indexes in two phases. First, we will compare three indexes to see whether their results converge over the long run. Second, mindful that the cohesion of the Court's personnel over seven Terms is historically rare, we will test a separate set of three indexes for their ability in the short run, on a Term-by-Term basis, to predict the Justices' long-run power ratings. The naive index, sophisticated index, and the modified median measure will compete in the long-run phase of this pageant. Term-by-Term applications of the naive index, generalized Banzhaf index, and the modified median measure will compete as alternative shortrun methods of predicting the three long-run measures.

Once again, let the games begin.

\section{B. THE POWER PageanT OF THE INDEXES}

\section{Madness in Our Methodology}

One mathematical tool looms large in this methodological Power Pageant. Root mean square error analysis provides a rough measurement of congruence between two indexes. Consider, for instance, a comparison of our naive and sophisticated 
indexes for October Term 1994. Our naive index reported that Chief Justice Rehnquist exerted $13.8 \%$ of the Court's voting power during the 1994 Term and that Justice O'Connor registered $10.7 \%$ on the same scale. According to the sophisticated index for the same time frame, the Chief Justice captured 13.3\% of the Court's power, while Justice O'Connor garnered $20.0 \%$. To compute the mean square error, we square the difference between the two indexes for each Justice and add those results. To wit:

$$
(0.138-0.133)^{2}+\ldots+(0.107-0.200)^{2}+\ldots
$$

We then take the square root of this sum. The smaller the result, the closer the indexes in question.

Root mean square error analysis is flexible enough to accommodate all combinations of short- and long-run results: annual results can be compared with annual results, cumulative results can be compared with cumulative results, and annual results can be compared with cumulative results. We will use it in two ways. First, to test congruence among indexes over the long run, we will compare running cumulative results of the naive index, sophisticated index, and the modified median measure after each Term. Second, to assess the ability of indexes to predict long-run results from a single Term's results, we will compare Term-by-Term results from the naive index, the generalized Banzhaf index, and the modified median measure with the cumulative results after October Term 2000 of the naive index, the sophisticated index, and the modified median measure.

\section{The Congruence Contest}

We first report two similar root mean square error analyses. Both analyses compare two indexes on a running cumulative basis. The second column in the following table compares the naive and sophisticated indexes; the third compares the modified median measure with the sophisticated index: 
Table 23: Root Mean Square Error Analysis, Running

Cumulative Results; Naive Index and Modified Median Measure Versus Sophisticated Index

\begin{tabular}{|c|c|c|}
\hline Term(s) & Naive v. sophisticated & $\begin{array}{c}\text { Modified median v. } \\
\text { sophisticated }\end{array}$ \\
\hline 1994 & 0.215 & 0.199 \\
\hline $1994-95$ & 0.159 & 0.171 \\
\hline $1994-96$ & 0.149 & 0.156 \\
\hline $1994-97$ & 0.070 & 0.070 \\
\hline $1994-98$ & 0.041 & 0.039 \\
\hline $1994-99$ & 0.066 & 0.066 \\
\hline $1994-2000$ & 0.088 & 0.085 \\
\hline
\end{tabular}

We have reported these indexes together because they report substantially, even strikingly, similar results. Both the naive index and the modified median measure begin as poor matches for the sophisticated index, registering root mean square errors near or above 0.200 . In the following four Terms, the accretion of additional cases decided by the Court consistently and dramatically reduced this error by a factor of five. At the end of the 1998 Term, a root mean square error of roughly 0.040 suggested that both the naive index and the modified median measure were much more congruent with the sophisticated index.

But the comparison reversed course over the 1999 and 2000 Terms. After both Terms, both the naive index and the modified median measure exhibited greater divergence from the sophisticated index. Taking the 1999 and 2000 Terms into account actually yields an increase rather than a decrease in the root mean square error. The final figures, 0.088 and 0.085 respectively, cast doubt on at least one of our assumptions.

Sudden divergence among competing indexes undermines the hypothesis that the Court's deep coalitional structure remains relatively stable over time. The instability in Table 23 can be attributed to the sophisticated index in general and to Justice Souter's swift rise in particular. Justice Souter's surge in our sophisticated index after the 1999 Term suggests either a radical shift in power or a flaw in our methodology. We would prefer to find concrete, convincing evidence of similar shifts in power from Term to Term, but neither our technique 
nor our data can resolve the problem conclusively. In fact, the cumulative results of our naive and sophisticated indexes differ considerably from the average of the results for individual Terms.

Volatility within coalitions can certainly alter the distribution of power on the Supreme Court. For example, Justice Kennedy's dissent in Stenberg $v$. Carhart ${ }^{164}$ suggests that his famous alliance with Justices O'Connor and Souter in Planned Parenthood of Southeastern Pennsylvania v. Casey ${ }^{165}$ may be collapsing. If so, we should abandon or at least modify our assumption that the distribution of power among Justices will remain stable. As we acknowledged in The Sultans of Swing, "[n]o one... would equate the Harry Blackmun of October Term 1971 with the Harry Blackmun of October Term 1993."166 The faster the Justices' views change, the stronger the preference for annual analysis of coalitional possibilities over cumulative data. A more nuanced approach would require us to isolate and discard coalitions rendered infeasible by changes in the Justices' ideologies over time. We have little confidence in the prospect of performing this task with any degree of accuracy.

On the other hand, if we isolate October Term 1999, our sophisticated index stabilizes a bit. Perhaps the 1999 Term was simply extraordinary. That Term alone certainly seems to account for much of the naive index and modified median measure's variation from the sophisticated indexes. Seven new five-Justice coalitions appeared that Term. ${ }^{167}$ Justice Souter

164. 530 U.S. 914, 956 (2000) (Kennedy, J., dissenting).

165. 505 U.S. 833 (1992).

166. Sultans of Swing, supra note 3, at 226. Compare, e.g., Furman v. Georgia, 408 U.S. 238, 411 (1972) (Blackmun, J., dissenting) ("We should not allow our personal preferences as to the wisdom of [the death penalty], or our distaste for [it], to guide our judicial decision in [capital] cases ....") with, e.g., Callins v. Collins, 510 U.S. 1141, 1145 (1994) (Blackmun, J., dissenting from denial of cert.) ("From this day forward, I shall no longer tinker with the machinery of death.").

167. See Sims v. Apfel, 530 U.S. 103 (2000) (Thomas, J., joined by Stevens, O'Connor, Souter \& Ginsburg, JJ.); Geier v. Am. Honda Motor Co., 529 U.S. 861 (2000) (Breyer, J., joined by Rehnquist, C.J., and O'Connor, Scalia \& Kennedy, JJ.); United States v. Playboy Entm't Group, Inc., 529 U.S. 803 (2000) (Kennedy, J., joined by Stevens, Souter, Thomas \& Ginsburg, JJ.); Christensen v. Harris County, 529 U.S. 576 (2000) (Thomas, J., joined by Rehnquist, C.J., and O'Connor, Kennedy \& Souter, JJ.); Carmell v. Texas, 529 U.S. 513 (2000) (Stevens, J., joined by Scalia, Souter, Thomas \& Breyer, JJ.); City of Erie v. Pap's A.M., 529 U.S. 277 (2000) (O'Connor, J., joined by Rehnquist, C.J., and Kennedy, Souter \& Breyer, JJ., as to Parts I and II); Shalala v. Ill. Council on 
participated in six of these; ${ }^{168}$ Justice Kennedy, in four. ${ }^{169}$ Even the Harvard Law Review, despite using more stringent criteria, recognized five new five-Justice coalitions during the 1999 Term. ${ }^{170}$ Indeed, during the previous Term, Justice Souter led a coalition combining his vote with those of Justices Stevens, Scalia, Thomas, and Ginsburg. ${ }^{171}$ On the other hand, Justice Souter's power grab was true to his reputation as the "Stealth Justice."172 Justice Souter wrote the majority opinion for none of the new five-Justice coalitions in the 1999 Term. Instead, he passively joined each of the winning coalitions.

For purposes of explaining Justice Souter's sudden surge in the sophisticated index, however, it is equally important to note the coalitions that failed to include Justice Souter. Out of six new four-Justice coalitions that first appeared during the 1999 Term, four excluded Justice Souter. The new five-Justice coalitions including Justice Souter magnified his raw power; the new four-Justice coalitions excluding Justice Souter enabled Justice Souter to abandon a corresponding number of fiveJustice majorities. Both phenomena sharply enhanced Justice Souter's showing in the sophisticated index.

Let us contemplate a less charitable explanation. Perhaps the sophisticated index is flawed insofar as it relies on a measure of feasibility. Recall that the sophisticated index is Banzhafs index of power to cast a dispositive vote, modified by a notion of feasibility that we derived strictly from observed coalitions. The potential weakness lies in our computation of feasibility over long stretches of time. In order to determine which members may feasibly defect from a five-Justice coalition that first emerges in the 1999 Term, we may reach as far back as the 1994 Term - the earliest Term in our data set-in order

Long Term Care, Inc., 529 U.S. 1 (2000) (Breyer, J., joined by Rehnquist, C.J., and O'Connor, Souter \& Ginsburg, JJ.).

168. To wit: Sims, Playboy, Christensen, Carmell, Erie, and Illinois Council.

169. To wit: Geier, Playboy, Christensen, and Erie.

170. See 1999 Harvard Survey, supra note 59, at 395 (identifying Geier, Illinois Council, Sims, Carmell, and Playboy).

171. See Jones v. United States, 526 U.S. 227 (1999); see also 1998 Harvard Survey, supra note 60, at 405.

172. See, e.g., David J. Garrow, Justice Souter Emerges: Once the Stealth Nominee, He Has Become an Intellectual Leader and the Supreme Court Has Become Politically Unpredictable, N.Y. TMES, Sept. 25, 1994, §6, at 36; Dick Lehr, A Step Toward the Left: Souter's Surprise Shift May Alter the Court, BOSTON GLOBE, July 1, 1993, at A11; Ruth Marcus, Souter Lessons Guide Thomas Game Plan, WASH. POST, Sept. 15, 1991, at A10. See generally Liang Kan, Comment, $A$ Theory of Justice Souter, 45 EMORY L.J. 1373 (1996). 
to discover as many as five subcoalitions of four Justices. What our model cannot determine is whether a four-Justice coalition observed in 1994 may in fact have become infeasible by 1999.

We shall offer a concrete example. The coalition consisting of Justices Stevens, Kennedy, Souter, Thomas, and Ginsburg appeared for the first time in the 1999 Term. Justice Kennedy wrote for this majority, over vigorous dissent, in United States $v$. Playboy Entertainment Group, Inc. ${ }^{173}$ Justice Souter received full credit for his participation in this coalition because our data set includes the subcoalition consisting of Justices Stevens, Kennedy, Thomas, and Ginsburg. That subcoalition, however, appeared during the 1995 Term in a fleeting portion of 44 Liquormart, Inc. $v$. Rhode Island. ${ }^{174}$ We have no way of knowing for certain whether those four Justices could feasibly agree on anything, to the exclusion of all the other Justices, during the 1999 Term. Four or five Terms can be jurisprudentially significant on a Court that rarely requires "a single human generation ... . to complete a constitutional hiccough."175

\section{Feasibility's Fate}

We must complete one more root mean square error analysis on a running cumulative basis. It compares the naive index with the modified median measure:

173. 529 U.S. 803 (2000) (Kennedy, J., joined by Stevens, Souter, Thomas \& Ginsburg, JJ.).

174. 517 U.S. 484, 508-14 (1996) (part IV of plurality opinion of Stevens, J.).

175. Jim Chen, DeFunis, Defunct, 16 CoNST. CoMmeNT. 91, 98 (1999). 
Table 24: Root Mean Square Error Analysis, Running

Cumulative Results; Naive Index Versus Modified Median Measure

\begin{tabular}{|c|c|}
\hline Term(s) & Root mean square error \\
\hline 1994 & 0.055 \\
\hline $1994-95$ & 0.051 \\
\hline $1994-96$ & 0.049 \\
\hline $1994-97$ & 0.042 \\
\hline $1994-98$ & 0.038 \\
\hline $1994-99$ & 0.035 \\
\hline $1994-2000$ & 0.030 \\
\hline
\end{tabular}

The naive index and the modified median index, the simplest measures in this study, actually exhibit congruence over time. These two indexes may be the only ones that exhibit concrete evidence of long-run coalitional stability. The relatively small root mean square error between these indexes continually decreases until it reaches a miniscule 0.030 after the 2000 Term.

These results suggest that the naive index and the modified median measure may become indistinguishable as Supreme Court decisions accumulate over multiple Terms. We will address that possibility in due course. The very fact that the naive index and the modified median measure are squaring off undermines the foundations of our sophisticated index and our generalized Banzhaf index. The development of those indexes constituted the bulk of our work in The Most Dangerous Justice and The Sultans of Swing. We will therefore first address this potentially subversive challenge to our methodology.

A simpler measure such as the naive index or the modified median measure may provide a more reliable long-run measure of voting power among Supreme Court Justices. The naive measure is less susceptible than its sophisticated counterpart to inevitable changes in individual Justices' points of view. A similar immunity to distortion over time is true of the modified median measure. Both of these measures omit the feasibility analysis that is the hallmark of the sophisticated and generalized Banzhaf indexes. To acknowledge this trait as a strength, 
however, rudely overthrows one of our basic assumptions. The naive index tacitly assumes that every member of a five-Justice coalition is capable of defecting. The modified median measure likewise ignores the fragility of provisional alliances that arise and collapse as the Justices forge decisive coalitions.

We developed the sophisticated index and the generalized Banzhaf index in response to two problems: (1) the size of the data set then available to us and (2) the inability to gauge whether every member of a winning coalition could have defected. Time, aided by the fortuity of stable Supreme Court membership across seven Terms, eliminated the problem of small numbers. In 1996 we recognized "that a larger number of cases decided by a single Court [might] obviate the need to rely on a mathematical surrogate for the Justices' coalition-building propensities."176 On this point, at least, we proved prophetic.

On the other hand, we may have overestimated the ideological limitations on a Justice's ability to defect. Feasibility may be a much weaker impediment than we imagined. It might not even exist. What we have learned about the Court's internal dynamics suggests that all coalitions may be logically feasible, though perhaps not equally likely to emerge in any given case or within any particular time frame.

If in fact feasibility is not as salient a concern as we originally assumed, must we also question our assumption "that the only time that an individual Justice's vote matters is when he is in a coalition of exactly five Justices"? ${ }^{177}$ This question holds the key to the contest between the naive index and the modified median measure. If we also abandon this assumption, which lies at the heart of John Banzhaf's measure of power, we might lose our basis for preferring the naive index over the broader modified median measure. Professor Baker could renew her critique that our focus on "decisions in which the winning coalition numbers precisely five Justices" comes at the expense "of ignoring as much as eighty percent of the available data."178

This line of criticism is not without force. Generally speaking, the smaller a losing coalition, the greater the likelihood that a nonprevailing Justice will change his or her vote. ${ }^{179}$ This

176. Sultans of Swing, supra note 3, at 225.

177. Dangerous Justice, supra note 1 , at 66.

178. Baker, supra note 2, at 202.

179. See Brenner et al., supra note 161, at 249-52; Saul Brenner \& Robert H. Dorff, The Attitudinal Model and Fluidity Voting on the United States Supreme Court: A Theoretical Perspective, 4 J. THEORETICAI POL. 195, 198-200 (1992); 
insight suggests that we might have erred in emphasizing the potential of a five-Justice coalition's pivotal member to defect. Perhaps we should have looked instead at the marginal propensity of a member in a losing four-Justice coalition to join the majority. Indeed, a four-Justice minority is less stable than a three-Justice minority. ${ }^{180}$ Except for the transformation of a 54 into a 6-3 decision, researchers interested "in exploring Supreme Court behavior... should focus on dissenters rather than on the majority."

Rehabilitation of our naive index, let alone assertion of its dominance over the modified median measure, depends on a defense of our focus on five-Justice coalitions. To that task we now turn.

\section{The Niftiness of Naïveté}

We believe that a focus on five-Justice coalitions fulfills certain important functions. The 5-4 decision retains its mystique and its importance. "On the Court, four is the loneliest number," because it takes five to fly. ${ }^{182}$ No less an authority than Learned Hand has asked, "Who in hell cares what anybody says about [constitutional law] but the Final Five of the august Nine ... ?"183 Five-to-four is the typical winning margin, ${ }^{184}$ or at least the second most typical (behind the unanimous Court). ${ }^{185}$ Why indeed does the Court seem to oscillate between unanimity and complete division? A 5-4 split provides far more information than a unanimous opinion on the Court's coalitional structures and propensities. Five-Justice coalitions arguably fight hardest to maintain or even to extend their margin of victory. ${ }^{186}$ Justices routinely dilute opinions to retain the

Robert H. Dorff \& Saul Brenner, Conformity Voting on the United States Supreme Court, 54 J. POL. 762, 768 (1993); Forrest Maltzman \& Paul J. Wahlbeck, Strategic Policy Considerations and Voting Fluidity on the Burger Court, 90 AM. POL. SCI. REV. 581, 587-89 (1996).

180. See Edelman \& Sherry, supra note 35 , at 1227, 1245-46.

181. Id. at 1227.

182. Sultans of Swing, supra note 3, at 233.

183. ALPHEUS T. MASON, HARLAN FISKE STONE: PILLAR OF THE LAW 384 (1956) (quoting correspondence from Judge Hand to then-Justice Stone).

184. WILITAM H. RIKER \& PETER C. ORDESHOOK, AN INTRODUCTION TO POSITIVE POLITICAL THEORY 177 (1973) (asserting that winning coalitions "will be no larger than they need to be").

185. See Edelman \& Sherry, supra note 35, at 1226 \& n.3 (ranking 5-4 decisions second in frequency behind unanimous decisions).

186. See EPSTEIN \& KNIGHT, supra note 9, at 66,74 . 
crucial fifth vote. ${ }^{187}$ Undoubtedly the truest Supreme Court maxim remains: "Five votes can do anything around here."

The loss of a fifth vote, of course, is fatal to a majority coalition. But even the failure to attract a sixth vote exposes a decision to a heightened probability of overruling by a later Court, reversal through congressional action, or lack of faithful implementation in the lower courts. ${ }^{189}$ All of these possibilities reinforce an oft-neglected truth: As a form of literature, Supreme Court opinions are not immune to the rhetorical and critical forces that shape the fate of all texts in the interpretive communities that receive them. ${ }^{190}$

The one-vote margin of a 5-4 decision delivers victory, but evidently with diminished persuasive force. The Justices themselves accord less respect to $5-4$ decisions. ${ }^{191}$ Congress appears more willing to throttle statutory decisions rendered by a narrow margin. ${ }^{192}$ Even more intriguingly, expanding a fiveJustice majority may forestall disrespect or outright defiance by the lower courts that are chiefly responsible for implementing nearly all of the Supreme Court's decisions, whether statutory or constitutional in nature. ${ }^{193}$ There is some evidence that

187. See, e.g., BERNARD SchWARTZ, DEcision: How THE SUPREME COURT DECIDES CASES 222 (1996) (describing how Justice Brennan diluted Baker v. Carr, 369 U.S. 186 (1962), in order to keep Justice Stewart as the winning coalition's fifth vote).

188. Id. at 6 (attributing this aphorism to Justice Brennan); JAMES F. SMON, THE CENTER HOLDS: THE POWER STRUGGLE INSIDE THE REHNQUIST COURT 54 (1995) (same).

189. See Edelman \& Sherry, supra note 35 , at $1244-45$ \& n.67.

190. See generally Robert A. Ferguson, The Judicial Opinion as Literary Genre, 2 YALE J.L. \& HUMAN. 201 (1990).

191. See, e.g., 44 Liquormart, Inc. v. Rhode Island, 517 U.S. 484, 510 (1996) (plurality opinion) ("Because the 5-to-4 decision in [Posadas de Puerto Rico Assocs. v. Tourism Co., 478 U.S. 328 (1986)] marked such a sharp break from our prior precedent, and because it concerned a constitutional question about which this Court is the final arbiter, we decline to give force to its highly deferential approach."); Nichols v. United States, 511 U.S. 738, 746 (1994) (suggesting that the "degree of confusion following a splintered" Supreme Court decision constitutes "a reason for reexamining that decision"); MURPHY, supra note 8, at 66; Cross, supra note 15, at 555-56.

192. See William N. Eskridge, Jr., Overriding Supreme Court Statutory Interpretation Decisions, 101 YALE L.J. 331, 346-47 (1991); Beth Henschen, Statutory Interpretations of the Supreme Court: Congressional Response, 11 AM. POL. Q. 441, 447 (1983); Thomas R. Marshall, Policymaking and the Modern Court: When Do Supreme Court Rulings Prevail?, 42 W. POL. Q. 493, 495 (1989).

193. See Cross, supra note 15, at 563; Edward Rubin \& Malcolm Feeley, Creating Legal Doctrine, 69 S. CAL. L. REv. 1989, 2018, 2031 (1996) (observing that reliance on lower courts for implementation forces the Supreme Court to 
lower courts give less credence to narrow or splintered Supreme Court decisions. ${ }^{194}$ At the very least, it appears easier to recite than to apply the rule that governs a "fragmented" decision in which "no single rationale explain[s] ... the assent of five Justices: 'the holding of the Court may be viewed as that position taken by those Members who concurred in the judgment] on the narrowest grounds." 195 That lower courts are formally bound to heed the Supreme Court's decisions ${ }^{196}$ does not foreclose idle speculation about violating the strict rule of vertical stare decisis. ${ }^{197}$

Let us consider the opposite possibility. Might our error lie in underestimating rather than overestimating the Justices' political instincts? We originally assumed that "the Justices vote

respect its own precedent to some degree); Emerson H. Tiller, Putting Politics into the Positive Theory of Federalism: A Comment on Bednar and Eskridge, 68 S. CAL. L. REV. 1493, 1499-1500 (1995) (hypothesizing that sound reasoning at the Supreme Court level raises costs for lower courts that might contemplate evasion of putatively binding precedent). See generally Lawrence Baum, Implementation of Judicial Decisions: An Organizational Analysis, 4 AM. POL. Q. 86 (1976). For critiques of the closely related phenomenon of plurality opinions, see John F. Davis \& William L. Reynolds, Juridical Cripples: Plurality Opinions in the Supreme Court, 1974 DUKE L.J. 59; Douglas J. Whaley, $A$ Suggestion for the Prevention of No-Clear-Majority Judicial Decisions, 46 TEX. L. REV. 370 (1968); Note, Plurality Decisions and Judicial Decisionmaking, 94 HARV. L. REV. 1127 (1981).

194. See, e.g., King v. Palmer, 950 F.2d 771, 781-83 (D.C. Cir. 1991) (en banc) (declaring a court of appeals' inability to decipher Pennsylvania v. Delaware Valley Citizens' Council for Clean Air, 483 U.S. 711 (1987), because of alleged inconsistencies between the plurality opinion and Justice O'Connor's concurrence in the judgment); Paper Converting Mach. Co. v. Magna-Graphics Corp., 745 F.2d 11, 17 (Fed. Cir. 1984) ("We must be cautious in extending five to four decisions by analogy ...."); United States v. Kennesaw Mountain Battlefield Ass'n, 99 F.2d 830, 833-34 (5th Cir. 1938) ("II]t is not controlling for the further reason, that that case, decided as it was by a closely divided court, is authority only for its own facts, and those facts are not present here."); $c$. Hopwood v. Texas, 78 F.3d 932, 945 (5th Cir.) (refusing to accord deference to "Justice Powell's lonely opinion" in Regents of the University of California $v$. Bakke, 438 U.S. 265 (1978)).

195. Marks v. United States, 430 U.S. 188, 193 (1977) (quoting Gregg v. Georgia, 428 U.S. 153, 169 n.15 (1976)). See generally Maxwell L. Stearns, The Case for Including Marks v. United States in the Canon of Constitutional Law, 17 CONST. COMMENT. 321 (2000).

196. See Agostini v. Felton, 521 U.S. 203, 235-36 (1997); Am. Trucking Ass'ns, Inc. v. Smith, 496 U.S. 167, 180 (1990) (plurality opinion); Rodriguez de Quijas v. Shearson/Am. Express, Inc., 490 U.S. 477, 484 (1989); Hutto v. Davis, 454 U.S. 370, 374-75 (1982) (per curiam).

197. See Michael Stokes Paulsen, Abrogating Stare Decisis by Statute: May Congress Remove the Precedential Effect of Roe and Casey?, 109 YALE L.J. 1535, 1538 n.8, 1597 n.169 (2000). 
strictly to legal principle and do not trade votes as though they were so many horses at a swap meet."198 "This assumption is thoroughly grounded in legal convention. "[C]ynical strategizing by the Court seems the very essence of democratic betrayal." 199 American legal culture upholds a strong separation of judicial craftsmanship from politics. ${ }^{200}$ More than four decades after Herbert Wechsler advocated a "genuinely principled" judicial process grounded in "analysis and reasons quite transcending the immediate result that is achieved," 201 "the concept of neutral principles remains an article of faith." "202 True to this creed, explicit "logrolling seldom if ever occurs on the Court."203 Efforts to expose outright vote-swapping have unearthed no evidence. ${ }^{204}$ Surprising though it may seem, "some judges feel an obligation to do the job right." 205

On the other hand, less overt forms of judicial cooperation do exist. In a less charitable mood, we might call them "soft logrolling."206 At a minimum, judges follow a well established "norm" of "sacrific[ing] details of their convictions in the service of producing an outcome and opinion attributable to the

198. Dangerous Justice, supra note 1, at 73.

199. Book Note, Democracy and Dishonesty, 106 HARv. L. REv. 792, 794 (1993) (reviewing JOSEPH GOLDSTEIN, THE INTELLIGIBLE CONSTTIUTION: THE SUPREME COURT'S OBLIGATION TO MAINTAIN THE CONSTITUTTON AS SOMETHING WE THE PEOPLE CAN UNDERSTAND (1992)).

200. See, e.g., cases cited supra note 5; Rubin \& Feeley, supra note 193, at 2026 (arguing that judges take seriously "institutionally induced beliefs about the way they should carry out their official functions"); Kathleen M. Sullivan, The Supreme Court, 1991 Term-Foreword: The Justices of Rules and Standards, 106 HARV. L. REV. 22, 120 (1992) ("Most judges hold deeply internalized role constraints and believe that judgment is not politics.").

201. Herbert Wechsler, The Supreme Court, 1958 Term-Foreword: Toward Neutral Principles of Constitutional Law, 73 HARV. L. REV. 1, 15 (1959).

202. Susan Bandes, Book Note, Erie and the History of the One True Federalism, 110 YALE L.J. 829, 832 (2001) (reviewing EDWARD A. PURCELL, JR., BRANDEIS AND THE PROGRESSIVE CONSTTTUTION: ERIE, THE JUDICIAI POWER, AND THE POLITICS OF THE FEDERAL COURTS IN TWENTIETH-CENTURY AMERICA (2000)).

203. Cross, supra note 15 , at 566.

204. See Robert A. CARP \& RONALD STtmham, THE Federal CourTs 160 (2d ed. 1991); Mark Tushnet, Themes in Warren Court Biographies, 70 N.Y.U. L. REV. 748, 764 n.86 (1995).

205. Thomas O. McGarity, On Making Judges Do the Right Thing, 44 DuKE L.J. 1104, 1105 (1995).

206. See Cross, supra note 15, at 566-67; Frank B. Cross \& Emerson H. Tiller, Judicial Partisanship and Obedience to Legal Doctrine: Whistleblowing on the Federal Courts of Appeals, 107 YALE L.J. 2155, 2175 (1998). 
court."207 Justice Stevens famously concurred in a "judgment vacating and remanding for further proceedings," contrary to his own "view that [the Court] should [have] affirm[ed] the judgment," because a "vote to affirm" would have meant that "no disposition of [the] appeal would [have] command[ed] the support of a majority of the Court.,"208

More active forms of persuasion abound. Chief among them is dissent. ${ }^{209}$ Dissent "safeguards the integrity of the judicial decision-making process by keeping the majority accountable for the rationale and consequences of its decision."210 Prominent "often in shaping and sometimes in altering the course of the law," 211 dissenting opinions uphold "the democratic faith."12 Every dissent, after all, is merely "an appeal to the brooding spirit of the law, to the intelligence of a future day, when a later decision may possibly correct the error into which ... the court [has ostensibly] been betrayed."213 Particularly persuasive draft dissents instantly become opinions for the Court; one study found that draft dissents affected a quarter of putatively "landmark" cases and a tenth of all cases decided within a single Supreme Court Term. ${ }^{214}$

The effect over time can be even more dramatic. The "Court record" that William $\mathrm{H}$. Rehnquist may have set by fil-

207. Lewis A. Kornhauser \& Lawrence G. Sager, The One and the Many: Adjudication in Collegial Courts, 81 CAL. L. REv. 1, 52-53 (1993).

208. Turner Broad. Sys., Inc. v. FCC, 512 U.S. 622, 674 (1994) (Stevens, J., concurring in part and concurring in the judgment).

209. See generally Post, supra note 58, at 1340-55 (tracing changes in Supreme Court Justices' attitudes toward dissent from the Taft era to the end of the 1940s); Kevin M. Stack, Note, The Practice of Dissent in the Supreme Court, 105 YALE L.J. 2235, 2246-58 (1996) (arguing that the practice of dissent reveals the deliberative character of a court's decisionmaking process and is therefore a source of judicial legitimacy).

210. William J. Brennan, Jr., In Defense of Dissents, 37 HASTINGS L.J. 427, 430 (1986); cf. Antonin Scalia, The Dissenting Opinion, 1994 J. SuP. CT. HIST. 33,41 (suggesting that the chronic absence of dissent would lead a judge "to suspect that his colleagues considered him insipid, or simply not worthy of contradiction").

211. Harlan F. Stone, Dissenting Opinions Are Not Without Value, 26 JUDICATURE 78, 78 (1942).

212. William O. Douglas, The Dissent: A Safeguard of Democracy, 32 JUDICATURE 104, 105 (1948) (praising "the uncertainty of the law" as a source of democratic "strength and glory").

213. ChaRles EvaNS HUgheS, THE SUPREME COURT OF THE UNITED STATES 68 (1928).

214. See EPSTEIN \& KNIGHT, supra note 9, at 77-78 (surveying the authors' own list of "landmark" cases and October Term 1983 in its entirety). 
ing fifty-four solo dissents as an Associate Justice ${ }^{215}$ arguably paved the way for the conservative landmarks established under his leadership. Then-Justice Rehnquist endured long enough to fulfill his "confident" prophecy in dissent that a robust view of federalism would "in time again command the support of a majority of [the] Court."216 Then again, the transformation of a heroic dissent into a future majority opinion may more properly belong to the realm of legend. Most dissenters tend to be holdovers from an eclipsed majority rather than heralds of a future coalition. ${ }^{217}$ In reprising the role of "the gladiator making a last stand against the lions," the dissenter is no more likely to taste success than his or her Roman predecessor. $^{218}$ As then-Justice Rehnquist pointedly observed, "comments in [a] dissenting opinion ... are just that: comments in a dissenting opinion." 219

Politics at the Supreme Court ultimately eludes analysis simply because it eludes detection. More than two-thirds of all Supreme Court cases involve some form of intramural bargaining through memoranda circulated to the entire Conference of the Justices. ${ }^{220}$ Such information comes to light, if ever, only through the release of a deceased Justice's records. ${ }^{221}$ There is

215. See BERnaRd Schwartz, THE ASCent OF PRAgMatism 29, 31-32 (1990); Laura K. Ray, A Law Clerk and His Justice: What William Rehnquist Did Not Learn from Robert Jackson, 29 IND. L. REV. 535, 586 n.316 (1996).

216. Garcia v. San Antonio Metro. Transit Auth., 469 U.S. 528, 580 (1985) (Rehnquist, J., dissenting); see also William Blodgett, Just You Wait, Harry Blackmun, 3 CONST. COMMENT. 3 (1986) (setting to music then-Justice Rehnquist's retort to Justice Blackmun's majority opinion in Garcia); cf., e.g., Printz v. United States, 521 U.S. 898 (1997); Seminole Tribe v. Florida, 517 U.S. 44 (1996); New York v. United States, 505 U.S. 144 (1992); Gregory v. Ashcroft, 501 U.S. 452 (1991).

217. See John Schmidhauser, Stare Decisis, Dissent, and the Background of the Justices of the Supreme Court of the United States, 14 U. TORONTO L.J. 196 (1962).

218. BENJANIN CARDOZO, LAW AND Literature 34 (1931); accord Bd. of Educ. of Kiryas Joel Vill. Sch. Dist. v. Grumet, 512 U.S. 687, 708 (1994) (describing a dissent by Justice Scalia as "certainly the work of a gladiator," even though "he thrusts at lions of his own imagining").

219. United States R.R. Ret. Bd. v. Fritz, 449 U.S. 166, 176 n.10 (1980).

220. See EPSTEIN \& KNIGHT, supra note 9, at 74 tbl.3-2 (reporting a rate of $70 \%$ for the landmark cases of the 1970s and 1980s).

221. Justice Marshall's papers are probably the most (in)famous of such sources. See generally, e.g., BERNARD SCHWARTZ, THE UNPUBLISHED OPINIONS OF THE REHNQUIST COURT (1996); James A. Thomson, Inside the Supreme Court: A Sanctum Sanctorum?, 66 Miss. L.J. 177 (1996); Mark V. Tushnet, The Supreme Court and Race Discrimination, 1967-1991: The View from the Marshall Papers, 36 WM. \& MARY L. REv. 473 (1995). 
no way to track the bargaining that occurs through private memoranda and oral communication.

As one of several plausible long-run gauges of Supreme Court voting power, the naive index does boast some intuitively attractive results. Minor fluctuations aside, the naive index, the sophisticated index, and the modified median measure all place Justice Kennedy, Justice Souter, and Chief Justice Rehnquist atop the Court. The bottom of each index reflects greater variation. Justices Stevens and Ginsburg finish at the bottom of the sophisticated index, while Justices Scalia, Thomas, and O'Connor bring up the rear according to the naive index. The modified median measure blends these assessments: It clusters Justices Scalia, O'Connor, Thomas, and Stevens in a virtual four-way tie for last place. Legal observers may disagree over whether the relatively liberal or the relatively conservative wing of the Court wields less influence, but we side with those who regard Justices Scalia and Thomas as more ideologically rigid and therefore less capable of forming coalitions.

Although we can generally assume that Justices, like all other judges, "like to win (or to be perceived as 'winners'),"222 it is almost certain that some Justices prefer victory more than others and are willing to accommodate their colleagues on finer legal points in order to magnify their voting power. (If nothing else, a Justice can enjoy the "vanity value [of] authoring a $m a-$ jority opinion." $)^{223}$ Justice Kennedy allegedly has adopted a "deliberate strategy" of "[o]ccupying the pivot" on today's Court. $^{224}$ By contrast, we have an admittedly untested and perhaps untestable hunch that Justices Scalia and Thomas prefer scoring ideological points and may even be willing to sacrifice an occasional imperfect victory in order to do so.

Several areas of the Supreme Court's jurisprudence indirectly support this conjecture. Justices Scalia and Thomas have routinely followed their own drummer in dormant commerce clause cases. ${ }^{225}$ Even more dramatically, both have

222. Tracey E. George, Developing a Positive Theory of Decisionmaking on U.S. Courts of Appeals, 58 OHIO ST. L.J. 1635, 1661 (1998).

223. Cross, supra note 15 , at 550 (emphasis added).

224. EDWARD LAZARUS, CLOSED CHAMBERS 515 (1998).

225. See, e.g., Camps Newfound/Owatonna, Inc. v. Town of Harrison, 520 U.S. 564, 595 (1997) (Scalia, J., dissenting); id. at 609 (Thomas, J., dissenting); W. Lynn Creamery v. Healy, 512 U.S. 186, 207 (1994) (Scalia, J., joined by Thomas, J., concurring in the judgment); Am. Trucking Ass'ns v. Smith, 496 U.S. 167, 202-05 (1990) (Scalia, J., concurring in the judgment); cf. Jim Chen, 
shown a propensity to write separately in statutory interpretation cases solely to criticize the rest of the Court's use of legislative history. ${ }^{226}$ (We leave for another time, and probably for other scholars, the striking incongruity between this position and Justice Scalia's chef d'ceuvre, Originalism: The Lesser Evil.) ${ }^{227}$ Then again, Justice Thomas may be softening his refusal to consider legislative history in statutory cases. During the 1997 Term, Justice Scalia withheld his vote from the portion of an opinion by Justice Thomas that discussed legislative history ${ }^{228}$ - and thereby deprived Justice Thomas of a Court for that footnote. ${ }^{229}$ Perhaps not coincidentally, that Term marked the beginning of Justice Thomas's gradual rise out of the Court's power trough. In "demonstrat[ing] that he [is] more than simply Justice Scalia's loyal apprentice,"230 Justice Thomas is also leaving the Court's unenviable basement to Justice Scalia.

In dissenting or concurring solely in the judgment of the Court, Justice Scalia almost assuredly seeks to "cancel[ the impact of monolithic solidarity on which the authority of this colleagues] so largely depends."231 Justice Scalia knows firsthand the negative consequences of failing to secure at least five

The Mystery and the Mastery of the Judicial Power, 59 MO. L. REv. 281, 302-05 (1994) (analyzing Justice Scalia's mysterious preference for making jurisprudential points over winning cases, at least when the dormant commerce clause is at stake).

226. See, e.g., Crosby v. Nat. Foreign Trade Council, 530 U.S. 363, 388-91 (2000) (Scalia, J., joined by Thomas, J., concurring in the judgment); Conroy v. Aniskoff, 507 U.S. 511, 512 n.† (1993) (noting Justice Thomas's refusal to join in a footnote that discussed legislative history, see id. at $518 \mathrm{n} .12$ ); id. at 518 (Scalia, J., concurring in the judgment); Wis. Pub. Intervenor v. Mortier, 501 U.S. 597, 616-23 (1991) (Scalia, J., concurring in the judgment); Chisom v. Roemer, 501 U.S. 380, 404-05 (1991) (Scalia, J., dissenting).

227. Antonin Scalia, Originalism: The Lesser Evil, 57 U. CIN. L. REV. 849 (1989).

228. See Nat. Credit Union Admin. v. First Nat'l Bank \& Trust Co., 522 U.S. 479,493 n.6 (1998).

229. See id. at 482 n.:

230. SCOTT DOUGLAS GERBER, FIRST PRINCIPLES: THE JURISPRUDENCE OF ClLARENCE THOMIAS 139 (1999).

231. LEARNED HAND, THE BILL OF RIGHTS 72 (1958); see also Pollock v. Farmers' Loan \& Trust Co., 157 U.S. 429, 608 (1895) (White, J., dissenting) ("The only purpose which an elaborate dissent can accomplish, if any, is to weaken the effect of the opinion of the majority, and thus engender want of confidence in the conclusions of courts of last resort."), overruled by South Carolina v. Baker, 485 U.S. 505 (1988); $c f$. N. Sec. Co. v. United States, 193 U.S. 197, 400 (1904) (Holmes, J., dissenting) ("חt is useless and undesirable, as a rule, to express dissent...."). 
votes for every jot, tittle, and footnote of a landmark opinion. ${ }^{232}$ It is Justice Scalia, after all, who has accused his colleagues of occupying an altogether alien planet: "The Court must be living in another world. Day by day, case by case, it is busy designing a Constitution for a country I do not recognize." ${ }^{\prime 233}$ To Justice Scalia, it has become a Court that cannot distinguish "a Kulturkampf [from] a fit of spite,"234 a Court that casually "sweeps aside [its] precedents ... and ignores the history of our people" in pursuit of what it considers "the desired result."235 In what he calls an "optimistic" mood, Justice Scalia has predicted that one of this Court's decisions eventually "will be assigned its rightful place ... beside Korematsu and Dred Scott."236 Justice Thomas may sympathize with such sentiments, but he rarely if ever expresses them in such bitter terms. Therein lies the difference between a Justice who has yet to achieve his expected share of the Court's power and a Justice who has forsworn in its entirety the quest for power.

In the crucial struggle between the naive index and the modified median measure, one final quantitative measure tips the balance in favor of the naive index. Recall our initial fear that our measures might dissolve over time into a soup of perfectly equal Justices. To test the propensity of the naive index and the modified median measure to succumb to the fate that swallowed our generalized Banzhaf index, we can determine each index's root mean square error vis-à-vis the dreaded "constant index" of 11.1 power ratings and $100 \mathrm{JQs}$ across the board. In this contest, the object is to register a relative high root mean square error.

232. Compare Michael H. v. Gerald D., 491 U.S. 110, 127-28 n.6 (1989) (plurality opinion of Scalia, J.) (directing substantive due process analysis to focus on the most specific level at which a novel liberty interest can be defended on the historical record), with id. at 132 (O'Connor, J., joined by Kennedy, J., concurring in part) (declining to endorse footnote six of Justice Scalia's opinion, which was in all other respects for the Court), and Planned Parenthood, Inc. v. Casey, 505 U.S. 833, 847 (1992) (rejecting the approach outlined in footnote six of Michael $H$. as "inconsistent with our law").

233. Bd. of County Comm'rs v. Umbehr, 518 U.S. 668, 711 (1996) (Scalia, J., dissenting).

234. Romer v. Evans, 517 U.S. 620, 636 (1996) (Scalia, J., dissenting).

235. United States v. Virginia, 518 U.S. 515, 566 (1996) (Scalia, J., dissenting).

236. Stenberg v. Carhart, 530 U.S. 914, 953 (2000) (Scalia, J., dissenting). 
Table 25: Root Mean Square Error Analysis Vis-À-Vis the Constant Index, Naive Index, and Modified Median Measure,

Running Cumulative Results

\begin{tabular}{||l|c|c||}
\hline Term(s) & Naive index & Modified median measure \\
\hline 1994 & 0.106 & 0.056 \\
\hline $1994-95$ & 0.087 & 0.042 \\
\hline $1994-96$ & 0.077 & 0.040 \\
\hline $1994-97$ & 0.066 & 0.034 \\
\hline $1994-98$ & 0.057 & 0.024 \\
\hline $1994-99$ & 0.055 & 0.025 \\
\hline $1994-2000$ & 0.049 & 0.023 \\
\hline Average & 0.071 & 0.035 \\
\hline
\end{tabular}

All other things being equal, greater distance from the constant index is better. Though regression toward the mean has afflicted both the naive index and the modified median measure over time, the naive index reports greater variation from the constant index and therefore greater distinctions in power among the Justices. Its final root mean square error reading is close to the modified median measure's initial reading. Throughout all seven Terms, the naive index consistently doubles the modified median measure's distance from the constant benchmark. The averages for the two root mean square error analyses confirm this trend. Since the naive index and the modified median measure are almost equally easy to compute, we believe that the index that reports greater variation in power is marginally more credible. Edge to the naive index.

We hasten to add one caveat. The sophisticated index performs even better relative to the constant index. The root mean square error analysis for the sophisticated index reports a final figure of 0.099 and a seven-Term average of 0.132. Both figures represent roughly the same degree of advantage vis-à-vis the naive index as the naive index enjoys relative to the modified median measure. This concededly crude quantitative measure, however, does not completely negate our doubts about the sophisticated index. We therefore stick to our basic assessment: In the long run, it's nifty to be naive. 


\section{The Message IN THE MEDIAN}

Few collections of Supreme Court Justices, however, ever reach the long run. Historically speaking, death, old age, and boredom take their toll every other year or so. It therefore behooves any chronicler of voting power on the Supreme Court to fashion an index that reliably predicts long-run trends on the basis of a single Term.

Three different long-run measures, we believe, reflect different aspects of Supreme Court voting power. We have touted the naive index as the simplest, most reliable measure of power among the Justices over the long run. By the same token, we are not prepared to discard the modified median measure. The case for preferring the naive index rests more heavily on rhetorical arguments than on quantitative evidence. Though we have declined the invitation to equate the Most Dangerous Justice with the median Justice, the notion of a median will retain its appeal as long as there are analysts who array the Justices along a single political dimension. Finally, despite our doubts about feasibility, the sophisticated index remains the lone measure that explicitly assesses whether a Justice can credibly threaten to abandon a coalition. Feasibility may be a phantom, but it would be formidable if it ever materializes. We will therefore try to find short-run surrogates for all three of these long-run measures.

In the analysis that follows, we will use root mean square error analysis to track the power of three short-run measuresthe naive index, the generalized Banzhaf index, and the modified median measure-to predict the long-run outcomes of the naive index, the sophisticated index, and the modified median measure. We will compare the single Term results for each of the short-run measures from October Term 1994 through October Term 2000 with the cumulative results of the long-run measures after the 2000 Term. The smaller the root mean square error, the closer the match between the indexes in question.

\section{Predicting the Cumulative Naive Index}

We begin by trying to emulate the long-run, cumulative results of our naive index through the Term-by-Term results of three different indexes: the naive index itself, the generalized Banzhaf index, and the modified median measure. 
Table 26: Predicting the Cumulative Naive Index; Term-byTerm Results-Naive, Generalized Banzhaf, Modified Median

\begin{tabular}{||l|c|c|c||}
\hline Term & Naive & Generalized Banzhaf & Modified median \\
\hline 1994 & 0.073 & 0.055 & 0.037 \\
\hline 1995 & 0.083 & 0.073 & 0.048 \\
\hline 1996 & 0.066 & 0.085 & 0.026 \\
\hline 1997 & 0.059 & 0.070 & 0.030 \\
\hline 1998 & 0.056 & 0.052 & 0.057 \\
\hline 1999 & 0.068 & 0.094 & 0.058 \\
\hline 2000 & 0.068 & 0.077 & 0.039 \\
\hline Average & 0.066 & 0.072 & 0.042 \\
\hline
\end{tabular}

Perhaps surprisingly, the Term-by-Term version of the naive index does not provide the best projection of the cumulative naive index. In every Term, the modified median measure performs best in predicting the naive index over the long run. The generalized Banzhaf index comes very close to matching the naive index. The 1999 Term, which cast a cloud on the very notion of feasibility, reappears in this table as the generalized Banzhaf index's worst Term.

2. Predicting the Cumulative Sophisticated Index

We now turn to the sophisticated index. As the following table shows, the sophisticated index is the long-run measure that is hardest to predict: 
Table 27: Predicting the Cumulative Sophisticated Index; Term-by-Term Results-Naive, Generalized Banzhaf, Modified Median

\begin{tabular}{||l|c|c|c||}
\hline Term & Naive & Generalized Banzhaf & Modified median \\
\hline 1994 & 0.133 & 0.104 & 0.098 \\
\hline 1995 & 0.098 & 0.099 & 0.081 \\
\hline 1996 & 0.119 & 0.106 & 0.081 \\
\hline 1997 & 0.132 & 0.111 & 0.091 \\
\hline 1998 & 0.111 & 0.094 & 0.099 \\
\hline 1999 & 0.080 & 0.113 & 0.087 \\
\hline 2000 & 0.087 & 0.106 & 0.070 \\
\hline Average & 0.109 & 0.105 & 0.087 \\
\hline
\end{tabular}

Because the two indexes share a feasibility measure, we expected the generalized Banzhaf index to provide the most accurate projection of the cumulative sophisticated index. It does not. It outperforms only the naive index, and by a very narrow margin at that. The modified median measure again prevails as the best predictor of a long-run index.

To be sure, none of the short-run measures performs especially well when lined up against the cumulative sophisticated index. All three short-run measures generate larger root mean square errors vis-à-vis the cumulative sophisticated index than they do relative to either of the other long-run measures. Feasibility therefore proves difficult across the board: elusive to measure in the long run with the sophisticated index, and elusive to predict using short-run data from the generalized Banzhaf index.

3. Predicting the Cumulative Modified Median Measure

To complete the picture, we turn finally to projections of the modified median measure: 
Table 28: Predicting the Cumulative Modified Median Measure; Term-by-Term Results-Naive, Generalized Banzhaf, Modified Median

\begin{tabular}{||l|c|c|c||}
\hline \hline Term & Naive & Generalized Banzhaf & Modified median \\
\hline 1994 & 0.090 & 0.045 & 0.040 \\
\hline 1995 & 0.077 & 0.054 & 0.037 \\
\hline 1996 & 0.090 & 0.070 & 0.025 \\
\hline 1997 & 0.073 & 0.076 & 0.041 \\
\hline 1998 & 0.045 & 0.034 & 0.031 \\
\hline 1999 & 0.061 & 0.079 & 0.043 \\
\hline 2000 & 0.051 & 0.057 & 0.024 \\
\hline Average & 0.070 & 0.059 & 0.034 \\
\hline \hline
\end{tabular}

The modified median measure wins this final encounter. With that victory, it sweeps all three contests to provide shortrun, single-Term surrogates for long-run information on voting power among the Justices. The struggle for second place also ends in interesting fashion. Paradoxically, the generalized Banzhaf index, in spite of its greater complexity, outperforms the naive index in predicting the modified median measure over the long run. Again, the generalized Banzhaf index faltered in the notorious 1999 Term. But it outperforms or rivals the naive index in every other Term.

On the whole, the generalized Banzhaf index performs reasonably well as a single-Term surrogate for cumulative data. It nips the naive index in this regard. In light of the modified median measure's sweep of all three contests, however, there appears to be no circumstance in which we would prefer the generalized Banzhaf index to project Supreme Court voting power over the long run. The generalized Banzhaf index therefore offers neither of the advantages that would commend its continued use: accuracy and simplicity. On this point we will graciously concede our chief critic's objections to our "elaborate mathematics."237 We bid farewell to the generalized Banzhaf index as a measure of Supreme Court voting power, in the short run as well as the long run. Bitter is the scholar's sad re-

237. Baker, supra note 2, at 190. 
frain, "Write today, regret tomorrow, renounce mañana."238

\section{THE PERMANENCE OF THE POWER PAGEANT}

To our original mission, we have remained faithful. To the fullest of our ability, we have brought mathematics to bear on the question of relative voting power among the Justices of the Supreme Court. Some uses of mathematics "to give a firm foundation for ... research" in disciplines outside the traditional sciences have "led to some real insight," while others have "produced, at best, a veneer of respectability."239 "There is something fascinating about science. One gets such wholesale returns of conjecture out of such a trifling investment of fact."240 We have been forced, alas, to couple the limited insights that mathematics can provide with a heavy dose of intuition.

Although we have been forced to abandon our generalized Banzhaf index and to temper our enthusiasm for our sophisticated index, our naive index triumphs as the best long-run gauge of Supreme Court voting power. The sophisticated index, computed cumulatively over a course of several Terms, remains the only measure that accounts for feasibility, our shorthand for political limits on the Justices' ability to form coalitions. Though we remain skeptical of the existence of a median Justice, we do embrace the modified median measure as the best way to predict voting power among the Justices over the long run with information from a single Term. It may be fairest to say that the three surviving measures-the naive index, the sophisticated index, and the modified median measure-simply reflect three different aspects of voting power among Supreme Court Justices. That phenomenon is evidently more complex than we originally anticipated, and we make no apologies for reaching correspondingly complex conclusions.

Most of all, we believe we have vindicated our application of game theory to the Court. To adopt less accurate gauges of Supreme Court voting power would strip the Power Pageant of the Justices of all mathematical meaning and reduce the search

238. Jim Chen, The Magnificent Seven: American Telephony's Deregulatory Shootout, 50 HASTINGS L.J. 1503, 1580 (1999).

239. Paul H. Edelman, A Tour of Mistakes, 93 Nw. U. L. REv. 343, 345 (1998).

240. MARK TWAIN, LIFE ON THE MISSISSIPPI 109 (Harper \& Row 1965); accord Whitcomb v. Chavis, 403 U.S. 124, 169 n.5 (1971) (separate opinion of Harlan, J.). 
for the Most Dangerous Justice to a mere "parlor game."241 Even our most ardent critic agrees that "[f]or those litigating before the Court, and even for the Justices themselves," it matters whether legal analysts have "conduct[ed] the proper Pageant."242 We hope that Professor Baker will also agree that our renewed look at the Power Pageant has settled the most important methodological questions.

There remain diehards who believe that the Court can be purged of its partisan stench. "When the Court no longer ultimately determines the great controversies of the day," so the faithful believe, "the other actors in the political system will not place so much importance on controlling the selection of the Justices." ${ }^{243}$ For the foreseeable future, though, the Court will continue to exert "pervasive influence on a wide range of issues that can only in a partial and peripheral way be considered legal rather than political."244 Until further notice, the Power Pageant of the Justices will matter.

True to the religious maxim that "the last shall be first, and the first last,"245 we shall give the last word to the jurist who placed dead last in the Power Pageant of the Justices. ${ }^{246}$ The Supreme Court, an institution designed to be a step removed from the maelstrom of partisan politics, yields its secrets only to those Justices who are willing and able to seize the

241. See Dangerous Justice, supra note 1 , at 68 n.25 (proposing a parlor game as an indirect illustration of the distinction between feasible and infeasible coalitions of Justices). Compare Sultans of Swing, supra note 3, at 228 ("The power pageant of the Justices would be a frivolous parlor game for Supreme Court watchers, and no more."), with Baker, supra note 2, at 207 ("Is the Power Pageant just a parlor game? ... Do Power Pageants of the Court offer anything more than entertainment?").

242. Baker, supra note 2, at 207.

243. John C. Yoo, Choosing Justices: A Political Appointments Process and the Wages of Judicial Supremacy, 98 MICH. L. REV. 1436, 1466 (2000) (reviewing TERRI JENNINGS PERETTI, IN DEFENSE OF A POLITICAL COURT (1999)); $c f$. John O. McGinnis, Justice Without Justices, 16 CoNST. COMMENT. 541, 541 (1999) (proposing the elimination of "the position of Supreme Court Justice"). See generally DAVID ALISTAIR YALOF, PURSUIT OF JUSTICES: PRESIDENTIAL POLITICS AND THE SELECTION OF SUPREME COURT NOMINEES (1999).

244. Robert F. Nagel, Advice, Consent, and Influence, 84 NW. U. L. REV. 858, 860 (1990).

245. Matthew 20:16, 19:30; see also Mark 10:31; Luke 13:30.

246. Compare George Kannar, The Constitutional Catechism of Antonin Scalia, 99 YALE L.J. 1297 (1990) (criticizing the theology implicit in Justice Scalia's jurisprudence) with Michael Stokes Paulsen \& Steffen N. Johnson, Scalia's Sermonette, 72 NOTRE DAME L. REV. 863 (1997) (defending a public display of religious sentiment by Justice Scalia). 
weapons of politics. The ghost of Justice Robert Jackson still haunts the Court's hallowed halls: "The tools belong to the [Justice] who can use them."247 Ironically enough, despite trying his hardest to deny his own counsel, Justice Scalia has said it best. "This is what this [Court] is about. Power."248

247. Youngstown Sheet \& Tube Co. v. Sawyer, 343 U.S. 579, 654 (1952) (Jackson, J., concurring).

248. Morrison v. Olson, 487 U.S. 654, 699 (1988) (Scalia, J., dissenting). 


\section{MATHEMATICAL APPENDIX}

In this appendix we formally define the various voting indices discussed in the text. Let $X$ be the set of Supreme Court Justices. There are three collections of subsets of $X$ that we will use in our analysis. Call a subset of the Justices a coalition if they are exactly the set of Justices that joined some opinion during the relevant time frame. Let $R$ be the collection of coalitions where the number of appearances of a subset in $R$ is equal to the number of different opinions this subset joined. ${ }^{249}$ From $R$ we construct the collection of subsets $O$ by removing all but one of each copy of a coalition. That is, in $R$ the subset $\{1,3,4,5,7\}$ might appear five times but in $O$ it will only appear once. From the collection $O$ we construct the feasible sets, denoted $S C$ by computing all of the intersections of the sets contained in $O$, i.e.,

$$
S C=\left\{A \mid A=O_{1} \cap O_{2} \cap \ldots \cap \mathrm{O}_{k}, O_{i} \in O\right\} .
$$

Let $v$ be the function on subsets of $X$ that identifies the winning coalitions. That is, for each subset $A \subseteq X$,

$$
v(A)=\left\{\begin{array}{lll}
1 & \text { if } & |A| \geq 5 \\
0 & \text { if } & |A| \leq 4
\end{array}\right.
$$

We can now formally define the different indices discussed in the paper. The two indices defined by Baker use the data from $R$. Baker's standard measure, $B S M$, assigns to each justice

$$
B S M(x)=\frac{1}{r} \sum_{\{A \in R \mid x \in A\}} v(A)
$$

where the number $r$ is chosen so that the sum $\sum_{\{x \in X\}} B S M(x)=1$.

249. Thus, technically, $R$ is not a set but a multi-set because elements in it can appear more than once. 
The BSM index counts the number of times that a Justice appeared in the majority. Baker's decision measure, $B D M$, assigns to each justice the index

$$
B D M(x)=\frac{1}{r^{\prime}} \sum_{\{A \in R \mid x \in A\}} v(A)-v(A-x)
$$

where $r$ ' is chosen, again, so that the sum of the indices is 1 . In other words, each Justice is assigned the number of times that she appears in a coalition of size 5 (and then the index is normalized to sum to 1 .)

The next three indices we will define are based on the collection $O$. Our naive index, $N$, is defined by

$$
N(x)=\frac{1}{s} \sum_{\{A \in O \mid x \in A\}} v(A)-v(A-x)
$$

where, again, the $s$ is chosen so that the indices sum to 1 . The only difference between our naive index and Baker's decision measure is that we consider coalitions in $O$ and Baker considers the coalitions in $R$.

The median justice index, $M$, is defined by

$$
M(x)=\frac{1}{t} \sum_{\{A \in O \mid x \in A\}} v(A),
$$

which is the analog to Baker's standard measure, where we only consider the coalitions without multiplicity (and $t$ is chosen to normalize the sum.) Our Banzhaf index, $B$, is defined by

$$
B(x)=\frac{1}{s^{\prime}} \sum_{\{A \in O \mid x \in A \text { and } A-x \in O\}} v(A)-v(A-x)
$$

where $s^{\prime}$ is chosen so that the index sums to 1 . It is easy to see that $B(x)$ counts the number of times that $x$ is in a coalition $A$ contained in $O$ of size 5 and the coalition $A-x$ is also in $O$. The generalized Banzhaf index, $G B$, is defined the same way as $B$ only instead of using the collection $O$ we use $S C$ : 


$$
\left.G B(x)=\frac{1}{S^{\prime \prime}} \sum_{\{A \in S C \mid x \in A \text { and }} v(A-x \in S C\}\right)-v(A-x)
$$

We have encoded the data by assigning to each Justice a number according to seniority, i.e., Chief Justice Rehnquist is assigned 1, Justice Stevens is assigned 2, etc.. The raw data sets R94-R99 are available from the authors. The computations discussed in the paper were performed using scripts in Mathematica which are available from Paul Edelman. 
